\title{
MEIO AMBIENTE E SANEAMENTO BÁSICO: NOVAS PERSPECTIVAS
}

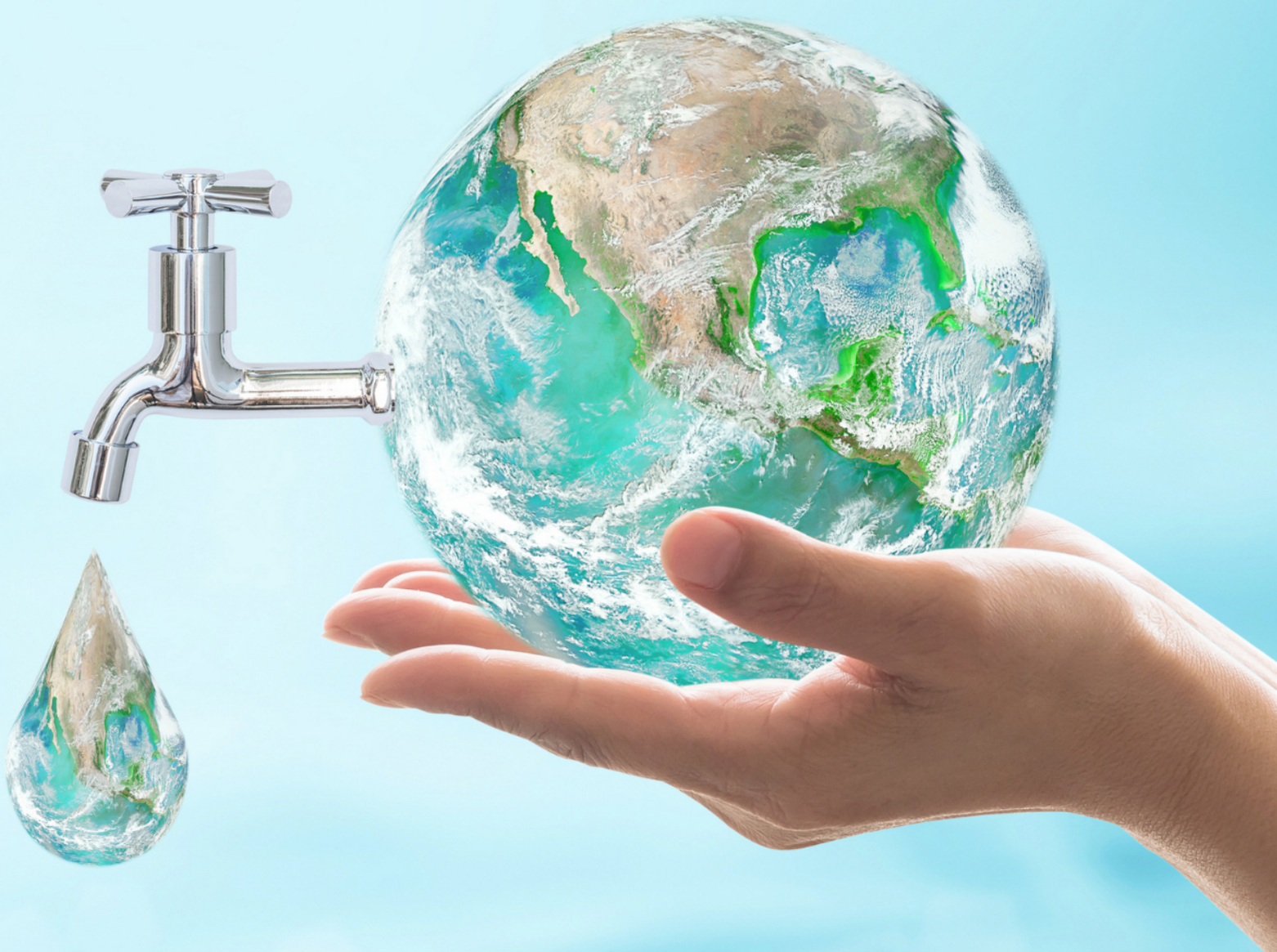

Nayanne Maria Gonçalves Leite

Maria Isabel Ferreira dos Santos

Antônio Rondinelly da Silva Pinheiro

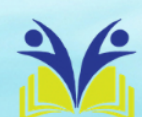


Nayanne Maria Gonçalves Leite

Maria Isabel Ferreira dos Santos

Antônio Rondinelly da Silva Pinheiro

Meio Ambiente e Saneamento básico: novas perspectivas

$1^{\text {a }}$ ed.

Piracanjuba-GO

Editora Conhecimento Livre

Piracanjuba-GO 
$1^{\mathrm{a}} \mathrm{ed}$

\section{Dados Internacionais de Catalogação na Publicação (CIP)}

Leite, Nayanne Maria Gonçalves

L533M Meio Ambiente e Saneamento básico: novas perspectivas

/ Nayanne Maria Gonçalves Leite. Maria Isabel Ferreira dos Santos. Antônio Rondinelly da Silva

Pinheiro. - Piracanjuba-GO

Editora Conhecimento Livre, 2021

90 f.: il

DOI: $10.37423 / 2021 . e d c l 287$

ISBN: 978-65-89955-09-2

Modo de acesso: World Wide Web

Incluir Bibliografia

1. recursos-hídricos 2. resíduos-sólidos 3. tecnologias I. Leite, Nayanne Maria Gonçalves II. Santos,

Maria Isabel Ferreira dos III. Pinheiro, Antônio Rondinelly da Silva IV. Título

CDU: 333.72

https://doi.org/10.37423/2021.edc1287

O conteúdo dos artigos e sua correção ortográfica são de responsabilidade exclusiva dos seus respectivos autores. 


\title{
EDITORA CONHECIMENTO LIVRE
}

\section{Corpo Editorial}

\author{
Dr. João Luís Ribeiro Ulhôa \\ Dra. Eyde Cristianne Saraiva-Bonatto \\ Dr. Anderson Reis de Sousa \\ MSc. Frederico Celestino Barbosa \\ MSc. Carlos Eduardo de Oliveira Gontijo
}

$\underline{\text { MSc. Plínio Ferreira Pires }}$

Editora Conhecimento Livre

Piracanjuba-GO 


\section{SUMÁRIO}

CAPÍTULO 1 5 ESTUDO DO POTENCIAL DE CAPTAÇÃO DE ÁGUAS PLUVIAIS EM ESCOLA RURAL, NO SUL CEARENSE

LUAN ALVES FURTADO

NAYANNE MARIA GONÇALVES LEITE

ALDA VIANA DUARTE

DAMIANA ANDREIA TAVARES SOARES

AIRTON DANILO DE SOUSA OLIVEIRA

DOI 10.37423/210604407

CAPÍTULO 2

ANÁLISE COMPARATIVA DOS SERVIÇOS DE ÁGUA E ESGOTO DE CAJAZEIRAS-PB COM

BASE NOS INDICADORES DE DESEMPENHO DO SNIS

Geraldo Mendes Batista Neto

Alda Viana Duarte

Anaylle Vieira Lacerda de Oliveira

Karen Tayna Fernandes de Almeida Nóbrega

Mayrla Abreu Pinheiro

DOI 10.37423/210704412

CAPÍTULO 3

DIAGNÓSTICO DE POTABILIDADE DA ÁGUA DE CISTERNAS EM COMUNIDADE RURAL DO SUL CEARENSE COM BASE NA AVALIAÇÃO DE PADRÃO FÍSICO-QUÍMICO

LUAN ALVES FURTADO

NAYANNE MARIA GONÇALVES LEITE

DAMIANA ANDREIA TAVARES SOARES

ANTONIO RONDINELLY DA SILVA PINHEIRO

GEORGE DO NASCIMENTO RIBEIRO

GUILHERME RODRIGUES GOMES

MARIA ISABEL FERREIRA DOS SANTOS

DOI 10.37423/210704413

CAPÍTULO 4

SELEÇÃO DE ÁREAS PARA IMPLANTAÇÃO DE ATERRO SANITÁRIO NO MUNICÍPIO DE SÃO JOÃO DO RIO DO PEIXE-PB, UTILIZANDO TÉCNICAS DE GEOPROCESSAMENTO

Wamon Salomão Dantas Torres

Cinthya Santos da Silva

Antonio Rondinelly da Silva Pinheiro

Nayanne Maria Gonçalves Leite

Maria Isabel Ferreira dos Santos

DOI 10.37423/210704414 
CAPÍTULO 5

AVALIAÇÃO DE IMPACTOS AMBIENTAIS CAUSADOS PELA LAGOA DE ESTABILIZAÇÃO NO

BAIRRO VILA NOVA II, NA CIDADE DE CAJAZEIRAS/PB

Álisson Alberto Pinto Tôrres

Nayanne Maria Gonçalves Leite

Guilherme Rodrigues Gomes

Millena Dayse Barbosa da Silva

Luan Alves Furtado

Cinthya Santos da Silva

DOI 10.37423/210704415 


\section{Capítulo 1}

doi $10.37423 / 210604407$

\section{ESTUDO DO POTENCIAL DE CAPTAÇÃO DE ÁGUAS PLUVIAIS EM ESCOLA RURAL, NO SUL CEARENSE}

LUAN ALVES FURTADO

NAYANNE MARIA GONÇALVES LEITE

ALDA VIANA DUARTE

DAMIANA ANDREIA TAVARES SOARES

AIRTON DANILO DE SOUSA OLIVEIRA
INSTITUTO FEDERAL DE EDUCAÇÃO, CIÊNCIA E TECNOLOGIA DA PARAÍBA

UNIVERSIDADE FEDERAL DE CAMPINA GRANDE

INSTITUTO FEDERAL DE EDUCAÇÃO, CIÊNCIAE TECNOLOGIA DA PARAÍBA

INSTITUTO FEDERAL DE EDUCAÇÃO, CIENCIA E TECNOLOGIA DA PARAÍBA

INSTITUTO FEDERAL DE EDUCACÃO, CIÊNCIA E TECNOLOGIA DA PARAÍBA 
Resumo: O semiárido ocupa 12\% do território nacional e é caracterizado por prolongados períodos de estiagem. As cisternas se apresentam como alternativa para mitigação da escassez hídrica. O objetivo deste estudo é analisar o potencial de captação de águas pluviais em uma escola municipal na zona rural de Porteiras-CE. Foram analisados os dados pluviométricos locais, a área de captação e a demanda de água na instituição para determinar se a escola poderia atingir a autossuficiência hídrica através do aproveitamento de águas de chuva. O volume médio estimado para a captação é 1408,1 $\mathrm{m}^{3}$ /ano e a demanda da escola $915 \mathrm{~m}^{3} / \mathrm{ano}$, diante disto, a área de captação na unidade é suficiente para atender sua demanda sendo necessário apenas $65,6 \%$ da área total disponível. O aproveitamento pluvial garante a autossuficiência hídrica na escola, reduzindo a demanda do sistema público e os respectivos custos envolvidos.

Palavras-chave: (Águas pluviais. Aproveitamento. Autossuficiência hídrica.) 


\section{INTRODUÇÃO}

A água é um recurso natural de grande importância no planeta, sendo usada para diversos fins, como no uso doméstico, na agricultura e em indústrias. Reconhecendo-a como recurso vital, a Resolução 64/292, estabelecida através da Organização das Nações Unidas - ONU, determina o Direito Humano Fundamental de acesso à água potável, advindo dos direitos à vida, à dignidade humana, à saúde física e mental e à um padrão de vida adequado.

Os problemas de disponibilidade hídrica afetam inúmeros países, dentre eles o Brasil, que possui uma região semiárida de $969.589 \mathrm{~km}^{2}$ envolvendo os estados do Ceará, Rio Grande do Norte, Paraíba, Pernambuco, Piauí, Alagoas, Sergipe, Bahia e Minas Gerais (CORREIA et al., 2011). As regiões semiáridas apresentam como características principais a aridez do clima, a deficiência hídrica e a insuficiência de precipitações pluviométricas, que acarretam um prolongado período seco anual e elevam a temperatura local, caracterizando a aridez sazonal (FUNASA, 2019). Deste modo, a gestão de águas no Brasil é realizada através de medidas legais que regulam o seu acesso e visam a proteção deste recurso.

A Lei brasileira de número 9.433, de 8 de janeiro de 1997, que institui a Política Nacional de Recursos Hídricos, possui fundamentos baseados na determinação de que a água é um recurso natural limitado e um bem de domínio público. Em seus objetivos, propõe assegurar as gerações atuais e futuras a disponibilidade deste recurso em quantidade suficiente e qualidade adequada, sendo perceptível o reconhecimento de sua relevância frente a outros recursos naturais, bem como a indispensável garantia do seu acesso (BRASIL, 1997). Deste modo, a lei prevê o acesso a água como um direito de todos os cidadãos do país.

Embora a água seja definida como um bem de domínio público, dados apresentados através do Plano Nacional de Saneamento Básico - PLANSAB, em sua revisão para o ano de 2019, mostra que, da população brasileira, $57,7 \%$ dos habitantes possuem abastecimento de água potável, 39,6\% possuem atendimento precário e $2,7 \%$ da população não possui nenhum meio de atendimento (BRASIL, 2019). Deste modo, é possível inferir que, mesmo após uma década, os avanços quanto a implantação de mecanismos de acesso a água potável pelos brasileiros não atingiu sua integralidade, como propõe a Lei 11.445, de 5 de janeiro de 2007, instituída como marco legal do saneamento brasileiro (BRASIL, 2007). 
No aspecto social, pode-se afirmar que o alcance por parte da população à medidas de saneamento tem forte impacto sobre a diminuição das desigualdades de acesso a educação no país. Segundo relatório de 2018 da Unicef intitulado "Pobreza na infância e na adolescência", 24,8\% das crianças e dos adolescentes no Brasil vivem uma privação do saneamento, e a principal consequência decorrente deste problema é a defasagem na sua educação. O relatório também concluiu que os jovens do campo sofrem mais privações do que aqueles que vivem nas áreas urbanas e que a região Nordeste apresentou o segundo maior índice de privação do acesso a água por parte da população (UNICEF, 2018).

Uma das perspectivas que corroboram com o déficit no acesso democrático à água encontra-se fortemente atrelada a intensificação da distribuição prioritária de água potável aos centros urbanos em detrimento às pequenas cidades, periferias urbanas e áreas rurais (REZENDE; HELLER, 2008). No entanto, é importante ressaltar que a presença de redes de distribuição em comunidades rurais apresentou aumento sistemático passando de 9\%, em 1991, para 28\% em 2010 (INFOSANBAS, 2010). Os dados retratam um novo cenário caracterizado por uma inversão do assistencialismo público na área rural, que passa a ser assistida mais ativamente pelo governo por meio de políticas públicas de saneamento, no entanto, estes mesmos dados ainda chamam atenção para os desafios da universalização do acesso democrático ao saneamento.

Embora existam no semiárido as fontes alternativas atuando como reservas hídricas em períodos de escassez, como os açudes, o ciclo hidrológico natural representa uma ameça as quantidades volumétricas nesses reservatórios, a incidência solar e percolação no solo favorecem a diminuição desse volume ao longo do tempo. É importante evidenciar também os problemas advindos da falta de controle quanto a exposição da água a agentes patogênicos, que muitas vezes são capazes de comprometer a segurança hídrica da água e atuam como agravante dos problemas de saúde pública em comunidades que dependem unicamente deste tipo de reserva hídrica.

Avanços técnicos como o surgimento de tecnologias para o aproveitamento de águas de chuva, e sua aplicação no semiárido nordestino brasileiro, contribuiu com o amortecimento dos impactos causados pelos longos períodos de estiagem, a limitação de reservas hídricas e o déficit de políticas públicas para acesso a sistemas de abastecimento de água convencionais.

Os reservatórios, comumente chamados de cisternas, acumulam as águas precipitadas durante os perídos de chuva e atuam como fonte do recurso em períodos cuja pluviometria é baixa. Estes dispositivos reduzem os índices de evaporação da água devido ao feixo hermético, além disso, dado o 
volume limitado que podem armazenar e a possibilidade de higienização, o controle químico, físico e microbiológico da água pode ser monitorado com maior facilidade, garantindo segurança hídrica aos seus usuários.

As cisternas podem ser enxergadas como uma alternativa para a compensação dos efeitos de ordem geográfica e da falta de assistencialismo público à população. Dada a relevância destes sistemas no enfrentamento da escassez hídrica e sua importância social, o presente estudo investiga o potencial de captação de águas de chuva em uma escola de comunidade rural da cidade de Porteiras, localizada no sul cearense, com vista a proposição de implementação desses sistemas como alternativa para a garantia de autossuficiência hídrica da instituição.

\section{FUNDAMENTAÇÃO TEÓRICA}

De acordo com o INSA - Instituto Nacional do Semiárido (2013), o semiárido brasileiro se estende por grande parte de 8 estados do nordeste também pelo norte de Minas Gerais, totalizando 1135 municípios que correspondem a $12 \%$ do território nacional, onde vivem $11,85 \%$ dos habitantes do país, $62 \%$ em área urbana e $38 \%$ em área rural.

O semiárido possui características particulares como pluviometria média anual inferior a $800 \mathrm{~mm}$, índice de aridez de até 0,5 e risco de seca, ou prolongamento da estação seca, maior que 60\% (INSA, 2013). Embora a limitação dos recursos hídricos no Nordeste seja a principal causa para a escassez, abordagens como as de Tugoz et al. (2017), apontam para o recente agravamento deste problema, decorrente da cultura do desperdício de água potável.

Embora a densidade de ocupação do semiárido seja bastante difusa, os direitos legais entre os cidadãos devem ser interpretados de maneira gereralizada. No entanto, a limitação do acesso a políticas públicas motivou um processo de êxodo e superlotação das cidades, conforme observa Menezes et al. (2013, p. 460):

"O contexto histórico, político e socioeconômico do semiárido, caracterizado por apresentar baixo nível de sustentabilidade hídrica em decorrência da precipitação pluviométrica, demonstram que durante muito tempo, a seca foi considerada como principal fator que provocava as precárias condições de vida dos sertanejos, levando os a intensificar o processo de êxodo rural que ainda perdura no interior da região Nordeste."

O consequente crescimento populacional e a expansão dos usos múltiplos são responsáveis pelo aumento da demanda de água potável, motivando a busca por meios alternativos que visem a sua reutilização (CAMARA et al., 2019). 
Os sistemas de captação de águas de chuva, por conseguinte, podem ser vistos como tecnologia apropriada na redução do consumo de água tratada e medida estratégica para o desenvolvimento social e econômico da região semiárida, dada sua simplicidade, viabilidade e baixo custo (MENEZES et al., 2013; LIMA et al., 2017).

De acordo com Camara et al. (2019, p. 11), " um sistema de captação de água pluvial possui boa relação de custo - benefício, sendo um aliado contra a escassez, além de promover a redução no custo de aquisição de água potável e garantir a sustentabilidade a todo o sistema". As perspectivas positivistas quanto a implementação destes sistemas são reforçadas quando confrontadas com políticas assistencialistas promovidas pelo governo.

Segundo Silva et al. (2019), existem no Brasil e no mundo diferenciadas pesquisas e programas relacionados a implantação de sistemas de aproveitamento de águas pluviais. No Nordeste, a Articulação Semiárido Brasileiro (ASA), desenvolve projetos de grande vulto, como 'Um Milhão de Cisternas', 'Cisternas nas Escolas' entre outros, que visam a melhoria da convivência com o semiárido, propiciando o acesso a água durante os períodos de estiagem (ASA, 2020). O projeto Cisternas nas Escolas, contempla unidades rurais em nove estados, com a construção de cisternas de 52 mil litros em cada unidade, com vista a garantia da água durante o ano letivo. Outra medida de governo de grande relevância é o Programa Água para Todos, que já instalou mais 800 mil cisternas rurais no país (BRASIL, 2019).

Tugoz et al. (2017) destacam que a decisão de instalar cisternas para a captação e uso da água da chuva em escolas favorece a utilização economicamente eficiente e socialmente justa dos recursos hídricos, ao mesmo tempo que estimula nos alunos uma consciência voltada à sustentabilidade e preservação ambiental, possibilita o pleno funcionamento deste espaço, independente do enfrentamento de períodos de escassez.

Tugoz et al. (2017, p. 28), ainda faz menção, dentro do contexto de sustentabilidade ambiental, sobre a capacidade de difusão social de uma consciência ambiental que a escola seria capaz de atingir, conforme se pode observar:

\footnotetext{
"A escola passa a ser considerada um espaço propício ao desenvolvimento de ações voltadas para a educação ambiental, uma vez que pode promover nos educandos uma busca contínua pelo equilíbrio entre homem e natureza, e instigá-los a disseminar esse conhecimento voltado à sustentabilidade".
}

Nesse contexto, a decisão de instalar cisternas para a captação e uso da água da chuva em escolas atua como uma ferramenta de apoio para a conscientização frente ao aproveitamento de recursos 
hídricos e o enfrentamento da deficiência hídrica experimentada por regiões como as do nordeste brasileiro, enquanto promove a formação de agentes de mudanças e multiplicadores de ações sustentáveis.

\section{METODOLOGIA}

O presente estudo foi desenvolvido em uma unidade escolar do Sítio Muquém, com coordenadas geográficas de referência $7^{\circ} 32^{\prime} 31.5^{\prime \prime S} 39^{\circ} 02^{\prime} 04.6^{\prime \prime} \mathrm{W}$, no município de Porteiras - CE. A cidade possui uma área territorial de $217,6 \mathrm{~km}^{2}$, seu clima é tropical quente semiárido brando, com temperatura média de $25^{\circ} \mathrm{C}$, pluviosidade média de $904,2 \mathrm{~mm}$, com período chuvoso de janeiro a abril e uma população de 15.061 habitantes (IPECE, 2016).

A escola Professora Beatriz Pinheiro da Costa localiza-se a 9,7 km da sede do município, dispõe de 13 salas de aula e uma área construída de aproximadamente $2300 \mathrm{~m}^{2}$. Oferta os ensinos infantil e fundamental, funcionando nos turnos matutino e vespertino. Sua capacidade total é de 450 alunos e a unidade conta com um quadro de 41 servidores.

Os dados técnicos foram reunidos mediante consulta a prefeitura municipal de Porteiras e a coordenação da unidade escolar localizada na zona rural do município.

O levantamento das áreas de captação foi realizado com a aquisição da planta arquitetônica bem como através da observação visual com o uso de ferramentas disponíveis no software Google Earth e seguiu as orientações da ABNT NBR 10844 - Instalações prediais de águas pluviais. O consumo médio de água foi estimado mediante o uso de dados de volume consumido durante o período letivo de 2019, informados pelo SISAR nas faturas mensais do referente ano.

O volume de captação teórico, utilizado para mensurar o volume pluvial aproveitável, depende do coeficiente de escoamento superficial da cobertura, além de características como índice de absorção, perdas por porosidade do material utilizado na cobertura, evaporação, calhas e dutos com vazamentos, ineficiência no processo de captação, bem como da eficiência do sistema de descarte do escoamento inicial, para que ocorra a retirada de impurezas que escoam junto da água em direção ao reservatório durante eventos de precipitação (ABNT, 2007; LEITE; SANTOS, 2015; BEZERRA et al., 2010; CANDINE et al., 2019).

O volume de água de chuva aproveitável foi estimado mediante a seguinte equação $V=P \times A \times C \times$ $\eta$, contida na ABNT NBR 15527/2019, onde V é o volume de água aproveitável; P é a precipitação; A é a área de coleta; C é o coeficiente de Runoff e $\eta$ é o fator que representa a eficiência do sistema de 
captação (ABNT, 2019). É válido salientar que o coeficiente de Runoff (C), geralmente admite valor aproximado a 0,95, enquanto o fator de captação $(\eta)$ varia de 0,5 a 0,9, um valor prático estimado para $C \times \eta$, quando não se têm dados suficientes através de processo investigativo in loco, durante a utilização dos sistemas de descarte (TOMAZ, 2010).

A intensidade pluviométrica foi calculada com base na série histórica 2011 - 2020, levantada pela Fundação Cearense de Meteorologia e Recursos Hídricos (FUNCEME) para o município de Porteiras.

Os resultados obtidos reúnem a capacidade de captação pela unidade através das coberturas, bem como a demanda por parte da comunidade escolar, considerando o uso múltiplo para fins potáveis e não potáveis, como higienização da escola, produção de refeições, dessedentação humana e irrigação para o cultivo de plantas frutíferas nas dependências da instituição.

\section{RESULTADOS E DISCUSSÃO}

A água consumida na unidade é oriunda do sistema de abastecimento público que atende a comunidade local e é gerida pelo Sistema Integrado de Saneamento Rural (SISAR). Os valores decorrentes do consumo de água na unidade são repassadas diretamente a prefeitura municipal da cidade que arca com essas despesas com parte do orçamento público destinado à gestão do município.

A unidade de ensino conta com dois reservatórios para abastecimento da unidade. O reservatório inferior é feito em concreto armado e localiza-se no subsolo, conta com um conjunto motor bomba para elevação da água, sua capacidade total de armazenamento é de 10 mil litros, sendo abastecido pela rede pública. O reservatório superior possui $1 / 5$ da capacidade de armazenamento do inferior e é fabricado em alvenaria estrutural. Deste modo, o volume útil total, quando disponível $100 \%$ da capacidade de armazenamento na escola, corresponde a 12 mil litros.

De acordo com os dados levantados junto a coordenação da escola, os problemas relativos a falta d'água são recorrentes na instituição. Conforme avaliou-se, o consumo diário para usos múltiplos, o racionamento de água na rede pública e a limitação dos horários de distribuição na rede em detrimento do volume do reservatório são incompatíveis, não há capacidade suficiente para garantir a água por mais de 3 dias na instituição. Este problema incorre diretamente no funcionamento da unidade, implicando no cancelamento de aulas.

A figura 1 demonstra a parcela de consumo diário em detrimento do volume total, considerando a capacidade máxima de ocupação do edifício e um consumo médio de $10 \mathrm{~L}$ por pessoa em um único dia de serviço na unidade. 
Figura 1 - Oferta e disponibilidade hídrica na escola

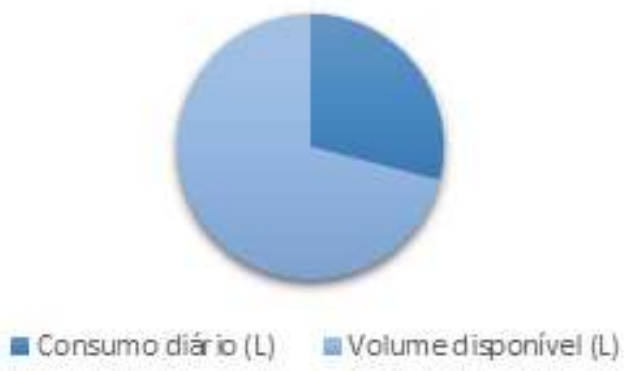

Fonte: autores (2020)

É possível inferir que, quando comparado ao valor correspondente a disponibilidade hídrica da escola, a instituição teria condições de funcionamento com abastecimento pleno de água durante apenas dois dias, dado que o consumo diário representa 40,91\% do volume total dos reservatórios.

A partir dos dados da série pluviométrica foi possível elaborar pluviograma médio mensal do período, compreendido entre 2011 e 2020 para a localidade (Fig. 2).

Figura 2 - Pluviograma da cidade de Porteiras Ceará

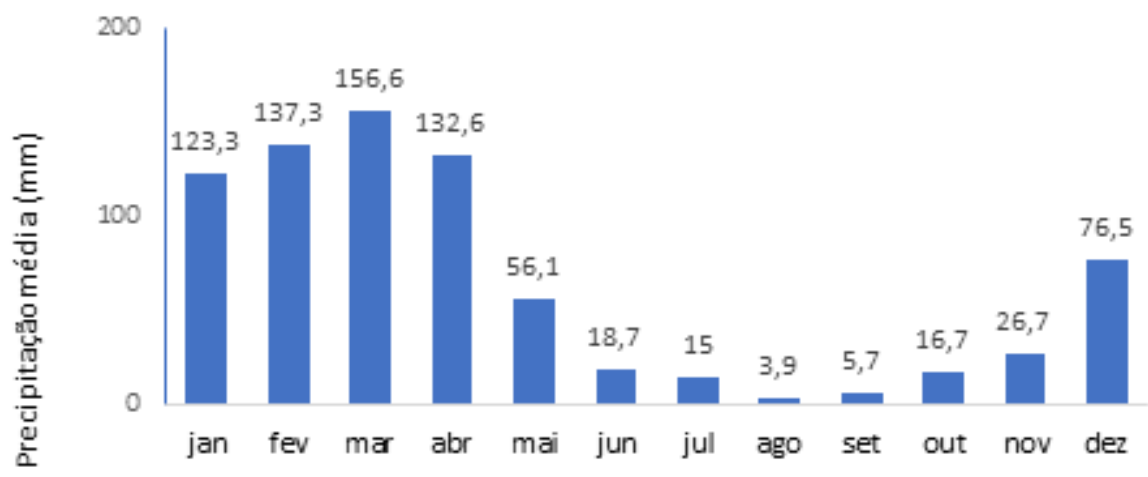

Fonte: autores (2020)

Observa-se irregularidade da distribuição das chuvas ao longo do ano, como é esperado para a região semiárida. A máxima precipitação para o município pode ser observada no mês de março e mínima em agosto, com média de 64,1 mm. Também é possível observar que durante seis meses do ano, o volume médio de chuvas não chega a atingir $50 \mathrm{~mm}$ e em quatro deles ultrapassa os $100 \mathrm{~mm}$.

As áreas de captação foram levantadas, conforme exibe o Quadro 1. Estas foram calculadas conforme orienta a ABNT NBR 10844/1989, considerando os incrementos devidos à inclinação das coberturas, que variaram entre $25 \%$ e $40 \%$. A área de telhados compreende $2.288,5 \mathrm{~m}^{2}$, dividida em sete blocos 
entre salas de aula, direção, refeitório e biblioteca, com telhas cerâmicas e uma quadra poliesportiva com cobertura metálica.

Tabela 1 - Levantamento de áreas de contribuição por bloco

\begin{tabular}{|c|c|c|c|c|c|c|}
\hline Bloco & $\mathbf{C}(\mathbf{m})$ & L. 1 (m) & L.2 (m) & i $(\%)$ & Área $\left(\mathbf{m}^{2}\right)$ & Descrição \\
\hline 1 & 39,3 & 5,1 & 5,1 & 25 & 411,17 & 4 salas de aula, diretoria, cantina, $2 \mathrm{WC}$ \\
\hline 2 & 16,3 & 4,5 & 4,5 & 25 & 149,53 & 1 Sala de aula, 1 sala de informática \\
\hline 3 & 18,0 & 3,5 & 3,5 & 25 & 129,88 & 2 salas de aula, 2 banheiros, 1 depósito \\
\hline 4 & 17,0 & 2,9 & 2,9 & 25 & 100,46 & 1 sala de aula, 3 banheiros \\
\hline 5 & 18,5 & 3,4 & 3,4 & 25 & 129,67 & 1 sala de aula, 1 sala, 1 biblioteca \\
\hline Quadra & 33,1 & 13,0 & 13,0 & 40 & 926,89 & 1 quadra poliesportiva coberta \\
\hline 6 & 24,8 & 3,3 & 3,3 & 30 & 168,30 & 1 Refeitório, 1 cozinha, 1 depósito \\
\hline 7 & 38,4 & 3,4 & 3,4 & 30 & 272,62 & 4 salas de aula, 2 banheiros \\
\hline
\end{tabular}

Fonte: autores (2020)

O volume médio de água consumido pela escola corresponde a aproximadamente $76,3 \mathrm{~m}^{3} / \mathrm{mês}$, com base na média aritmética do consumo de janeiro a dezembro do ano de 2019 , totalizando um volume de $915 \mathrm{~m}^{3}$ /ano. Esse valor representa o consumo de água para usos múltiplos pela unidade, conforme descrito na metodologia do presente trabalho.

O presente estudo admitiu, para o levantamento de volume de captação, um coeficiente de Runnof de 0,95 , considerando o bom estado de conservação do material cerâmico utilizado na cobertura dos blocos bem como da cobertura metálica. Além disso, o valor resitante admitido obtenção da expressão $C \times \eta$ corresponde a 0,80 .

Deste modo, os resultados obtidos para os dados coletados e analisados podem ser observados na figura 3, que mostra, em azul o potencial de captação utilizando toda a área dos telhados, e em laranja utilizando apenas $1500 \mathrm{~m}^{2}$, ou seja, $65,6 \%$ da área total, suficiente para acumular todo o volume médio estimado como demanda para o ano letivo, com base na média de consumo mensal, para o ano de 2019, pela instituição. 
Figura 3 - Pluviometria média do município de Porteiras - CE

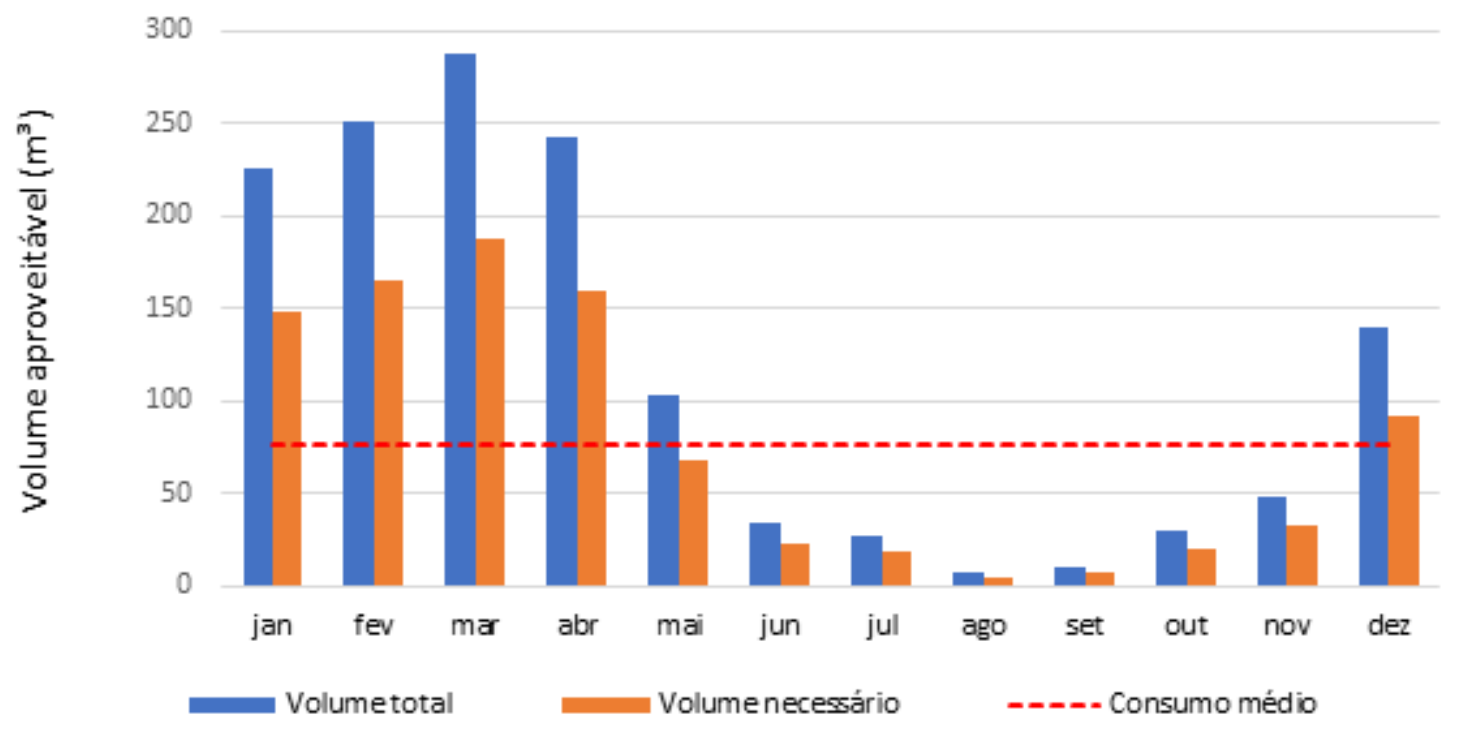

Fonte: autores (2020)

Nos meses de maio a novembro observa-se que a pluviometria decresce, de tal modo que é insuficiente para suprir o consumo escolar de $76,25 \mathrm{~m}^{3} / \mathrm{mês}$. O acúmulo de $39,62 \%$ do volume total de água consumida pela unidade deve acontecer nos meses de maior pluviometria, entre janeiro e abril, de modo a assegurar a autossuficiência hídrica durante o ano letivo escolar e compensar os efeitos do período de seca experimentados durante os demais meses do ano, quando não será possível reabastecer o reservatório.

Comparando a atual disponibilidade de água dentro da instituição por meio de reservatório abastecido pelo sistema público local com a oferta hídrica mediante a captação e reserva de águas pluviais, entende-se haver sustentabilidade para abastecimento da comunidade escolar em sua totalidade, mesmo sem a complementação por meio do reservatório pré existente.

É válido salientar que a escola dispõe de aproximadamente $2000 \mathrm{~m}^{2}$ de área livre, conforme estimativa realizada através de sensoriamento remoto, com o uso do Google Earth. Essa área localiza-se próxima aos blocos de salas de aula, e poderia ser utilizada para a implantação dos reservatórios, para armazenamento da água captada.

\section{CONSIDERAÇÕES FINAIS/ CONCLUSÃO}

Diante da demanda de água para usos múltiplos envolvendo fins potáveis e não potáveis na escola, a instalação de um sistema de captação de águas pluviais, conforme apresentado ao longo deste estudo, 
se mostra um método vantajoso e sustentável considerando os aspectos de autossuficiência hídrica. Além disso, a implantação de dispositivos de captação de águas de chuva representa um melhor aproveitamento dos recursos hídricos disponíveis na região.

A instalação destes sistemas oportuniza a possibilidade de gerar uma consciência ecológica na unidade, através do aproveitamento deste recurso, e consequente diminuição dos gastos públicos com água na instituição, podendo este estudo viabilizar a difusão da ideia de aproveitamento de águas de chuva em outras unidades escolares locais do município, como uma alternativa para o enfrentamento da estiagem na região, e redução de eventuais prejuízos ao ano letivo escolar.

Através dos resultados obtidos, é possível observar que a escola possui uma área de captação suficientemente grande sendo necessária apenas $1500 \mathrm{~m}^{2}$ do total, superando a margem demandada para o consumo anual, dispensando a captação de águas de chuva em parte dos blocos de salas de aula da instituição.

A pluviosidade exibe valores acima do consumo médio mensal da escola e o acúmulo de água durante os meses de maior oferta compensam os meses de baixa pluviosidade, garantindo volume suficiente para as demandas de água durante todo o ano letivo escolar.

É importante relatar que o aproveitamento das águas de chuva para fins potáveis envolve a adoção de sistemas de descarte de águas iniciais, além de cuidados com a higienização, inspeção e manutenção periódica dos reservatórios, áreas de captação e calhas, além do controle físico, químico e microbiológico da água por ele reservada, que também deverá ser realizado periodicamente, a fim de reduzir quaisquer riscos de contaminação por doenças de veiculação hídrica.

A implementação de um sistema de captação de águas de chuva envolve a necessidade de investimentos públicos, bem como o dimensionamento de infraestrutura adequada para o local, de modo a facilitar sua implementação e gestão, tais assuntos são de suma relevância, podendo motivar estudos futuros. 


\section{REFERÊNCIAS BIBLIOGRÁFICAS}

ABNT - ASSOCIAÇÃO BRASILEIRA DE NORMAS TÉCNICAS. NBR 10844: Instalações prediais de águas pluviais - Procedimento. Rio de Janeiro: ABNT, 1989. 13 p.

ABNT - ASSOCIAÇÃO BRASILEIRA DE NORMAS TÉCNICAS. NBR 15527: Aproveitamento de água de chuva de coberturas para fins não potáveis - Requisitos. Rio de Janeiro: ABNT, 2019. 10 p.

ASA - ARTICULAÇÃO NO SEMIÁRIDO BRASILEIRO (ed.). Sobre nós: História. 2020. Disponível em: https://www.asabrasil.org.br/sobre-nos/historia. Acesso em: 29 agosto 2020.

BEZERRA, S. M. C.; CHRISTIAN, P.; TEIXEIRA, C. A.; Farahbakhsh, K. Dimensionamento de reservatório para aproveitamento de água de chuva: comparação entre métodos da ABNT NBR 15527:2007 e Decreto Municipal 293/2006 de Curitiba, PR. Revista Ambiente Construído, Porto Alegre, v.10, n.4, p.219-231, 2010.

BRASIL. Lei no 9.433, de 8 de janeiro de 1997. Institui a Política Nacional de Recursos Hídricos, cria o Sistema Nacional de Gerenciamento de Recursos Hídricos, [...]. Diário Oficial da União: seção 1, Brasília, DF, 09 jan. 1997.

BRASIL. Lei no 11.445, de 5 de janeiro de 2002. Estabelece as diretrizes nacionais para o saneamento básico, [...]. Diário Oficial da União: seção 1, Brasília, DF, 08 jan. 2007.

BRASIL. Ministério do Desenvolvimento Regional. Plano Nacional de Saneamento Básico: Versão revisada - 2019. Brasília, DF, 07 março. 2019. p. 226. Disponível em: <https://www.cidades.gov.br/images/stories/ArquivosSNSA/Arquivos_PDF/plansab/Versaoatualizad a07mar2019_consultapublica.pdf>. Acesso em: 04 fev. 2020.

BRASIL. Ministério do Desenvolvimento Regional. Água para Todos. Disponível em: https://www.mdr.gov.br/contato/317-secretaria-nacional-de-programas-urbanos/agua-paratodos/6076-agua-para-todos. Acesso em: mai. 2020.

CAMARA, C. D. et al. Potencial de captação de água da chuva no Colégio Estadual do Campo Dom Pedro II no município de São Miguel do Iguaçu - Paraná. Brazilian Journal of Animal and Environmental Research, v.2, n.4, p.1464-1472, 2019.

CANDIDE, P. F.; BELÉM JÚNIOR, J. S. Aproveitamento de água de chuva para fins não potáveis - Estudo de caso: Bairro social Reny Cury. Revista Espacios, v.38, n.46, p.18-30, 2017.

CORREIA, R. C et al. A região semiárida brasileira. In: VOLTOLINI, T. V. (Ed.). Produção de caprinos e ovinos no Semiárido. Petrolina: Embrapa Semiárido, 2011. p. 21-48.

FUNASA - Fundação Nacional de Saúde. Manual de Saneamento. 5.ed. Brasília, DF: FUNASA,2019.

FUNCEME - Fundação Cearense de Meteorologia e Recursos Hídricos. Calendário de chuvas no Estado do Ceará. 2020. Disponível em:

http://www.funceme.br/app/calendario/produto/municipios/media/anual?data=2009-1-1. Acesso em: 28 maio 2020. 
INFOSANBAS. Abastecimento de água. 2010. Disponível em:

https://infosanbas.org.br/artigos/abastecimento-de-agua/. Acesso em: 10 mar. 2020.

INSA - Instituto Nacional do Semiárido (ed.). O semiárido brasileiro: riquezas, diversidades e saberes. Campina Grande, PB: INSA, 2013. Disponível

em:https://portal.insa.gov.br/images/acervocartilhas/O\%20Semi\%C3\%A1rido\%20brasileiro\%20rique zas\%20diversidades\%20e\%20saberes.pdf. Acesso em: 28 maio 2020.

IPECE (Instituto de Pesquisa e Estratégia Econômica do Ceará) Perfil Municipal. 2007. Disponível em: http://www2.ipece.ce.gov.br/atlas/capitulo1/12/129.htm. Acesso em: 30 jan. 2020.

LEITE, P. A.; SANTOS, I. F. S. Dimensionamento preliminar de reservatório de águas pluviais para o prédio do instituto de recursos naturais (Irn-Unifei). Revista Brasileira de Energias Renováveis, v.4, n.4, p.42-52, 2015.

LIMA, J. A et al. Potencial da economia de água potável pelo uso de água pluvial: análise de 40 cidades da Amazônia. Engenharia Sanitária e Ambiental, v.16, n.3, p.291-298, 2011.

LIMA, K. L. B. A. et al. Análise da viabilidade de implantação de captação de águas pluviais em escola pública no Recife - PE. Revista Nacional de Gerenciamento de Cidades, v.5, n.38, p.1-17, 2017.

MENEZES, G. F. F et al. Indicadores de qualidade, manejo e uso da água pluvial armazenada em cisternas do semiárido baiano. Revista Agrarian, v.6, n.22, p.460-472, 2013.

RESENDE, S. C.; HELLER L. O saneamento no Brasil: políticas e interfaces. Belo Horizonte: UFMG Escola de Engenharia, 2008.

SILVA, C. R. et al. Análise técnica e econômica da captação e uso de águas pluviais em uma edificação com diferentes tipos de coberturas. Revista Brasileira de Gestão Ambiental e Sustentabilidade, v.6, n.14, p.911-930, 2019.

TUGOZ, J. E.; BERTOLINI, G. R. F.; BRANDALISE, L. T. Captação e aproveitamento da água das chuvas: o caminho para uma escola sustentável. Revista de Gestão Ambiental e Sustentabilidade, v.6, n.1, p.2639, 2017.

TOMAZ, P. Água: pague menos. São Paulo: Plínio Tomaz, 2010. 135 p. ISBN 978-85-905933-7-9.

UNICEF - FUNDO DAS NAÇÕES UNIDAS PARA A INFÂNCIA. Pobreza na infância e na adolescência. UNICEF. Brasil, p. 1-20. 13 ago. 2018. Disponível em:

https://www.unicef.org/brazil/media/156/file/Pobreza_na_Infancia_e_na_Adolescencia.pdf. Acesso em: 10 set. 2020. 


\section{Capítulo 2}

doi) $10.37423 / 210704412$

\section{ANÁLISE COMPARATIVA DOS SERVIÇOS DE ÁGUA E ESGOTO DE CAJAZEIRAS-PB COM BASE NOS INDICADORES DE DESEMPENHO DO SNIS}

Geraldo Mendes Batista Neto

Alda Viana Duarte

Anaylle Vieira Lacerda de Oliveira

Karen Tayna Fernandes de Almeida Nóbrega

Mayrla Abreu Pinheiro
Instituto Federal de Educação, Ciência e

Tecnologia da Paraíba Campus Cajazeiras

Instituto Federal de Educação, Ciência e

Tecnologia da Paraíba Campus Cajazeiras

Instituto Federal de Educação, Ciência e

Tecnologia da Paraíba Campus Cajazeiras

Instituto Federal de Educação, Ciência e

Techologia da Paraíba Campus Cajazeiras

Instituto Federal de Educação, Ciência e

Tecnologia da Paraíba Campus Cajazeiras 
Resumo: Este artigo se propõe a analisar a evolução na prestação dos serviços de água e esgoto da cidade de Cajazeiras, entre os anos de 2014 e 2018, com base em indicadores do Sistema Nacional de Informações em Saneamento (SNIS). Realizou-se a comparação dos dados obtidos com valores do estado da Paraíba, da região nordeste e do Brasil. Uma triagem foi realizada nos indicadores de forma a serem escolhidos buscando considerar a relevância nos serviços de saneamento e aqueles de simples compreensão, possibilitando uma comparação de desempenho com clareza. Após a coleta dos dados, para uma melhor visualização e comparação, foram elaborados gráficos correspondentes a cada indicador. Assim, com os resultados dos gráficos gerados, foi discorrido uma análise comparativa dos indicadores e as suas respectivas localidades.

Palavras-chave: Indicadores de desempenho. SNIS. Análise comparativa. 


\section{INTRODUÇÃO}

Conforme Vieira e Babtista (2008), a universalização de serviços de abastecimento público de água, além do saneamento das águas residuais urbanas, e da gestão dos resíduos sólidos urbanos, se caracterizam como indicadores de qualidade de vida e bem-estar social. Porém, dados do Sistema Nacional de Informação sobre o Saneamento - SNIS (2018) informam que apenas 53\% dos brasileiros têm acesso à coleta de esgoto, ou seja, quase 100 milhões de cidadãos não têm acesso a este serviço.

Paralelamente, a porcentagem de municípios com serviço de esgotamento sanitário é de 60,3\%, ou seja, boa parcela da população brasileira ainda sofre as consequências da falta de saneamento básico, este sendo de fundamental importância e necessidade nas suas residências (SNIS, 2018) e que, quando inexistente, pode alterar o equilíbrio do ecossistema do ambiente onde a descarga for realizada de forma irregular (BUITRAGO et al., 2015), além das águas residuais se constituírem como uma ameaça às comunidades (GONZÁLEZ et. al, 2019) e responsável pelo surgimento de doenças que possuem relação direta com as más condições da água e saneamento (YAHYA; PULE; CHUMA, 2017). Nesse contexto, Rossoni et. al (2020) alertam que tal setor requer um importante aperfeiçoamento nos modelos de gestão, por ser pouco valorizado, porém de grande impacto social.

Quando se fala em abastecimento de água, 83,62\% da população brasileira é atendida com o abastecimento de água tratada. Em números, a situação é um pouco melhor, entretanto, na distribuição da água para consumo, os sistemas sofrem perdas que corroboram em uma média nacional de 38,45\% (SNIS, 2018), ou seja, um total de 7,1 mil piscinas olímpicas de água potável são perdidas diariamente (ITB, 2020). Assim, como mencionam Sobrinho e Borja (2016), no Brasil, os sistemas de abastecimento de água persistem em apresentar perdas de água e baixa eficiência energética e, reforçando, Lopes et. al (2015) afirmam que os problemas não estão relacionados somente à cobertura, mas também tem relação direta com a eficiência do serviço.

Nesse contexto, afunilando-se a análise para a região Nordeste, tais índices são ainda mais alarmantes: apenas $36,24 \%$ do esgoto da região é tratado. Em relação ao abastecimento de água, ele acontece para $74,21 \%$ da população, e as perdas chegam a 45,98\% (SNIS,2018), demonstrando que a realidade brasileira está longe de ser a ideal, e que isto tende a se agravar em regiões mais interioranas do país. Nesse sentido, Dias, Raiol e Nonato (2017) discorrem que o processo de urbanização afeta o contingente populacional mais pobre em relação ao acesso de serviços públicos básicos, como o saneamento. Naha el tal (2019) afirmam que é uma tendência brasileira e de outros países o déficit 
mais elevado, em relação ao acesso, especialmente ao esgotamento sanitário, nas áreas rurais. Ainda, Griesinger et al (2002) relatam que serviços de saneamento e o abastecimento de água potável são uns dos principais problemas nestas áreas economicamente carentes.

Portanto, é de fundamental importância o conhecimento de tais indicadores de desempenho para que haja um fortalecimento da gestão em concessionárias, especialmente em regiões tendenciosas a situações ainda mais graves com saneamento básico, como as mais afastadas das capitais: a exemplo da cidade de Cajazeiras, localizada no estado da Paraíba, e que é objeto de estudo do presente artigo.

Neste cenário, as decisões políticas em qualquer dos setores da economia são capazes de produzir mudanças no bem-estar da sociedade (TUDELA-MAMANI; LEOS-RODRÍGUEZ, 2018 apud URIBE et al, 2003). Logo, a criação da Lei no 11.445 em 2007, que estabelece diretrizes nacionais para o saneamento básico, trouxe várias alterações importantes no âmbito das companhias de saneamento, tornando obrigatório a regulação sobre os prestadores de serviço, além de incentivar a melhoria do seu desempenho por meio da institucionalização do uso de indicadores (COSTA et al., 2013; SPERLING e SPERLING, 2013).

A utilização de indicadores de desempenho tem grande relevância na avaliação da qualidade dos serviços prestados, sua repercussão, e na definição de metas de melhoria e ampliação dos serviços de saneamento básico (RASERA et al., 2017; SOUSA et al., 2012). Sob o ponto de vista da gestão pública, o monitoramento de dados e informações é importante e necessário para que se possa acompanhar o progresso e os impactos de cada ação, como também contribui com a transparência na prestação de contas (LOPES et al., 2016; NIRAZAWA e OLIVEIRA, 2018); sendo que, de acordo com Alegre et al. (2006), o objetivo principal de qualquer sistema de indicadores de desempenho é fornecer informações ou conjunto de dados que possam ser utilizados com a finalidade de auxiliar na tomada de decisões. Ainda, traduzem de forma sintética os aspectos mais relevantes, permitindo assim constituir um sistema mais claro, racional e transparente (HELLER et al., 2009; LOPES et al., 2016; SPERLING, 2013; VIEIRA e BAPTISTA, 2008).

Nessa conjuntura, o Sistema Nacional de Informações em Saneamento (SNIS) se constitui como o maior e mais importante banco de dados do setor de saneamento brasileiro, criado pelo governo federal em 1996, passando este a ter grande destaque com a instituição do Sistema Nacional de Informações de Saneamento Básico (SINISA), criado através da Lei n 11.445/2007 (COSTA et al.,2013; SOUZA et al., 2012). Tal sistema será a base de dados para levantamento de informações acerca dos 
indicadores de desempenho nacional, da região Nordeste, estado da Paraíba e do município de Cajazeiras.

Logo, o presente artigo tem como objetivo analisar a evolução na prestação dos serviços de água e esgoto da cidade de Cajazeiras/PB, entre os anos de 2014 e 2018, com base em indicadores do Sistema Nacional de Informações em Saneamento (SNIS), promovendo uma comparação dos dados obtidos com valores da Paraíba, da região Nordeste e do Brasil.

\section{METODOLOGIA}

O monitoramento da eficiência e da qualidade dos serviços de saneamento, assim como a transparência das operações estabelecidas, são alguns dos principais objetivos da aplicação dos indicadores de desempenho, que proporcionam a composição de dados que podem ser comparados e avaliados, gerando dessa forma diagnósticos que são ferramentas úteis para facilitar os processos de tomada de decisões dentro das companhias, e além disso, permitem a análise em paralelo dos resultados fornecidos pelos prestadores.

As informações acerca dos indicadores escolhidos na abordagem deste artigo são provenientes do Sistema Nacional de Informações sobre Saneamento (SNIS). Esse sistema, consolidado como o maior banco de dados nacional, é administrado na esfera federal e fornece informações de caráter institucional, administrativo e operacional sobre a prestação de serviços de água, de esgotos e de manejo de resíduos sólidos (COSTA et al., 2013).

A seleção dos indicadores foi feita buscando considerar a relevância nos serviços de saneamento, assim como uma descrição clara que pudesse dispensar análises de difícil compreensão, tornando possível o entendimento dos resultados inclusive para aqueles que não dispõem de aprofundados conhecimentos técnicos sobre saneamento. Na tabela 1 abaixo estão listados os indicadores escolhidos, assim como a classificação destes dentro do banco de dados do SNIS, seus respectivos códigos e unidades de análise: 
Tabela 1: Indicadores selecionados

\begin{tabular}{|c|c|c|c|c|c|c|}
\hline \multicolumn{3}{|c|}{$\begin{array}{l}\text { INDICADORES OPERACIONAIS - } \\
\text { ÁGUA }\end{array}$} & \multicolumn{3}{|c|}{$\begin{array}{l}\text { INDICADORES OPERACIONAIS - } \\
\text { ESGOTO }\end{array}$} & \multirow{2}{*}{$\begin{array}{c}\text { INDICADORES } \\
\text { SOBRE } \\
\text { QUALIDADE } \\
\\
\text { Incidência das } \\
\text { análises de } \\
\text { coliformes totais } \\
\text { fora do padrão }\end{array}$} \\
\hline $\begin{array}{l}\text { Índice de } \\
\text { atendimento } \\
\text { total de água }\end{array}$ & $\begin{array}{c}\text { Índice de } \\
\text { consumo de } \\
\text { energia elétrica } \\
\text { em sistemas de } \\
\text { abastecimento } \\
\text { de água }\end{array}$ & $\begin{array}{c}\text { Índice de } \\
\text { perdas na } \\
\text { distribuição }\end{array}$ & $\begin{array}{l}\text { Índice de } \\
\text { coleta de } \\
\text { esgoto }\end{array}$ & $\begin{array}{l}\text { Índice de } \\
\text { esgoto } \\
\text { tratado } \\
\text { referido à } \\
\text { água } \\
\text { consumida }\end{array}$ & $\begin{array}{l}\text { Índice de } \\
\text { consumo de } \\
\text { energia } \\
\text { elétrica em } \\
\text { sistemas de } \\
\text { esgotamento } \\
\text { sanitário }\end{array}$ & \\
\hline percentual & $\mathrm{kWh} / \mathrm{m} 3$ & percentual & percentual & percentual & $\mathrm{kWh} / \mathrm{m}^{3}$ & percentual \\
\hline IN055 & IN058 & IN049 & IN015 & IN046 & IN059 & IN084 \\
\hline
\end{tabular}

Fonte: Sistema Nacional de Informações sobre Saneamento (SNIS).

A análise dos dados obtidos foi feita buscando realizar uma comparação entre os valores nacionais, da região Nordeste, do estado da Paraíba e da cidade de Cajazeiras-PB.

Para considerar os resultados de maneira mais ampla, buscou-se informações de um intervalo de 5 anos, de 2014 a 2018. Como o SNIS apresenta uma defasagem de aproximadamente dois anos entre a divulgação dos dados e o ano de ocorrência, 2018 era o período mais atualizado.

Vale destacar que o SNIS não coleta indicadores, mas sim informações primárias (ou seja, as variáveis das fórmulas) que são autodeclaradas pelas companhias, e a partir dessas informações o sistema realiza os cálculos através de expressões matemáticas específicas para cada indicador (SNIS, 2018a).

Os indicadores totalizados por agrupamentos - região, estado, total da amostra, etc. - são calculados pela somatória das informações do grupo, e não como média dos valores (SNIS, 2018a). Isso quer dizer, por exemplo, que o resultado de um indicador a nível nacional não é calculado a partir da média entre os estados, mas a partir da somatória das informações fornecidas por cada prestador no país. Dessa forma, para cada informação componente do indicador, são somados os valores correspondentes a cada um dos prestadores de serviços do grupo em pauta e então processado o cálculo do indicador. Em decorrência dessa forma de cálculo, o processamento dos indicadores totais considera somente os prestadores de serviços que apresentam todas as informações necessárias para o cálculo e desconsidera as entidades que apresentarem dados indisponíveis (SNIS, 2018a). 


\section{RESULTADOS}

\section{IN055 - ÍNDICE DE ATENDIMENTO TOTAL DE ÁGUA}

As variáveis e o cálculo para este indicador, como demonstrado em SNIS (2018b), são indicados na na formulação abaixo:

$$
\begin{aligned}
& \text { Índice de atendimento } \\
& \text { total de água }
\end{aligned}=\frac{\left(\begin{array}{c}
\text { População total atendida } \\
\text { com abastecimento de água }
\end{array}\right)}{\left(\begin{array}{c}
\text { População total residente do }(s) \\
\text { município }(s) \text { com abastecimento de água }
\end{array}\right)}
$$

Onde, pela definição do SNIS (2018c), temos que:

- População total atendida com abastecimento de água: Valor da população total atendida com abastecimento de água pelo prestador de serviços, no último dia do ano de referência.

- População total residente do(s) município(s) com abastecimento de água: valor da soma das populações totais residentes (urbanas e rurais) . Inclui tanto a população beneficiada quanto a que não é beneficiada com os serviços. Não deve ser confundida com a população total atendida com abastecimento de água.

Com este indicador, podemos ter uma noção geral do atendimento de água a toda população que é de fundamental importância para o gerenciamento de diversos fatores que envolvem o abastecimento de água.

\section{ANÁLISE COMPARATIVA SEGUNDO O IN055}

Gráfico 1: Índice de atendimento total de água

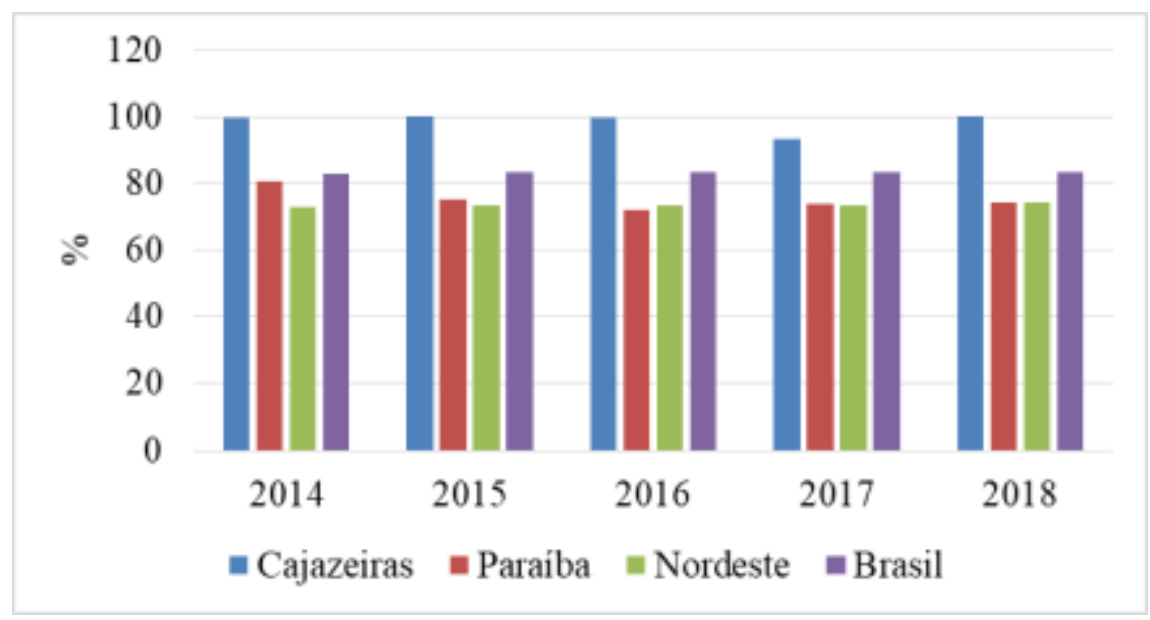

Fonte: Autores, 2020 
Para este indicador, a cidade de Cajazeiras possui uma ótima porcentagem de atendimento total de água, demonstrando que praticamente cem por cento de sua população é atendida durante todos esses anos. O Brasil mantém-se estável durante todos os anos, não existindo oscilações durante o período avaliado. Praticamente o mesmo acontece com o estado da Paraíba e a região Nordeste, oscilações mínimas ocorrem durante os anos considerados. O que podemos observar para todas as localidades, é que não ocorreu nenhum tipo de queda, mantiveram-se estáveis durante todo esse tempo. Portanto, pode ser analisado de maneira positiva, visto que não houve queda, porém também podemos verificar que não houve nenhum tipo de preocupação com a ampliação do atendimento para as localidades que ainda sofrem com a falta de abastecimento de água.

\section{IN058 - ÍNDICE DE CONSUMO DE ENERGIA ELÉTRICA EM SISTEMAS DE ABASTECIMENTO DE ÁGUA}

As variáveis e o cálculo para este indicador, como demonstrado em SNIS (2018b), são indicados na formulação abaixo:

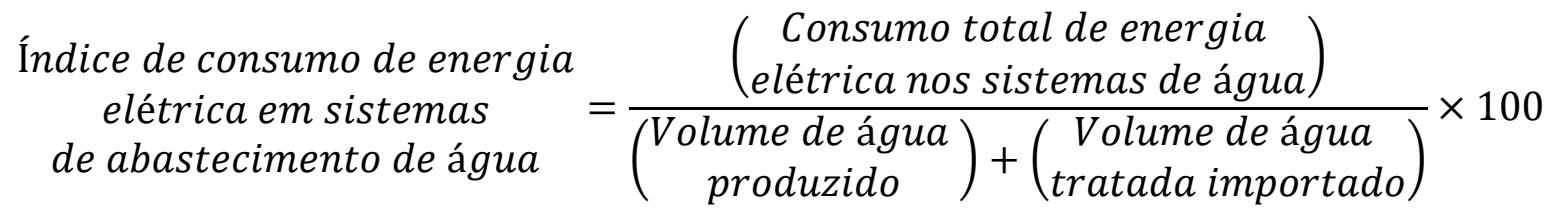

Onde, pela definição do SNIS (2018), temos que:

- Consumo total de energia elétrica nos sistemas de água: Quantidade anual de energia elétrica consumida nos sistemas de abastecimento de água, incluindo todas as unidades que compõem os sistemas.

- Volume de água produzido: Volume anual de água disponível para consumo, compreendendo a água captada pelo prestador de serviços e a água bruta importada. Inclui também os volumes de água captada pelo prestador de serviços ou de água bruta importada, que sejam disponibilizados para consumo sem tratamento.

- Volume de água tratada importado: Volume anual de água potável, previamente tratada, recebido de outros agentes fornecedores.

\section{ANÁLISE COMPARATIVA SEGUNDO O IN058}

Gráfico 2: Índice de consumo de energia elétrica em sistemas de abastecimento de água 


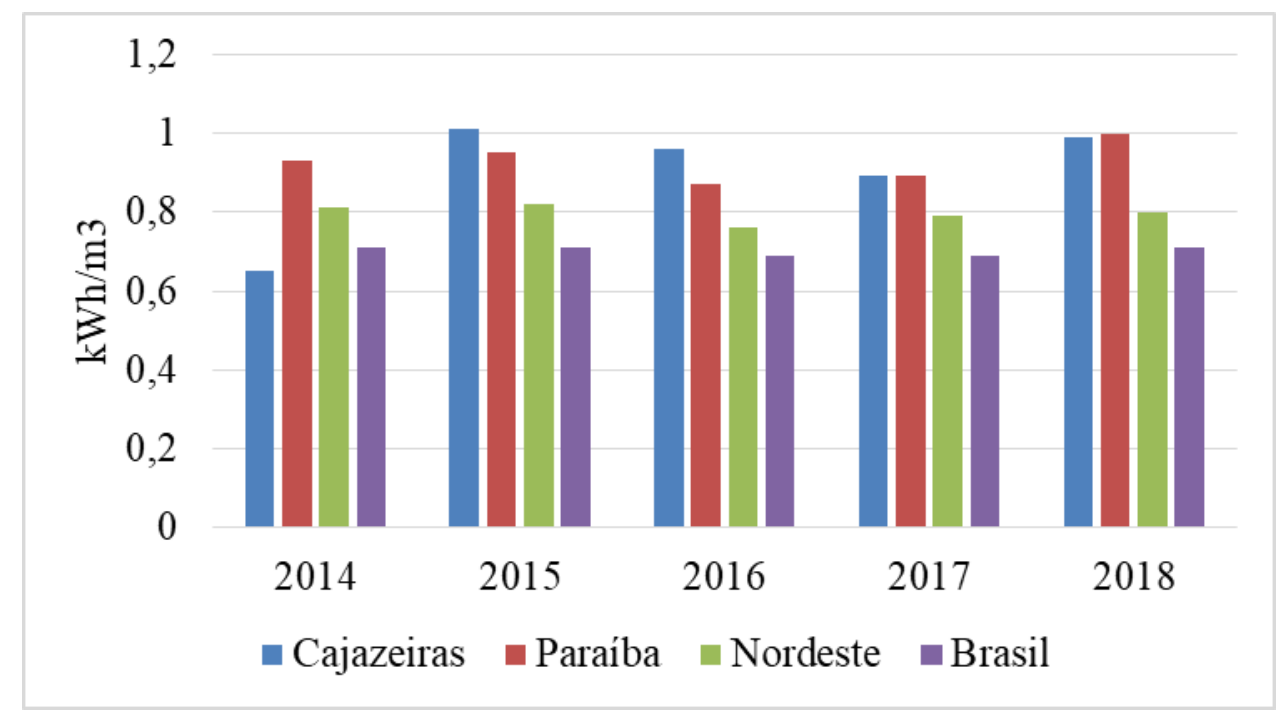

Fonte: Autores, 2020

É possível observar que a cidade em estudo apresentou o menor índice, em relação a todas as regiões comparadas, no ano de 2014. Isto pode ser citado como uma característica benéfica para a cidade, onde houve uma economia de energia para o suporte do seu sistema de abastecimento de água, em ao próprio estado, que inclusive apresentou o maior índice e, consequentemente, da região Nordeste e nacionalmente. Já para o ano seguinte, a situação foi invertida: a quantidade de $\mathrm{kw} / \mathrm{m}^{3}$ consumida apresentou-se acima dos valores regionais e, inclusive, bem acima do consumo nacional; havendo pouca variação até o ano de 2016. Para o ano de 2017, seu consumo foi igualado ao estado da Paraíba, porém apresentando-se acima do índice regional e também nacional, o que pode ocasionar maior gasto e afetar a situação financeira da concessionária. Por fim, para o ano de 2018, houve um aumento em conjunto com o estado da Paraíba, em relação aos índices regional e nacional, sendo um fator negativo em termos quantitativos e qualitativos.

\section{IN049 - ÍNDICE DE PERDAS NA DISTRIBUIÇÃO}

As variáveis e o cálculo para este indicador, como demonstrado em SNIS (2018b), são indicados na formulação abaixo:

$$
\underset{\text { Índice de perdas }}{\text { na distribuição }}=\frac{\left(\begin{array}{c}
\text { Volume de água } \\
\text { produzido }
\end{array}\right)+\left(\begin{array}{c}
\text { Volume de água } \\
\text { tratada importado }
\end{array}\right)-\left(\begin{array}{c}
\text { Volume de água } \\
\text { consumido }
\end{array}\right)-\left(\begin{array}{c}
\text { Volume de } \\
\text { serviço }
\end{array}\right)}{\left(\begin{array}{c}
\text { Volume de água } \\
\text { produzido }
\end{array}\right)+\left(\begin{array}{c}
\text { Volume de água } \\
\text { tratada importado }
\end{array}\right)-\left(\begin{array}{c}
\text { Volume de } \\
\text { serviço }
\end{array}\right)} \times 100
$$

Onde, pela definição do SNIS (2018c), temos que: 
- Volume de água produzido: Volume anual de água disponível para consumo, compreendendo a água captada e a água bruta importada.

- Volume de água tratada importado: Volume anual de água potável, previamente tratada em ETA(s), recebido de outros agentes fornecedores.

- Volume de água consumido: Volume anual de água consumido por todos os usuários acrescido do volume de água tratada exportado para outro prestador de serviços.

- Volume de serviço: Valor da soma dos volumes anuais de água usados para atividades operacionais e especiais, acrescido do volume de água recuperado.

É importante ressaltar que a qualidade das informações utilizadas no cálculo deste indicador depende substancialmente de dois fatores: macromedição e hidrometração, onde o primeiro mensura os volumes produzidos nas unidades de tratamento de água, enquanto o segundo mede os volumes consumidos pelos usuários. Caso os prestadores não contem com procedimentos precisos de medição, seus volumes e consequentemente suas perdas serão apenas estimados, sendo que as estimativas reduzem consideravelmente a confiabilidade dos dados (COSTA et al., 2013).

\section{ANÁLISE COMPARATIVA SEGUNDO O IN049}

Gráfico 3: Índice de perdas na distribuição

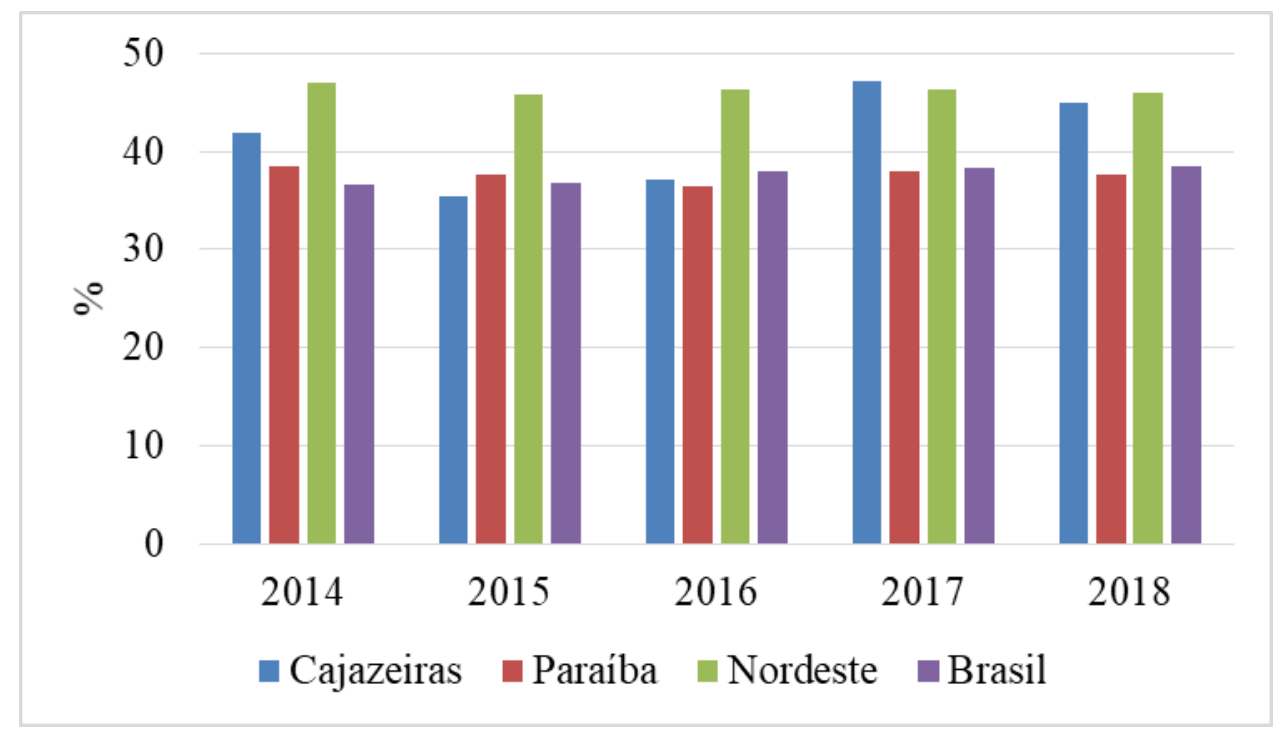

Fonte: Autores, 2020.

Diante destes dados, percebe-se que a cidade de Cajazeiras apresenta em três cenários uma média superior a nacional, enquanto que em 2015 e 2016 se mostra com índices de perda mais baixos. 
Comparada aos dados regionais, Cajazeiras apresenta menores valores, o que representa condições positivas no abastecimento em relação ao Nordeste. No entanto, comparando tais índices aos relativos à Paraíba, a cidade apresenta valores acima da média do estado, equivalente a 37,63\%, em três anos distintos, voltando a aproximar-se deste valor no ano de 2016. De modo geral, Cajazeiras apresenta uma média de $41,30 \%$ em perdas, dado bastante preocupante, o que demanda a necessidade de medidas corretivas e de gestão para diminuição destes valores.

\section{IN015 - ÍNDICE DE COLETA DE ESGOTO}

As variáveis e o cálculo para este indicador, como demonstrado em SNIS (2018b), são indicados na formulação abaixo:

$$
\begin{gathered}
\text { Índice de coleta } \\
\text { de esgoto }
\end{gathered}=\frac{\left(\begin{array}{c}
\text { Volume de esgoto } \\
\text { tratado }
\end{array}\right)}{\left(\begin{array}{c}
\text { Volume de } \\
\text { água consumido }
\end{array}\right)-\left(\begin{array}{c}
\text { Volume de } \\
\text { tratada exportado }
\end{array}\right)} \times 100
$$

Onde, pela definição do SNIS (2018c), temos que:

- Volume de esgotos coletado: Volume anual de esgoto lançado na rede coletora, não inclui volume de esgoto bruto importado.

- Volume de água consumido: Volume anual de água consumido por todos os usuários acrescido do volume de água tratada exportado para outro prestador de serviços.

- Volume de água tratada exportado: Volume anual de água potável, previamente tratada em $\operatorname{ETA}(\mathrm{s})$, transferido para outros agentes distribuidores.

Em geral o volume de esgoto tratado é considerado como sendo de $80 \%$ a $85 \%$ do volume de água consumido. É importante distinguir que nem todo volume de esgoto coletado chega a ser tratado. 
Gráfico 4: Índice de coleta de esgoto

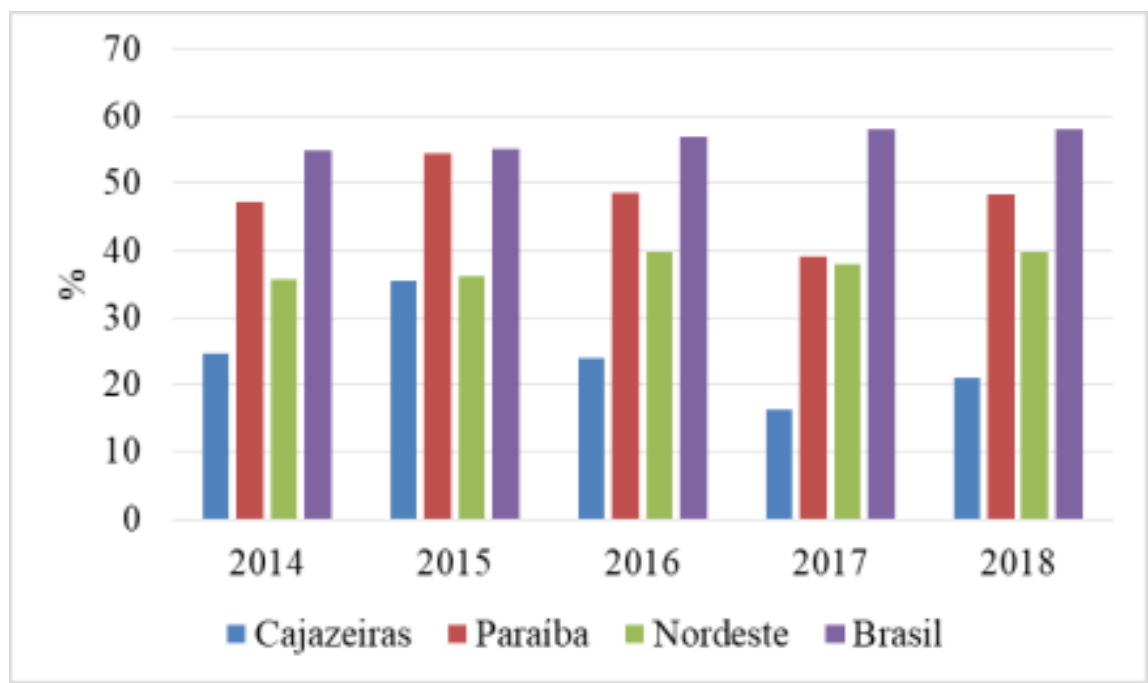

Fonte: Autores, 2020

Constata-se, mediante a análise dos dados, uma situação extremamente preocupante para a cidade de Cajazeiras em detrimento dos níveis nacional, regional e estadual. O valor médio para índice de coleta de esgoto equivale a $24,31 \%$, enquanto o estado da Paraíba possui um valor superior a $47 \%$ em média, diante disso Cajazeiras pode ser considerada uma das cidades que contribuem com baixos valores em tal categoria. É importante ressaltar que a média municipal equivale a menos da metade dos valores nacionais e que a média do estado da Paraíba supera aqueles referentes ao Nordeste, que possui um índice de 37,85\%.

\section{IN046 - ÍNDICE DE ESGOTO TRATADO REFERIDO À ÁGUA CONSUMIDA}

As variáveis e o cálculo para este indicador, como demonstrado em SNIS (2018b), são indicados na formulação abaixo:

$\begin{aligned} & \text { Índice de es goto tartado } \\ & \text { referido à água consuida }\end{aligned}=\frac{\left(\begin{array}{c}\text { Volume de esgoto } \\ \text { tratado }\end{array}\right)+\left(\begin{array}{c}\text { Volume de esgoto bruto exportado } \\ \text { tratado nas instalações do importador }\end{array}\right)}{\left(\begin{array}{c}\text { Volume de } \\ \text { água consumida }\end{array}\right)-\left(\begin{array}{c}\text { Volume de água } \\ \text { exportado }\end{array}\right)}$

Onde, pela definição do SNIS (2018c), temos que:

- Volume de esgoto tratado: Volume anual de esgoto coletado na área de atuação do prestador de serviços e que foi submetido a tratamento, medido ou estimado na(s) entrada(s) da(s) $\mathrm{ETE}(\mathrm{s})$. 
- Volume de esgoto bruto exportado tratado nas instalações do importador: Volume de esgoto bruto que é transferido para outro(s) agente(s) e que foi submetido a tratamento, medido ou estimado na(s) entrada(s) da(s) ETE(s).

- Volume de Água Consumida: Volume anual de água consumido por todos os usuários, compreendendo o volume medido e um volume estimado para as ligações desprovidas de hidrômetro ou com hidrômetro parado, acrescido do volume de água tratada exportado.

- Volume de água exportado: Volume anual de água potável, previamente tratada, transferido para outros agentes distribuidores.

A escolha desse indicador ao invés do tradicional Índice de tratamento de esgoto (IN016) utilizado pelo PLANSAB (2013) é justificada pelo fato de que o IN046 é mais representativo da realidade, apresentando menores distorções. Para uma melhor compreensão, considere a seguinte suposição: se for tratado todo o esgoto de um município que coleta apenas $2 \%$ do total gerado pela população, o índice de tratamento de esgoto para esse município será de $100 \%$, quando na realidade $98 \%$ do esgoto produzido nem sequer chega na estação de tratamento (COSTA et al., 2013).

Isso acaba gerando uma falsa impressão de eficiência quanto ao tratamento do esgoto que, na realidade, é consequência de uma baixa quantidade coletada. Como o IN046 é calculado com base no volume de água consumida, essa distorção é suavizada.

\section{ANÁLISE COMPARATIVA SEGUNDO O IN046}

Gráfico 5: Índice de esgoto tratado referido à água consumida

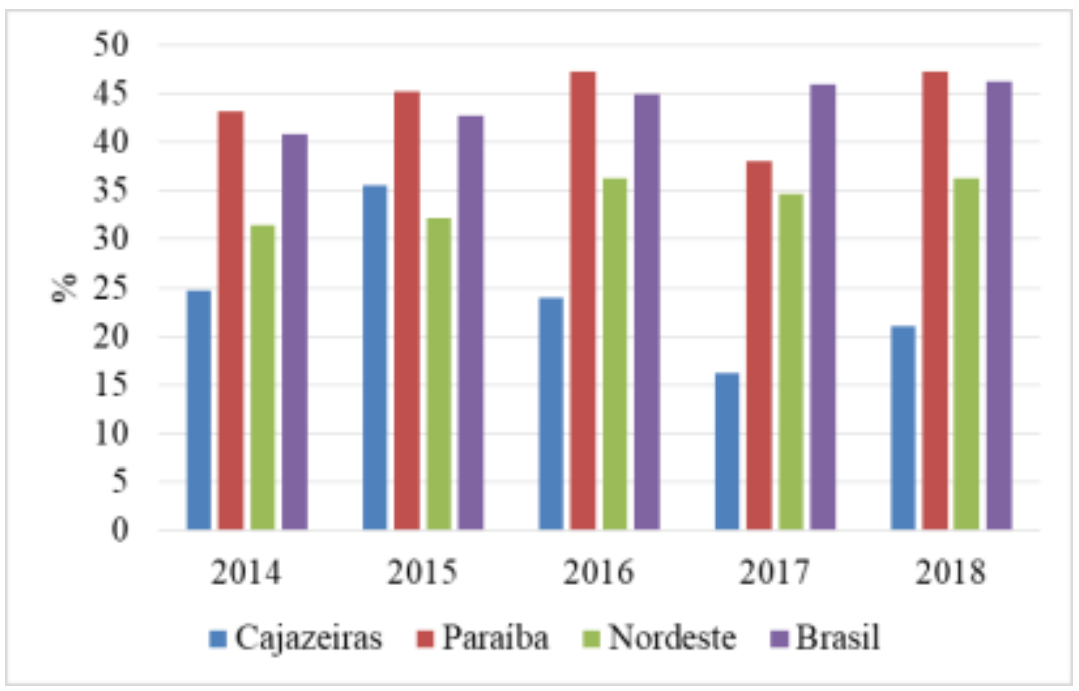

Fonte: Autores, 2020 
Para esse indicador, o estado da Paraíba apresentou resultados que conseguiram se equiparar e até ultrapassar (em 2016 e 2018) os valores nacionais. Os números para a região nordeste como um todo, entretanto, tiveram valores sempre abaixo dos resultados nacionais. A cidade de Cajazeiras, em específico, obteve um pico no ano de 2015 onde conseguiu se colocar acima da região nordeste, no entanto, nos anos seguintes apresentou os valores mais baixos em relação ao restante das regiões analisadas.

\section{IN059 - ÍNDICE DE CONSUMO DE ENERGIA ELÉTRICA EM SISTEMAS DE ESGOTAMENTO SANITÁRIO}

As variáveis e o cálculo para este indicador, como demonstrado em SNIS (2018b), são indicados na formulação abaixo:

$$
\begin{gathered}
\text { Índice de consumo de energia } \\
\text { elétrica em sistemas } \\
\text { de esgotamento sanitário }
\end{gathered}=\frac{\left(\begin{array}{c}
\text { Consumo total de energia elétrica } \\
\text { nos sistemas de esgotos }
\end{array}\right)}{\left(\begin{array}{c}
\text { Volume de esgotos } \\
\text { coletado }
\end{array}\right)}
$$

Onde, pela definição do SNIS (2018c), temos que:

- Consumo total de energia elétrica nos sistemas de esgoto: É a quantidade anual de energia elétrica consumida por todas as unidades que compõem o sistemas de esgotamento sanitário.

- Volume de esgoto coletado: É o volume anual de esgoto lançado na rede coletora. Em geral, é considerado como sendo de $80 \%$ a $85 \%$ do volume de água consumido.

\section{ANÁLISE COMPARATIVA SEGUNDO O IN059}

Gráfico 6: Índice de consumo de energia elétrica em sistemas de esgotamento sanitário

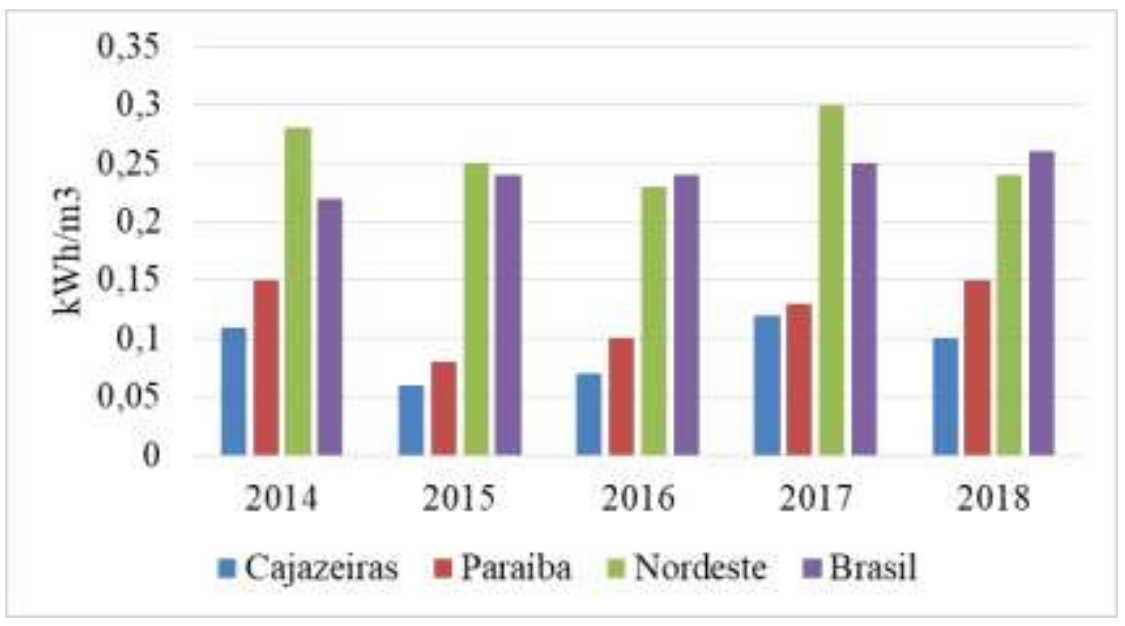

Fonte: Autores, 2020 
Sobre o indicador em questão analisado, é possível observar que o município de Cajazeiras apresentou consumo de energia elétrica menor que o estado da Paraíba, da região nordeste e do Brasil em todos os anos, isso é um ótimo indício de que o município apresenta menores custos operacionais. No ano de 2015 o índice do município reduziu quase pela metade, passando de 0,11 para 0,06 kWh/m³ nos anos de 2016 e 2017 o consumo de energia elétrica passou a aumentar e somente em 2018 apresentou uma nova redução. A Paraíba apresenta consumo menor em todos os anos quando comparado a âmbito regional e nacional. Já a região nordeste apresenta consumo maior em quase todos os anos, exceto 2016 e 2018, isso até mesmo quando comparado a âmbito nacional.

\section{IN084 - INCIDÊNCIA DAS ANÁLISES DE COLIFORMES TOTAIS FORA DO PADRÃO}

As variáveis e o cálculo para este indicador, como demonstrado em SNIS (2018b), são indicados na formulação abaixo:

$$
\left(\begin{array}{c}
\text { Incidência das análises de } \\
\text { coliformes totais fora } \\
\text { do padrão }
\end{array}\right)=\frac{\left(\begin{array}{c}
\text { Quantidade de amostras para } \\
\text { coliformes totais analisadas }
\end{array}\right)}{\left(\begin{array}{c}
\text { Quantidade de amostras para } \\
\text { coliformes totais fora do padrão }
\end{array}\right)} \times 100
$$

Onde, pela definição do SNIS (2018c), temos que:

- Quantidade de amostras para coliformes totais analisadas: Quantidade total anual de amostras coletadas na(s) saída(s) da(s) unidade(s) de tratamento e no sistema de distribuição de água (reservatórios e redes), para aferição do teor de coliformes totais.

- Quantidade de amostras para coliformes totais com resultados fora do padrão: Quantidade total anual de amostras coletadas na(s) saída(s) da(s) unidade(s) de tratamento e na rede de distribuição de água, para aferição do teor de coliformes totais, cujo resultado da análise ficou fora do padrão determinado pela Portaria 2.914/2011 do Ministério da Saúde.

Com base neste indicador pode-se verificar a porcentagem de amostras analisadas de coliformes totais que estão fora do padrão recomendado pela Portaria do Ministério da Saúde № 2.914/2011. A existência de bactérias do grupo coliforme em água potável é considerada como um indicador de contaminação fecal diretamente ligado ao tratamento inadequado ou ineficiência no processo de desinfecção residual da água tratada. Desta forma, quanto menor for o percentual de amostras analisadas de coliformes totais fora do padrão, melhor será a qualidade da água fornecida. 


\section{ANÁLISE COMPARATIVA SEGUNDO O IN084}

Gráfico 7: Incidência das análises de coliformes totais fora do padrão

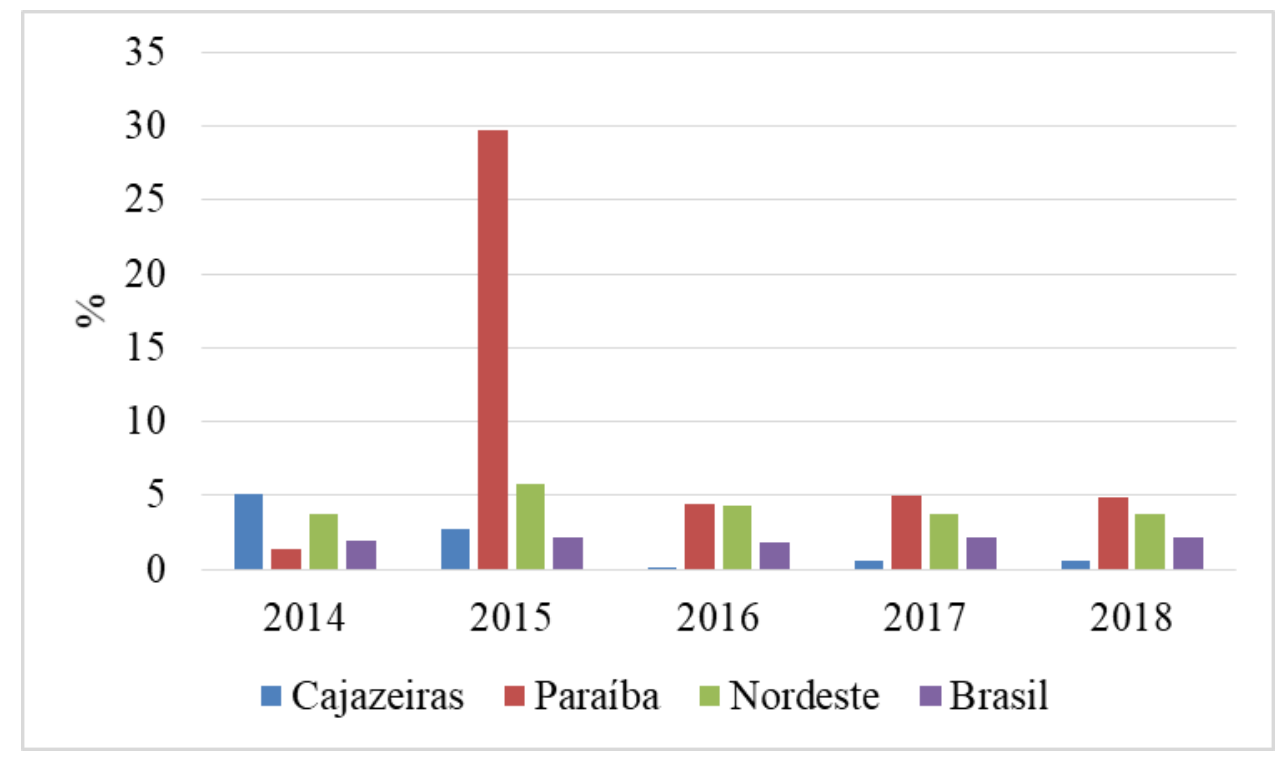

Fonte: Autores, 2020

Para esse indicador, a cidade de Cajazeiras apresentou melhores resultados do que a Paraíba, Nordeste e Brasil exceto no ano de 2014 e mantendo-se próxima no ano de 2015 com os valores nacionais. A Paraíba apresentou no ano de 2015 um valor discrepante em relação a todos os anos e as demais localidades, chegando a quase $30 \%$ e fugindo completamente do aceitável, que está em torno de até 5\%, segundo a Portaria 2.914/2011 do Ministério da Saúde. Visto que durante esse ano de 2015 a Paraíba teve esse pico, isso ocasionou em um pequeno aumento também na porcentagem do Nordeste, que acabou ultrapassando os 5\%. Portanto, exceto esse ano atípico de 2015 para a Paraíba, os demais anos e localidades atenderam ao aceitável permanecendo entre 0 e $5 \%$ de coliformes totais fora do padrão.

\section{CONSIDERAÇÕES FINAIS}

Indicadores são medidas quantitativas da eficiência e da eficácia de uma instituição gestora e que com elas é possível estabelecer parâmetros e avaliar o desempenho da sua qualidade. É de fundamental importância para alcançar metas e para tomada de decisões junto aos gestores. Com base nisso, a presente pesquisa realizou uma análise comparativa do município de Cajazeiras, com a Paraíba, a região Nordeste e Brasil, de indicadores de desempenho, sendo 4 deles relacionados aos serviços de água e 3 relacionadas aos serviços de esgotamento sanitário, com dados do SNIS de 2014 a 2018. 
As informações apontam que o município de Cajazeiras/PB apresenta excelentes resultados em termos de atendimento total de água, com média nos últimos 5 anos de 98,57\%, isso significa que quase toda a população do município é atendida com água tratada. Em relação ao índice de consumo de energia elétrica em sistemas de esgotamento sanitário, Cajazeiras apresentou menores custos operacionais em todos os anos estudados. Já para a incidência das análises de coliformes totais fora do padrão, em nenhum dos anos estudados o município apresentou índice superior a 5\%, que é o valor máximo estabelecido pelo Ministério da Saúde.

Por sua vez, o índice de consumo de energia elétrica em sistemas de abastecimento de água, o índice de perdas de água na distribuição, o índice de coleta de esgoto e o índice de esgoto tratado, apresentaram valores preocupantes e que precisam de um olhar atencioso.

Conclui-se, portanto, que o município apresenta alguns índices positivos e que estão acima da média nacional, entretanto, há outros que demandam a necessidade de medidas corretivas e de uma boa gestão para minimizá-los e corrigi-los. 


\section{REFERÊNCIAS BIBLIOGRÁFICAS}

Água. Trata Brasil, 2020. Disponível em: < http://www.tratabrasil.org.br/saneamento/principaisestatisticas/no-brasil/agua >. Acesso em: 03 dez. de 2020.

BAZÚA-RUEDA, Er et al. Chemistry applications to wastewater treatment: case studies in Mexico and Cuba. Revista Cubana de Química, Cuba, v. 31, n. 1, p. 17-32, jan. 2019. Disponível em: http://scielo.sld.cu/pdf/ind/v31s1/2224-5421-ind-31-s1-105.pdf. Acesso em: 08 out. 2020.

BUITRAGO, Lina Claudia Giraldo; PALACIO, Carlos Alberto; MOLINA, Rubén Darío; GARCíA, Rubén Alberto Agudelo. Water quality modeling of the Medellin river in the Aburrá Valley. DYNA, Colombia, v. 82, n. 192, p. 195-202, 25 ago. 2015. Universidad Nacional de Colombia. http://dx.doi.org/10.15446/dyna.v82n192.42441.

COSTA, S. A. B. et al. Indicadores em Saneamento: Avaliação da Prestação dos Serviços de Água e de Esgoto em Minas Gerais. In: FOCA LISBOA (Ed.). Revista UFMG. Belo Horizonte: 2013. v. 20p. 334-357.

DOS SANTOS DIAS, Daniella Maria; GAMA RAIOL, Raimundo Wilson; DO NASCIMENTO NONATO, Domingos. Saneamento e direito à cidade: ponderações sobre abastecimento de água e esgotamento sanitário na cidade de Belém/PA. Direito da Cidade, v. 9, n. 4, 2017.

Esgoto. Trata Brasil, 2020. Disponível em: < http://www.tratabrasil.org.br/saneamento/principaisestatisticas/no-brasil/esgoto>. Acesso em: 03 de dez. de 2020.

Incidência de análise da água tratada de coliformes totais fora do padrão - CESAN . Portal do Observatório dos Indicadores da Cidade de Vitória. Disponível em:

https://observavix.vitoria.es.gov.br/objetivo/6/indicador/322. Acesso em: 30 de nov . 2020

HELLER, Pedro Gasparini Barbosa; VON SPERLING, Marcos; HELLER, Léo. Desempenho tecnológico dos serviços de abastecimento de água e esgotamento sanitário em quatro municípios de Minas Gerais: uma análise comparativa. Engenharia Sanitária e Ambiental, Belo Horizonte, v. 14, n. 1, p. 109-118, jan. 2009. Disponível em: https://www.scielo.br/pdf/esa/v14n1/v14n1a12.pdf. Acesso em: 15 set. 2020.

LOPES, Wilza da Silva; RODRIGUES, Andrea Carla Lima; FEITOSA, Patrícia Hermínio Cunha; COURA, Mônica de Amorim; BARBOSA, Rui de Oliveira e Dayse Luna. Determinação de um índice de desempenho do serviço de esgotamento sanitário. Estudo de caso: cidade de Campina Grande, Paraíba. Revista Brasileira de Recursos Hídricos, Porto Alegre, v. 21, n. 1, p. 1-10, 25 fev. 2016. Disponível em: https://www.scielo.br/pdf/rbrh/v21n1/2318-0331-rbrh-21-1-1.pdf. Acesso em: 05 nov. 2020.

MUNDIM, Bernardo Costa; JUNIOR, Isaac Volschan.CONGRESSO ABES FENASAN, 2017, São Paulo. Relevância dos indicadores operacionais e de qualidade do sistema nacional de informações sobre o saneamento para sistemas de abastecimento de água e esgotamento sanitário. São Paulo: ABES, 2017. 10 p. Disponível em:

http://abes.locaweb.com.br/XP/XP-EasyArtigos/Site/Uploads/Evento36/TrabalhosCompletosPDF/V017.pdf. Acesso em: 5 nov. 2020. 
NAHAS, Maria Inês Pedrosa; MOURA, Arlete Soares Alves de; CARVALHO, Rodrigo Coelho de; HELLER, Léo. Desigualdade e discriminação no acesso à água e ao esgotamento sanitário na Região Metropolitana de Belo Horizonte, Minas Gerais, Brasil. Cadernos de Saúde Pública, São Paulo, v. 35, n. 4, p. 55-67, 2019. FapUNIFESP (SciELO). http://dx.doi.org/10.1590/0102-311x00100818. Disponível em: https://www.scielosp.org/pdf/csp/2019.v35n4/e00100818/pt. Acesso em: 09 out. 2020.

NIRAZAWA, Alyni Nomoto; OLIVEIRA, Sonia Valle Walter Borges de. Sanitation indicators: analysis of variables to construct municipality indicators. Brazilian Journal Of Public Administration, Rio de Janeiro, v. 52, n. 4, p. 753-763, ago. 2018. Disponível em:

https://www.scielo.br/pdf/rap/v52n4/en_1982-3134-rap-52-04-753.pdf. Acesso em: 25 out. 2020.

PULE, Mompoloki; YAHYA, Abid; CHUMA, Joseph. Wireless sensor networks: a survey on monitoring water quality. Journal Of Applied Research And Technology, México, v. 15, n. 6, p. 562-570, dez. 2017. Universidad Nacional Autonoma de Mexico. http://dx.doi.org/10.1016/j.jart.2017.07.004. Disponível em: http://www.scielo.org.mx/pdf/jart/v15n6/2448-6736-jart-15-06-562.pdf. Acesso em: 09 set. 2020.

RASERA, Denise et al. INDICADORES PARA REGULAÇÃO DO SANEAMENTO EM ÁREAS DE POBREZA: ESTRUTURA E APLICAÇÃO EM CUBATÃO-SP, BRASIL. Ambiente e Sociedade, São Paulo, v. , n. 4, p. 6386, dez. 2017. Disponível em: https://www.scielo.br/pdf/asoc/v20n4/pt_1809-4422-asoc-20-0400061.pdf. Acesso em: 05 out. 2020.

ROSSONI, Hygor Aristides Victor et al. Aspectos socioeconômicos e de desenvolvimento humano municipal determinantes na ausência de prestadores de serviços de esgotamento sanitário no Brasil. Eng. Sanit. Ambient., Rio de Janeiro, v. 25, n. 2, p. 393-402, Mar. 2020. Disponível em: $<$ http://www.scielo.br/scielo.php?script=sci_arttext\&pid=S1413-

41522020000200393\&Ing=en\&nrm=iso>. Acesso em: 25 Nov. 2020. Epub Apr 17, 2020. https://doi.org/10.1590/s1413-41522020183887.

SOBRINHO, Renavan Andrade; BORJA, Patrícia Campos. Gestão das perdas de água e energia em sistema de abastecimento de água da Embasa: um estudo dos fatores intervenientes na rms. Engenharia Sanitária e Ambiental, Salvador, v. 21, n. 4, p. 783-795, dez. 2016. FapUNIFESP (SciELO). http://dx.doi.org/10.1590/s1413-41522016116037.

SNIS. Diagnóstico AE 2018 - SNIS - Sistema Nacional de Informações Sobre Saneamento. Disponível em: http://www.snis.gov.br/diagnostico-anual-agua-e-esgotos/diagnostico-dos-servicos-de-agua-eesgotos-2018. 2018a. Acesso em: 02 dez. 2020.

SNIS. Glossário de Informações do SNIS (AE) - SNIS - Sistema Nacional de Informações Sobre Saneamento. Disponível em: http://www.snis.gov.br/diagnostico-anual-agua-e-esgotos/diagnosticodos-servicos-de-agua-e-esgotos-2018. 2018c. Acesso em: 02 dez. 2020.

SNIS. Relação de Indicadores do SNIS (AE) - SNIS - Sistema Nacional de Informações Sobre Saneamento. Disponível em: http://www.snis.gov.br/diagnostico-anual-agua-e-esgotos/diagnostico-dos-servicosde-agua-e-esgotos-2018. 2018b. Acesso em: 02 dez. 2020. 
SNIS. Tabela Resumo de Informações e Indicadores Por Estado - SNIS - Sistema Nacional de Informações Sobre Saneamento. Disponível em: http://www.snis.gov.br/diagnostico-anual-agua-eesgotos/diagnostico-ae-2018. 2018. Acesso em: 07 nov. 2020.

SNIS. Tabela Resumo de Informações e Indicadores Por Estado - SNIS - Sistema Nacional de Informações Sobre Saneamento. Disponível em: http://www.snis.gov.br/diagnostico-anual-agua-eesgotos/diagnostico-ae-2017. 2017. Acesso em: 07 nov. 2020.

SNIS. Tabela Resumo de Informações e Indicadores Por Estado - SNIS - Sistema Nacional de Informações Sobre Saneamento. Disponível em: http://www.snis.gov.br/diagnostico-anual-agua-eesgotos/diagnostico-ae-2016. 2016. Acesso em: 07 nov. 2020.

SNIS. Tabela Resumo de Informações e Indicadores Por Estado - SNIS - Sistema Nacional de Informações Sobre Saneamento. Disponível em: http://www.snis.gov.br/diagnostico-anual-agua-eesgotos/diagnostico-ae-2015. 2015. Acesso em: 07 nov. 2020.

SNIS. Tabela Resumo de Informações e Indicadores Por Estado - SNIS - Sistema Nacional de Informações Sobre Saneamento. Disponível em: http://www.snis.gov.br/diagnostico-anual-agua-eesgotos/diagnostico-ae-2014. 2014. Acesso em: 07 nov. 2020.

SOARES, Luiz Carlos Rangel; GRIESINGER, Marilena O.; DACHS, J. Norberto W.; BITTNER, Marta A.; TAVARES, Sonia. Inequities in access to and use of drinking water services in Latin America and the Caribbean. Revista Panamericana de Salud Pública, Jun 2002, Volume 11 № 5-6 Páginas 386 - 396 Disponível em: <https://www.scielosp.org/article/rpsp/2002.v11n5-6/386-396/>. Acesso em: 01 Dec. 2020.

SOUZA, Paulo Francisco Barbosa; PETER, Maria da Glória Arrais; PINTO, Danielle Silva; NEGREIROS, Josiany Melo; CAMPOS, Felipe Mota. CONGRESSO BRASILEIRO DE CUSTOS, 19., 2012, Bento Gonçalves, Rs. Relação entre indicadores operacionais e financeiros: estudo das companhias estaduais de saneamento básico no Brasil. São Leopoldo - Rs: Associação Brasileira de Custos, 2012. 16 p. Disponível em: https://anaiscbc.emnuvens.com.br/anais/article/view/352. Acesso em: 15 nov. 2020.

SPERLING, Tiago Lages Von; SPERLING, Marcos Von. Proposição de um sistema de indicadores de desempenho para avaliação da qualidade dos serviços de esgotamento sanitário. Engenharia Sanitária e Ambiental, Belo Horizonte, v. 18, n. 4, p. 313-322, out. 2013. Disponível em: https://www.scielo.br/pdf/esa/v18n4/1413-4152-esa-18-04-00313.pdf. Acesso em: 14 out. 2020.

VIEIRA, José M. P.; BAPTISTA, Jaime Melo. Indicadores de Desempenho para Melhoria dos Serviços de Saneamento Básico. Revista Engenharia Civil - Universidade UMinho, Portugal, v. 33, n. 1, p. 87-112, jan. 2008. Disponível em: http://www.civil.uminho.pt/revista/artigos/n33/Artigo08-Pag87-112.pdf. Acesso em: 12 out. 2020.

TUDELA-MAMANI, Juan W.; LEOS-RODRÍGUEZ, Juan A.. Estimation of economic benefits due to improvements in basic sanitation services through choice experiments. Revista Chapingo Serie Ciencias Forestales y del Ambiente, México, v. 24, n. 2, p. 237-250, 30 abr. 2018. Universidad Autonoma Chapingo. http://dx.doi.org/10.5154/r.rchscfa.2017.05.037. Disponível em: http://www.scielo.org.mx/pdf/rcscfa/v24n2/2007-4018-rcscfa-24-02-237.pdf. Acesso em: 28 set. 2020. 


\section{Capítulo 3}

doi) $10.37423 / 210704413$

\section{DIAGNÓSTICO DE POTABILIDADE DA ÁGUA DE CISTERNAS EM COMUNIDADE RURAL DO SUL CEARENSE COM BASE NA AVALIAÇÃO DE PADRÃO FÍSICO-QUÍMICO}

LUAN AL VES FURTADO

NAYANNE MARIA GONCSALVES LEITE

DAMIANA ANDREIA TAVARES SOARES

ANTONIO RONDINELLY DA SILVA PINHEIRO

GEORGE DO NASCIMENTO RIBEIRO

GUILHERME RODRIGUES GOMES.

MARIA ISABEL FERREIRA DOS SANTOS
INSTITUTO FEDERAL DE EDUCACÃO. CIÊNCIA E TECNOLOGIA DA PARAÍBA

UNIVERSIDADE FEDERAL DE CAMPINA GRANDE

INSTITUTO FEDERAL DE EDUCAÇÃO, CIÊNCIA E TECNOLOGIA DA PARAÍBA

UNIVERSIDADE FEDERAL DE CAMPINA GRANDE

UNIVERSIDADE FEDERAL DE CAMPINA GRANDE

UNIVERSIDADE FEDERAL DE CAMPINA GRANDE

INSTITUTO FEDERAL DE EDUCACÃO, CIÊNCIA E TECNOLOGIA DA PARAÍBA 
Resumo: É notória a importância das cisternas como um meio de coleta e armazenamento de águas pluviais, dada à crise hídrica que assola o semiárido nordestino e a irregularidade das chuvas na região. E considerando a necessidade das águas de chuva para os mais diversos usos, entre eles o consumo humano, evidencia-se a necessidade de garantia dos aspectos de qualidade e potabilidade da água através de medidas de segurança sanitária. Diante disso, o presente artigo tem como objetivo verificar a potabilidade das águas das cisternas atendidas pelo programa federal Água para Todos em comunidades rurais, mais especificamente no Sítio Muquém, Porteiras-CE. Trata-se de um estudo quali-quantitativo, onde a etapa metodológica foi dividida em duas partes: determinação dos pontos de coleta, realizada em dez cisternas, de modo aleatório; e realização de análises físico-químicas, tanto in loco (com o uso do Estojo de testes GENCO - $\mathrm{CV}$ pH) como auxiliada pelo laboratório da Estação de Tratamento de Águas (ETA-Mutirão) da Companhia de Água e Esgoto da Paraíba (CAGEPA), em Cajazeiras. Os testes realizados foram níveis de cloro, ph, turbidez, cor e sólidos dissolvidos e os resultados obtidos foram comparados com os valores mínimos estabelecidos pela Portaria $5 / 2017$ do Ministério da Saúde. A partir das análises realizadas, foi verificado que os parâmetros de turbidez, cor e sólidos dissolvidos atendem a regulamentação brasileira, entretanto os critérios de teor de cloro e pH não são respeitados, dessa forma as dez amostras analisadas foram consideradas não potáveis.

Palavras-chave: Cisternas; Águas Pluviais; Crise Hídrica; Potabilidade; Análises Físico-Químicas. 


\section{INTRODUÇÃO}

O uso de cisternas para coleta e armazenamento de águas pluviais se apresenta como uma das melhores formas de armazenamento de água, representando também uma possibilidade para o desenvolvimento do semiárido, de modo que viabiliza a permanência de populações, mesmo em ambientes propícios a escassez hídrica.

Carvalho et al. (2017), reconhecem as cisternas como uma solução alternativa de abastecimento de água para o consumo humano. Além disso, defendem a adoção desses sistemas considerando sua viabilidade, simplicidade e adequabilidade, dentro do contexto de tecnologia apropriada, para cidades de pequeno porte e zonas rurais, cuja densidade populacional é baixa.

Segundo relatório criado através de auditoria pelo Tribunal de Contas da União (TCU), as cisternas atuam como fonte de suprimento de água em períodos de escassez, seja para a dessedentação animal, irrigação agrícola, higienização animal e humana ou mesmo para o consumo humano (BRASIL, 2006).

A Lei $11.445 / 2007$, que estabelece as diretrizes nacionais para o saneamento básico, dispõe sobre o abastecimento de água como um de seus eixos. Todavia, mesmo diante da existência de mecanismo legal que institui a universalização do acesso ao saneamento, ainda encontramos um cenário complexo, preponderantemente em pequenos núcleos populacionais. As ações inerentes ao saneamento são pouco intensas no meio rural, sendo compostas em grande parte pelo abastecimento de água, esta nem sempre se encontra em qualidade adequada ao consumo humano.

O padrão de potabilidade de águas para consumo humano é instituído através da Portaria de Consolidação № 5, de 28 de setembro de 2017, instituída pelo Ministério da Saúde. Verifica-se, diante desta, um aporte legal que reconhece a importância do monitoramento qualitativo, norteando e viabilizando a implementação de medidas para garantia da potabilidade da água, incluindo as de cisterna, para diferentes fins.

A Portaria № 5/2017, ainda define água potável como aquela com qualidade adequada ao consumo humano, atendendo à características de qualidade física, organoléptica e química. Deste modo, fica estabelecido que, o sabor e odor da água devem ser não objetáveis, não devendo conter microorganismos patogênicos como Escherichia coli ou coliformes termotolerantes em $100 \mathrm{ml}$. Deve possuir também níveis reduzidos de cor aparente e turbidez, além de não conter qualquer tipo de substâncias químicas em concentração maior que a tolerável à garantia da saúde humana. 
Embora as águas de chuva tenham características adequadas para sua utilização em múltiplos fins, existem contribuições oriundas da zona de captação que influem diretamente na sua potabilidade, podendo haver contaminação, por conseguinte tornando o seu uso inapropriado. Para fins potáveis, a água de chuva deve passar por tratamento e maiores cuidados, como o descarte das primeiras águas, o uso de filtros e a desinfecção.

Em seu trabalho envolvendo mecanismos de descarte de primeiras águas, Andrade Neto (2013) afirma que em locais cuja densidade populacional é elevada e é verificada a presença de indústrias, os índices de poluição atmosférica são consideráveis. Vale salientar ainda, que a utilização de insumos orgânicos e químicos para produção agrícola, bem como a contaminação microbiológica, podem ser considerados agentes responsáveis pela diminuição da pureza e qualidade do ar atmosférico. Todavia, é válido afirmar que a contaminação se dá em grande maioria em núcleos urbanos, cuja intensidade de poluentes na atmosfera é relevante.

Andrade Neto (2013) ainda afirma que, no semiárido nordestino, especialmente nos pequenos núcleos urbanos e em comunidades rurais, em detrimento dos baixos índices de contaminação atmosférica, os níveis de concentração de poluentes possuem valores tão reduzidos que não chegam a comprometer a qualidade das águas de chuva.

Alguns autores dão ênfase a minimização de riscos à saúde através da qualidade e potabilidade da água. Este aspecto trata-se de uma consequência do desenho adequado dos sistemas de captação e da capacitação de seus beneficiários quanto a utilização, manutenção e limpeza.

As cisternas usualmente utilizadas no semiárido são fruto de programas do Governo Federal, que são tratados atualmente pela Secretaria Especial do Desenvolvimento Social. Podem ser descritas como tanques, que podem tanto ser construídos com placas de fibrocimento, como concedidos na forma de reservatórios em polietileno. Possuem a finalidade de armazenamento imediato de águas de chuva, captadas através do telhado da residência e próximo ao local de instalação dele.

Considerando a necessidade das águas de chuva, dada a limitação de recursos hídricos disponíveis no semiárido, o seu uso para necessidades básicas ligadas à garantia e manutenção da vida, bem como os riscos inerentes ao consumo de águas contaminadas, é imprescindível o tratamento de água para o consumo humano, cuja finalidade inicial é garantir sua potabilidade.

O presente estudo, constitui-se da análise de parâmetros químicos e físicos de amostras de água coletadas em cisternas em comunidade rural do Sul Cearense. Tais análises buscam apresentar um 
diagnóstico parcial do ponto de vista da potabilidade da água para o consumo humano, fundamentado nos parâmetros estabelecidos pela legislação vigente, bem como na bibliografia nacional.

\section{MATERIAIS E MÉTODOS}

O estudo desenvolveu-se no Sítio Muquém, situado à cidade de Porteiras, na região sul do estado do Ceará. Segundo os dados do Instituto de Pesquisa e Estratégia Econômica do Ceará (IPECE, 2016) o município de Porteiras possui uma área territorial de $217,6 \mathrm{~km}^{2}$ e uma população de 15.061 habitantes, sendo que deste total, 8.872 residem na zona rural. O clima característico da região é o semiárido.

A pesquisa caracteriza-se como uma abordagem de caráter descritivo e exploratório, consistindo na verificação da potabilidade das águas de cisterna de um grupo de famílias atendidas pelo ‘Projeto Água para Todos', idealizado pelo Governo Federal.

\subsection{COLETA DE AMOSTRAS}

Para desenvolvimento do estudo, buscou-se georreferenciar os pontos de amostragem dentro da comunidade conforme exibe a Fig 1, sendo classificadas como 'amostra', seguida da ordem de coleta expressa em número. Ao todo, definiram-se dez unidades para estudo, selecionadas através de amostragem aleatória, considerando a representatividade destas em relação ao conjunto.

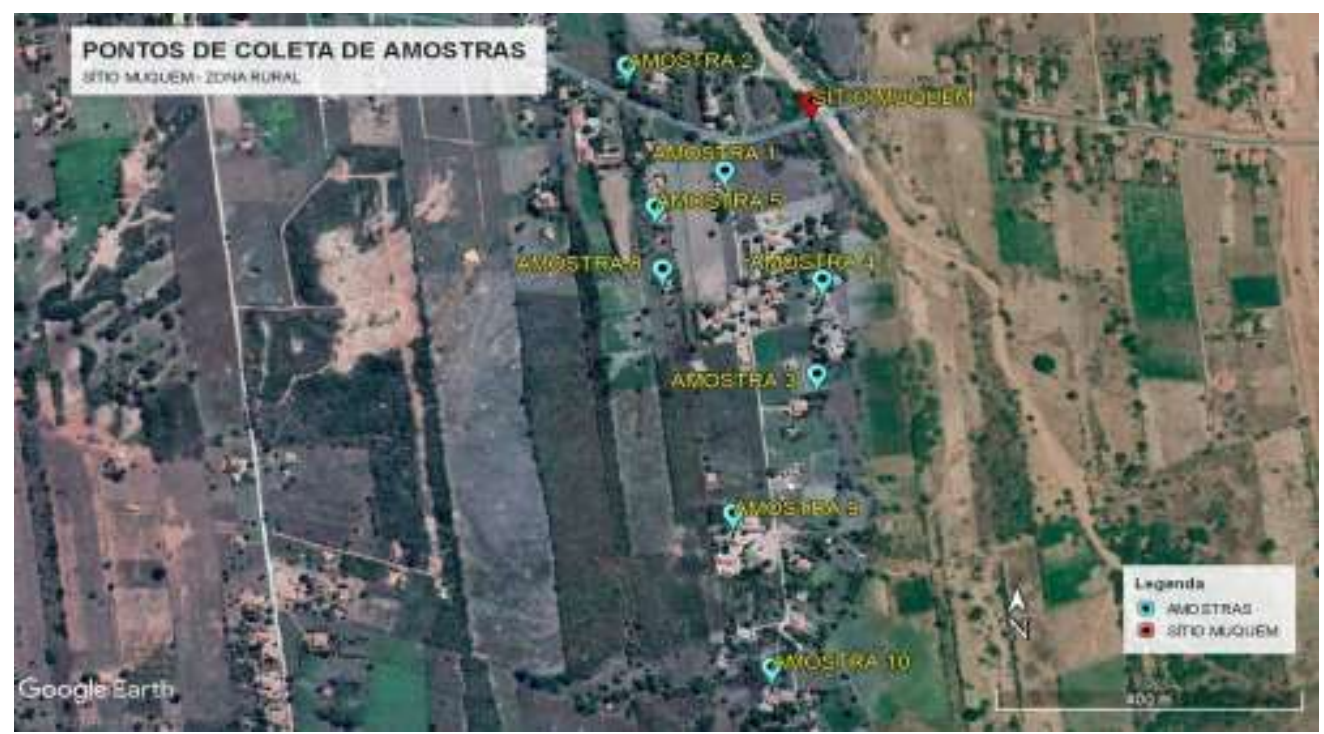

Figura 1- Pontos de Coleta. Fonte: Adaptado de Google Earth (2019).

As coletas foram realizadas através de amostragem única e feitas diretamente nos reservatórios com o auxílio de amostrador. Após cada coleta, as amostras que seguiriam para análise laboratorial eram 
identificadas e acondicionadas em uma caixa térmica. Os procedimentos analíticos realizados durante a coleta, baseados em um plano de trabalho não superior a 12 horas, encontram-se descritos em Manual de procedimentos de amostragem e análise físico-química da água e o Manual prático de análise de água.

\subsection{ANÁLISE DE AMOSTRAS}

As análises físico-químicas foram realizadas com o fracionamento da água coletada em duas alíquotas, que correspondem a metodologia de verificação dos parâmetros, divididas em duas etapas que são: análise in situ, para averiguar o nível de cloro para cada reservatório, e análise laboratorial, que corresponde a verificação de pH, turbidez, cor e Sólidos Totais Dissolvidos (TDS).

Os níveis de cloro foram verificados com o uso do Estojo de testes $\mathrm{GENCO}-\mathrm{Cl} / \mathrm{pH}$, seguindo as determinações estipuladas pelo fabricante. Tal verificação foi desenvolvida em campo durante o ato de coleta, considerando-se a volatilidade do cloro quando exposto ao $\mathrm{O} 2$.

As demais análises físico-químicas, foram realizadas em parceria com o laboratório da Estação de Tratamento de Águas (ETA - Mutirão), da Companhia de Água e Esgotos da Paraíba (CAGEPA), em Cajazeiras.

A análise dos resultados obtidos para cada amostra foi feita com base nos valores mínimos estabelecidos na Portaria de Consolidação № 5, de 28 de setembro de 2017, do Ministério da Saúde. No documento são estabelecidos os padrões de potabilidade, definidos como o conjunto de valores permitidos como parâmetros de qualidade da água para consumo humano (BRASIL, 2011, p. 3).

\section{RESULTADOS E DISCUSSÃO}

Conforme observou-se nas coletas de campo, os mecanismos de captação de águas pluviais na comunidade não possuem aparatos para o descarte de águas de chuva iniciais, filtros de autolimpeza, ou redutores de turbulência, que promovem a segurança sanitária e maior qualidade do volume que segue para armazenamento. A captação inicial é efetuada por telhados residenciais, em seguida o volume é direcionado para as calhas, seguindo por condutos em PVC diretamente para as cisternas em polietileno, cuja capacidade máxima de armazenagem é de 16 mil litros.

O monitoramento do $\mathrm{pH}$ é um importante indicador sobre a qualidade da água, e para que haja controle de sua acidez, pois a presença de acidez excessiva na água influencia no seu processo de tratamento e pode ocasionar corrosão nas instalações hidráulicas. 
De acordo com a Resolução № 5/2017, o potencial Hidrogeniônico da água deve ser mantido no intervalo entre 6 e 9,5, sendo importante que esteja alcalina para promover a eliminação de toxinas do organismo humano. Os valores de $\mathrm{pH}$ obtidos nas amostras, figura 2, apresentaram uma média de 4,615 土 0,695, estando este intervalo fora dos valores normativos de referência. Segundo Jaques (2005), para o pH da água de chuva em regiões pouco alteradas, como localidades rurais, é considerado normal valores que indicam acidez, próximos à 5,00, devido à presença de gases como CO2 e SO4 e as reações químicas com a água.

Segundo Cabral e Araújo (2016), "a Turbidez (UT) é a medição da resistência da água à passagem de luz, é provocada pela presença de partículas flutuando na água e um parâmetro de aspecto estético de aceitação ou rejeição do produto" (p. 14). O resultado obtido durante a análise, conforme apresenta a figura 2, apresentou uma média de 0,455 土 0,355, sendo que para a Resolução № 5/2017, o valor máximo permitido é 5 UT (unidade de Turbidez). Deste modo, o parâmetro analisado está em acordo com a regulamentação.

É válido ressaltar que, embora os níveis de turbidez se mostrem abaixo do que recomendado para o valor limite, na etapa de coleta das amostras identificou-se, através de inspeção visual, a presença de material orgânico em todas as cisternas examinadas, como folhas, frutos e galhos, decorrentes do grande volume arbóreo nos locais próximos às superfícies de captação.

A cor, este é um parâmetro que indica a presença de substâncias dissolvidas na água, sendo, assim como a turbidez, um parâmetro que reflete o aspecto estético do líquido, impactando na aceitação ou rejeição do produto (CABRAL; ARAÚJO, 2016). Pela normativa, o valor máximo considerado pela resolução é de 15 uH (unidade Hazen). Como nas amostras esse padrão varia entre 0,6 e 8,2 uH, figura 2, podemos afirmar que está dentro dos limites preconizados pela regulamentação.

O alto valor obtido nas amostras 1 e 8, sendo estes 6,3 e 8,2 uH, respectivamente, se devem à alta presença de matéria orgânica dentro das cisternas, como anteriormente citado. Segundo Andrade Neto, "a contaminação da água de chuva geralmente ocorre na superfície de captação (telhado, solo ou outra superfície preparada ou natural) ou quando está armazenada de forma não protegida" (2003, p. 3). Para a prevenção desta contaminação, devem ser adotadas barreiras sanitárias para o descarte das primeiras águas, pois estas carreiam os resíduos da zona de captação, tendo em vista prevenir a contaminação da cisterna. 
Segundo Cabral e Araújo (2016) "sólidos totais dissolvidos é o conjunto de todas as substâncias orgânicas e inorgânicas contidas num líquido sob formas moleculares ionizadas ou microgranulares" (201x, p. 5). Pela resolução, o valor máximo na água é de 1000 mg/L, sendo o resultado obtido pela análise laboratorial de média 13,815 土 9,885, conforme mostra a figura 2, o que atende de maneira clara a normatização brasileira.

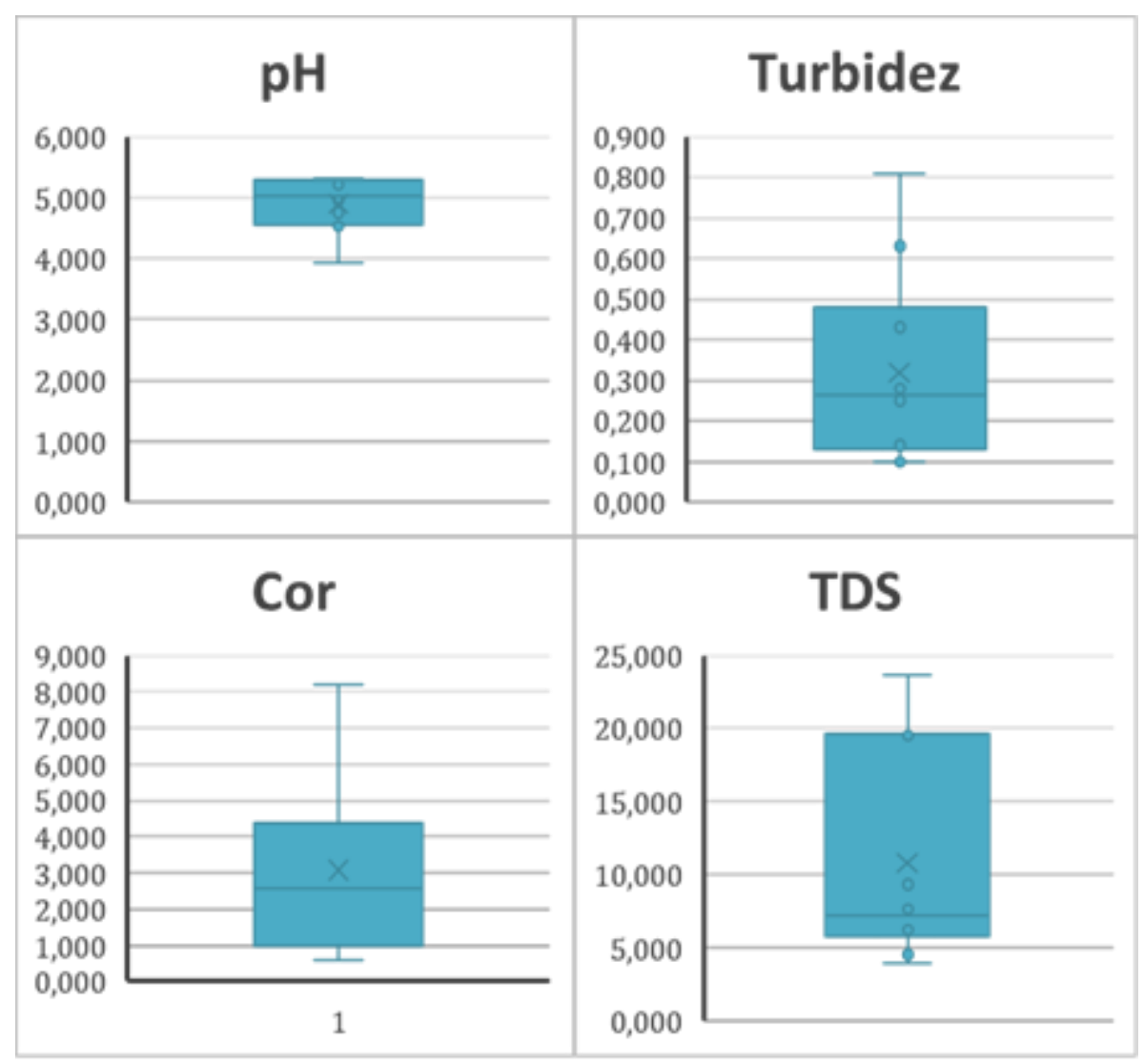

Figura 2 - Resultados laboratoriais para pH, turbidez, cor e TDS.

Fonte: Elaboraçăo própria (2020).

O teor de cloro, segundo a Resolução № 5/2017 estabelece, é essencial no procedimento de tratamento de água, visto que, toda ela deve ser disponibilizada para o consumo humano desde que passe por processo de desinfecção ou cloração, assegurando um teor mínimo de cloro residual livre de $0,2 \mathrm{mg} / \mathrm{L}$ em qualquer ponto do sistema de distribuição de água, incluindo reservatórios, e máximo de $2,0 \mathrm{mg} / \mathrm{L}$ (BRASIL, 2017, p.44).

O teor de cloro ativo que permanece após a desinfecção, por cloração, da água, permite que a qualidade microbiológica seja mantida em condições de consumo. Assim, o processo de cloração é essencial para manter a segurança contra organismos patogênicos presentes na água, onde o teor de cloro residual serve para garantir a segurança em caso de eventual contaminação do reservatório. 
Conforme o quadro 1 reúne, através da análise de campo realizada para averiguação dos níveis de cloro, nenhuma das cisternas apresentou o valor mínimo exigido pela legislação.

Quadro 1 - Quadro síntese de médias para os parâmetros avaliados

\begin{tabular}{|c|c|c|c|c|c|}
\hline Parâmetros & $\mathbf{p H}$ & $\begin{array}{c}\text { Turbidez } \\
(\mathbf{u T})\end{array}$ & $\begin{array}{c}\text { Cor } \\
(\mathbf{u H})\end{array}$ & $\begin{array}{c}\text { TDS } \\
(\mathbf{m g} / \mathbf{L})\end{array}$ & $\begin{array}{c}\text { Cloro } \\
(\mathbf{m g} / \mathbf{L})\end{array}$ \\
\hline Resolução N ${ }^{\circ} 5$ & $6-9,5$ & $<5$ & $<15$ & $<1000$ & $>0,2$ \\
\hline Amostras & $3,92-5,31$ & $0,1-0,81$ & $0,6-8,2$ & $\begin{array}{c}3,93- \\
23,7\end{array}$ & 0,0 \\
\hline
\end{tabular}

Fonte: Elaboração própria (2020).

Deste modo, é possível inferir o atendimento à regulamentação brasileira dos parâmetros de Turbidez, Cor e Sólidos Totais Dissolvidos. No entanto, como os critérios de potencial Hidrogeniônico e teor de cloro não são respeitados, a água presente nas cisternas analisadas pode ser considerada não potável, sendo o número de amostras coletadas considerado representativo para a quantidade total de cisternas na região onde foi desenvolvido o estudo.

\section{CONCLUSÕES}

Através das amostras recolhidas em campo, sua análise laboratorial e posterior verificação dos dados coletados, em estudo comparativo para com o estabelecido pela legislação vigente, conforme apresentado, é possível classificar a água encontrada nos reservatórios como não potável. Deste modo, constitui-se como não adequada ao consumo humano, deixando de atender um dos princípios fundamentais do programa ao qual pertence, que é a dessedentação humana.

Embora seu uso para fins potáveis seja restrito, há possibilidade de utilização da água para outras aplicações, como o uso para irrigação, dessedentação animal e outros usos que não incluem o consumo humano sem prévio tratamento.

Dado o sistema convencional através do qual os reservatórios são abastecidos, recomenda-se a adoção de mecanismos de descarte de escoamento inicial, com vista a diminuição de matéria orgânica e impurezas observadas durante as coletas. De acordo com Andrade Neto (2013), apenas o primeiro milímetro da precipitação, em regiões pouco industrializadas, é suficiente para "limpar" a atmosfera e a superfície de captação, estando a qualidade do restante da chuva preservada. Visando condicionar os sistemas ao máximo aproveitamento, é essencial o dimensionamento de um sistema que garanta 
o descarte deste volume correspondente à $1 \mathrm{~mm}$ sobre a superfície de captação. A adoção de dispositivos apropriados a realidade local pressupõe estudos futuros sobre o assunto.

A regularização dos níveis $\mathrm{pH}$ para com os limites preconizados por lei supõe metodologias de aplicação do hidróxido de cálcio, comumente utilizadas em Estações de Tratamento de Água-ETA (FUNASA, 2014). No entanto, é sugerida pesquisa aplicada, para adequação do tratamento ao sistema de captação de água em cisternas, vista as diferenças entre os dois sistemas e irregularidade dos volumes captados, dependentes da sazonalidade das chuvas no semiárido.

Para efetuar a desinfecção da água, a partir da cloração, pode ser aplicado o hipoclorito de sódio, que é uma forma menos onerosa do produto. Porém, é importante destacar que a quantidade a ser aplicada no reservatório depende diretamente do volume presente na cisterna, de modo que seja atendido aos limites do teor de cloro residual livre estabelecidos pela legislação brasileira.

Por fim, para a realização do adequado tratamento, devem ser realizadas ações de educação sanitária para os membros da comunidade, através de agentes comunitários, palestras e treinamentos, para a adoção de boas práticas como a inspeção, manutenção e limpeza dos dispositivos de coleta e armazenamento de águas pluviais.

\section{AGRADECIMENTOS}

O presente trabalho foi realizado com apoio da Coordenação de Aperfeiçoamento de Pessoal Nível Superior - Brasil (CAPES) - Código de Financiamento 001, agradeço também ao Programa de Mestrado Profissional em Rede Nacional em Gestão e Regulação de Recursos Hídricos - ProfÁgua, Projeto CAPES/ANA AUXPE № 2717/2015, pelo apoio técnico científico aportado até o momento. 


\section{REFERÊNCIAS}

ANDRADE NETO, C. O. Segurança sanitária das águas em cisternas rurais. 4o Simpósio Brasileiro de Captação e Manejo de Água de Chuva. Juazeiro, 2003. Anais do 4o Simpósio Brasileiro de Captação e Manejo de Água de Chuva. Juazeiro: ABCMAC,;2003-B. Disponível em: <http://www.abcmac.org.br/files/simposio/4simp_cicero_segurancasanitariasdaaguadecisterna.pdf >. Acesso em: 01 fev. 2020.

BRASIL, G. P. Tribunal de Contas da União. Ação construção de cisternas para armazenamento de água: Relatório de avaliação do programa. Brasília: Biblioteca Ministro Ruben Rosa, 2006. 131 p.

BRASIL. Ministério da Saúde. Gabinete do Ministro. Portaria de consolidação no 5, de 28 de setembro de 2017. Consolidação das normas sobre as ações e os serviços de saúde do Sistema Único de Saúde. Diário Oficial da União, Brasília, DF, 28 set. 2017. p. 926.

BRASIL. Ministério da Saúde. Portaria no 2914, de 12 de dezembro de 2011. Dispõe sobre os procedimentos de controle e de vigilância da qualidade da água para consumo humano e seu padrão de potabilidade. Diário Oficial da União, Brasília, DF, 12 dez. 2011. p. 38.

COSTA, A. R. F. da. Limites de aplicabilidade para sistemas automáticos de descarte de água de chuva: Estudo de caso. Orientador: Profo. Dr. Ramon Lucas Dalsasso. 2011. 69 p. TCC (Bacharelado em Engenharia Sanitária e Ambiental) - UNIVERSIDADE FEDERAL DE SANTA CATARINA, Florianópolis, 2001. DOI 625. Disponível em: <https://repositorio.ufsc.br/handle/123456789/124546>. Acesso em: 30 jan. 2020.

IPECE (Instituto de Pesquisa e Estratégia Econômica do Ceará) Perfil Municipal. 2007. Disponível em: <http://www2.ipece.ce.gov.br/atlas/capitulo1/12/129.htm > Acesso em: 30 jan. 2020.

Manual de Saneamento- FUNASA (Fundação Nacional de Saúde). Disponível em: <http://www.funasa.gov.br/biblioteca-eletronica/publicacoes/engenharia-de-saude-publica//asset_publisher/ZM23z1 KP6s6q/content/manual-de-saneamento?inheritRedirect=false> Acesso em: 30 jan. 2020.

MURPHY, S. General Information on Solids. [2007]. Disponível em: <http://bcn.boulder.co.us/basin/data/BACT/info/TDS.html>. Acesso em: 01 fev. 2020

PORTAL TRATAMENTO DE ÁGUA. Qualidade da água. [2015]. Disponível em: <https://www.tratamentodeagua.com.br/artigo/qualidade-da-agua/>. Acesso em: 31 jan. 2020.

Análises do processo de desinfecção das águas para consumo humano . [2017]. Disponível em: <https://www.tratamentodeagua.com.br/artigo/analises-do-processo-dedesinfeccao-das-aguas-para-o-consumo-humano/>. Acesso em: 01 fev. 2020.

CARVALHO, A. P. M.; SILVA, J. N.; SANTOS, V. S.; FERRAZ, R. R. Avaliação dos parâmetros de qualidade da água de abastecimento alternativo no distrito de Jamacaru em Missão Velha-CE. Iniciação - Revista de Iniciação Científica, Tecnológica e Artística, São Paulo, v.7, n.1, p. 35-51, nov. 2017. ISSN: 2179474X. Disponível em: http://www1.sp.senac.br/hotsites/blogs/revistainiciacao/wpcontent/uploads/2017/11/4-226_IC_ArtigoRevisado.pdf. Acesso em: 25 jun. 2021. (Carvalho et al.) 
JACQUES, R. C. Qualidade da água de chuva no município de Florianópolis e sua potencialidade para aproveitamento em edificações. 2005. 102 f. Dissertação (Mestrado em Engenharia Ambiental) Universidade Federal de Santa Catarina, Florianópolis, 2005. Disponível em: https://repositorio.ufsc.br/bitstream/handle/123456789/102214/221552.pdf?sequence=1\&isAllowe $\mathrm{d}=\mathrm{y} \% 20 \% 20$ p.58. Acesso em: 25 jun. 2021. (Jacques)

CABRAL, L. N.; ARAÚJO, S. M. S. Qualidade da água em áreas rurais: análise bacteriológica e físicoquímica das águas dos tanques de pedra das comunidades KM 21 (Campina Grande) e Pedra Redonda (Pocinhos). Revista Brasileira de Geografia Física, Pernambuco, v.9, n.6, p. 1737-1753, jan. 2016. ISSN: 1984-2295.

(Cabral e Araújo)

NETO, C. O. A. Aproveitamento imediato de água de chuva. Revista Eletrônica de Gestão e Tecnologias Ambientais - GESTA, São Paulo, v.1, n.1, p. 073-086, jan. 2013 ISSN: 2317-563X. 


\section{Capítulo 4}

doi) $10.37423 / 210704414$

SELEÇÃO DE ÁREAS PARA IMPLANTAÇÃO DE ATERRO SANITÁRIO NO MUNICÍPIO DE SÃO JOÃO DO RIO DO PEIXE-PB, UTILIZANDO TÉCNICAS DE GEOPROCESSAMENTO

Wamon Salomão Dantas Torres

\section{Cinthya Santos da Silva}

Antonio Rondinelly da Silva Pinheiro

Nayanne Maria Gonçalves Leite

Maria Isabel Ferreira dos Santos
Instituto Federal de Educação, Ciência e

Tecnologia da Paraíba - Campus Cajazeiras

Instituto Federal de Educação, Ciência e

Tecnologia da Paraíba - Campus Cajazeiras

Universidade Federal de Campina Grande Campus Sumé

Universidade/Federal de Campina Grande Campus Sumé

Instituto Federal de Educaçăo, Ciência e fecnologia da Paraíba - Campus Cajazeiras 
Resumo: A produção de resíduos sólidos no Brasil, a cada ano, apresenta um crescimento significativo e condizente com o seu aumento populacional, entretanto, a maioria das cidades brasileiras, principalmente na região Nordeste, não possuem destinação ambientalmente adequada para esses resíduos, como é o caso do município de São João do Rio do Peixe na Paraíba, o que infringe a Lei $n^{\circ} 12.305 / 2010$. Dessa forma, neste trabalho foi calculada a área necessária a inserção de um aterro sanitário de pequeno porte, para a cidade em estudo, e através de ferramentas de geoprocessamento, utilizadas para a geração de mapas temáticos, foi possível indicar áreas propicias a implantação do aterro, atendendo assim, parcialmente, os critérios exigidos na Norma Técnica Brasileira a respeito dos aterros sanitários de pequeno porte; no que se refere a adoção de Unidades de Gerenciamento Integrada de Resíduos Sólidos Urbanos para municípios abaixo de 20.000 habitantes; e na Resolução do Conselho Nacional do Meio Ambiente, que estabelece os critérios e diretrizes para o licenciamento ambiental de aterro sanitário de pequeno porte de resíduos sólidos urbanos.

Palavras-Chave: Resíduos Sólidos. Lei $n^{\circ}$ 12.305. Aterro Sanitário. Geoprocessamento. Legislação Ambiental. 


\section{INTRODUÇÃO}

No Brasil, na maioria de suas cidades, não existe um destino adequado para o descarte de resíduos sólidos urbanos, o que leva a deposição em lixões a céu aberto e aterros controlados, acarretando uma série de complicações para o meio ambiente e à saúde pública. Segundo o Panorama da Associação Brasileira de Empresas de Limpeza Pública e Resíduos Especiais (ABRELPE) de 2018/2019, os resíduos sólidos gerados no Brasil chegaram a 79 milhões de toneladas em 2018, destes, 29,5 milhões de toneladas foram descartados em locais inadequados em 3.001 dos 5.571 municípios.

Ainda de acordo com a ABRELPE (2019), a Região Nordeste foi a que teve o menor índice de cobertura de coleta de resíduos sólidos urbanos no país. Os 1.794 municípios da região geraram 53.975 toneladas em 2018, das quais $81,1 \%$ foram coletadas; porém, ao menos 6 em cada 10 toneladas coletadas receberam o destino inadequado, tais como lixões e aterros controlados. De acordo com a Superintendência de Administração do Meio Ambiente da Paraíba (COPAM, 2019), cerca de 71,5\% dos municípios do estado possuem áreas degradadas e potencialmente contaminadas por disposição irregular de resíduos sólidos.

O município de São João do Rio do Peixe encontra-se neste percentual; de acordo com a Secretaria de Infraestrutura do município, a quantidade de resíduos coletados na cidade pelo orgão é de 14 toneladas/dia, sendo estes, dispostos em um lixão a céu aberto, desta forma, infrigindo a legislação ambiental vigente, a Lei n 12.305 (BRASIL, 2010), que Institui a Política Nacional de Resíduos Sólidos, e determina disposição final dos resíduos em aterros sanitários, como a ambientalmente adequada.

Diante desta situação, no ano de 2019, a administração pública municipal aderiu ao Projeto "Fim dos Lixões", que vem sendo implementado pelo Ministério Público da Paraíba (MPPB, 2020), e assinou o acordo de não-persecução penal e o Termo de Ajustamento de Conduta (TAC), propostos pela instituição, comprometendo-se a encontrar a solução técnica mais viável para o destino adequado dos resíduos sólidos e a acabar com o lixão da cidade até $1^{\circ}$ de dezembro de 2020.

Entretanto, com a sanção da Lei $n^{\circ} 14.026$ (BRASIL, 2020), que atualiza o marco legal do saneamento básico, a Lei $\mathrm{n}^{\circ} 12.305$ foi alterada quanto aos prazos para a disposição final ambientalmente adequada dos rejeitos, onde, os municípios com população inferior a 50.000 mil habitantes no Censo 2010, têm o novo prazo definido para as adequações a Lei até 2 de agosto de 2024; contudo, estes devem até 31 de dezembro de 2020 ter elaborado um plano intermunicipal de resíduos sólidos ou 
plano municipal de gestão integrada de resíduos sólidos, que disponham de mecanismos de cobrança que garantam sua sustentabilidade econômico-financeira.

Contudo, não há informação oficial sobre a existência ou processo de elaboração de um plano intermunicipal de resíduos sólidos ou plano municipal de gestão integrada de resíduos sólidos, para a cidade de São João do Rio do Peixe, desta forma, prevalece a data limite de $1^{\circ}$ de dezembro de 2020 para o encerramento das atividades no lixão, conforme acordado com o MPPB.

A utilização de geoprocessamento visa facilitar e acelerar o procedimento na seleção de possíveis áreas para implantação de aterro sanitário, evitando desperdício de recursos humanos e financeiros, uma vez que o processo convencional é complexo e envolve diversos aspectos técnicos, econômicofinanceiros, sociais, políticos e legais, cujo levantamento de informações geralmente é oneroso e de difícil integração e manipulação (POAGUE et al., 2018); em contrapartida a esse processo, as ferramentas de geoprocessamento se mostram potencialmente eficazes e de baixo custo (CARRILHO; CANDIDO; SOUZA, 2018).

Desse modo, este trabalho possui por finalidade encontrar possíveis áreas que possam ser utilizadas à implantação de um aterro sanitário para o descarte correto de resíduos sólidos urbanos, levando em consideração a legislação e as normas técnicas vigentes, se utilizando de ferramentas de geoprocessamento.

\section{REFERENCIAL TEÓRICO}

Este capítulo discorre sobre a Norma Técnica Brasileira a respeito dos aterros sanitários de pequeno porte; a Deliberação do Conselho de Proteção Ambiental do Estado da Paraíba, sobre orientações técnicas requeridas no âmbito do licenciamento ambiental junto à Superintendência de Administração do Meio Ambiente no que se refere a adoção de Unidades de Gerenciamento Integrada de Resíduos Sólidos Urbanos para municípios abaixo de 20.000 habitantes, e sobre a Resolução do Conselho Nacional do Meio Ambiente, que estabelece os critérios e diretrizes para o licenciamento ambiental de aterro sanitário de pequeno porte de resíduos sólidos urbanos.

\subsection{ABNT NBR 15.849:2010}

A maior parte dos municípios brasileiros tem pequena população e apresenta contextos ambientais bem diversificados. Nestes municípios ou associações de municípios, sempre que as condições físicas permitem, é possível a implantação de sistemas de disposição de resíduos simplificados, em razão das 
pequenas quantidades e das características dos resíduos gerados diariamente, sem prejuízo do controle de impactos ambientais e sanitários.

A Associação Brasileira de Normas Técnicas (ABNT), na sua NBR 15.849/2010, trata a respeito dos Resíduos sólidos urbanos - Aterros sanitários de pequeno porte - Diretrizes para localização, projeto, implantação, operação e encerramento. No seu tópico 3, a norma discorre sobre os termos e definições, e no seu subtópico 3.2, traz a definição de aterro sanitário de pequeno porte, que é:

Aterro sanitário para disposição no solo de resíduos sólidos urbanos, até 20 toneladas por dia ou menos, quando definido por legislação local, em que, considerados os condicionantes físicos locais, a concepção do sistema possa ser simplificada, adequando os sistemas de proteção ambiental sem prejuízo da minimização dos impactos ao meio ambiente e a saúde pública. (ABNT NBR 15.849, 2010, pág. 2)

No subtópico 4.1 a norma expõe os critérios para a seleção da área a ser utilizada como aterro sanitário de pequeno porte, onde devem ser observados no mínimo os seguintes fatores de análise para a avaliação da área, conforme a Tabela 1:

Tabela 1 - Critérios para a seleção da área a ser utilizada como aterro sanitário de pequeno porte

\begin{tabular}{|c|c|}
\hline a) & $\begin{array}{l}\text { para tipo consistência e granulometria das camadas de subsolo na base do aterro; } \\
\text { recomenda-se a utilização de solos naturalmente pouco permeáveis (solos argilosos, } \\
\text { argilo-arenosos, ou argilo-siltosos) }\end{array}$ \\
\hline b) & $\begin{array}{l}\text { no caso de existência de corpos d'água superficiais na área ou em eu entorno imediato; } \\
\text { recomenda-se o respeito a uma distância mínima de } 200 \text { m de qualquer coleção hídrica } \\
\text { ou curso d'água }\end{array}$ \\
\hline c) & proximidade do freático $\mathrm{e}$ \\
\hline d) & rristicas nao devem ser ut1 \\
\hline e) & $\begin{array}{l}\text { as características topográficas da área devem ser tais que permitam uma das soluções } \\
\text { adotáveis para o preenchimento do aterro, recomenda-se locais com declividades } \\
\text { superior a } 1 \% \text { e inferior a } 30 \%\end{array}$ \\
\hline f) & $\begin{array}{l}\text { recomenda-se distância do limite da área útil do aterro a núcleos populacionais vizinhos } \\
\text { mínima de } 500 \mathrm{~m}\end{array}$ \\
\hline g) & $\begin{array}{l}\text { a vida útil previsível do aterro de pequeno porte passível de ser implantado na área deve } \\
\text { ser superior a } 15 \text { anos }\end{array}$ \\
\hline
\end{tabular}

Fonte: ABNT, NBR 15.849/2010. 


\subsection{DELIBERAÇÃO N 4050/2019 - COPAM}

A Deliberação n 4.050, de 07 de Outubro de 2019, do Conselho de Proteção Ambiental do Estado da Paraíba (COPAM), dispõe sobre orientações técnicas para os procedimentos da Superintendência de Administração do Meio Ambiente (SUDEMA), a serem adotados, considerando a necessidade de atualização da NA-101 no que se refere a adoção de Unidades de Gerenciamento Integrada de Resíduos Sólidos Urbanos (UGIRSU) para municípios abaixo de 20.000 habitantes a serem requeridas no âmbito do licenciamento ambiental junto à SUDEMA.

De acordo a Deliberação, no seu Art. $3^{\circ}$, definição XI, a UGIRSU é:

Local onde é realizada a separação da matéria orgânica putrescível (restos de alimentos, aparas e podas de jardins etc.), materiais recicláveis, rejeitos e resíduos especiais presentes no lixo. A parte orgânica é destinada ao pátio de compostagem, onde é submetida a um processo de conversão biológica em composto orgânico, os materiais recicláveis são encaminhados para inserção na cadeia produtiva e o rejeito é encaminhado para disposição final ambientalmente adequada. (Deliberação nº 4.050 - COPAM, 2019, pág. 3)

Dessa forma, pela complexidade das ações que serão realizadas na UGIRSU, faz-se necessária que a mesma esteja inserida na área destinada as operações do aterro sanitários.

O Art. $6^{\circ}$ da Deliberação trata a respeito dos requisitos mínimos exigidos para a escolha da localização da área, implantação e operação da UGIRSU, de acordo com a Tabela 2:

Tabela 2 - Requisitos mínimos exigidos para a escolha da localização da área, implantação e operação da UGIRSU

\begin{tabular}{l|l}
\hline a) & $\begin{array}{l}\text { A localização da área não poderá ocorrer, em nenhuma hipótese, em áreas erodidas, em } \\
\text { especial em voçorocas, em áreas cársticas, em depósitos aluvionares ou em Áreas de } \\
\text { Preservação Permanente (APP) }\end{array}$ \\
\hline b) & $\begin{array}{l}\text { A localização da área não poderá ocorrer em área com solo de baixa permeabilidade e } \\
\text { com declividade média superior a } 30 \%\end{array}$ \\
\hline c) & $\begin{array}{l}\text { A localização da área não poderá estar sujeita a eventos de inundação, situada a uma } \\
\text { distância mínima de 200,0 metros de cursos d'água (intermitentes e perenes), nascentes } \\
\text { e olhos d'água perenes, barramento ou represamento artificial de cursos d'água naturais }\end{array}$ \\
\hline d) & $\begin{array}{l}\text { A localização da área deve obedecer a uma distância mínima de 500,0 metros de } \\
\text { residências isoladas ou aglomerações habitacionais (residências de aglomerados } \\
\text { habitacionais em agrovila ou vila) }\end{array}$ \\
\hline
\end{tabular}


e)

A localização da área deve estar a uma distância mínima de 100,0 metros de rodovias e estradas, a partir da faixa de domínio estabelecida pelos órgãos competentes

f) A localização da área deve estar a uma distância mínima de $10 \mathrm{Km}$ de aeródromos cadastrados na Agência Nacional de Aviação Civil (ANAC)

g)

A localização da área deve estar a uma mínima de 15,0 metros da faixa de servidão de redes de alta tensão (NBR 5.422/1985)

Fonte: Deliberação $n^{\circ}$ 4.050/2019 - COPAM.

\subsection{RESOLUÇÃO N 404/2008 - CONAMA}

A Resolução $n^{\circ}$ 404, de 11 de novembro de 2008, do Conselho Nacional do Meio Ambiente (CONAMA), estabelece os critérios e diretrizes para o licenciamento ambiental de aterro sanitário de pequeno porte de resíduos sólidos urbanos. No seu $\operatorname{Art.} 1^{\circ}, \S 1^{0}$ considera que aterros sanitários de pequeno porte são aqueles com disposição diária de até 20 t (vinte toneladas) de resíduos sólidos urbanos.

O Art. $4^{\circ}$ da Resolução trata a respeito das condições, critérios e diretrizes, mínimas, exigidas, no licenciamento ambiental dos aterros sanitários de pequeno porte, que são:

Tabela 3 - Condições, critérios e diretrizes, mínimas, exigidas, no licenciamento ambiental dos aterros sanitários de pequeno porte

a)

vias de acesso ao local com boas condições de tráfego ao longo de todo o ano, mesmo no período de chuvas intensas

b) respeito às distâncias mínimas estabelecidas na legislação ambiental e normas técnicas respeito às distâncias mínimas estabelecidas na legislação ambiental relativas a áreas de

c) preservação permanente, Unidades de Conservação, ecossistemas frágeis e recursos hídricos subterrâneos e superficiais

d) uso de áreas com características hidrogeológicas, geográficas e geotécnicas adequadas ao uso pretendido, comprovadas por meio de estudos específicos uso de áreas que atendam a legislação municipal de uso e ocupação do solo, desde que

e) atendido o disposto no art. $5^{\circ}$ e 10 da Resolução CONAMA no 237, de 19 de dezembro de 1997, com preferência daquelas antropizadas e com potencial mínimo de incorporação à zona urbana da sede, distritos ou povoados e de baixa valorização imobiliária f) uso de áreas que garantam a implantação de empreendimentos com vida útil superior a 15 anos 


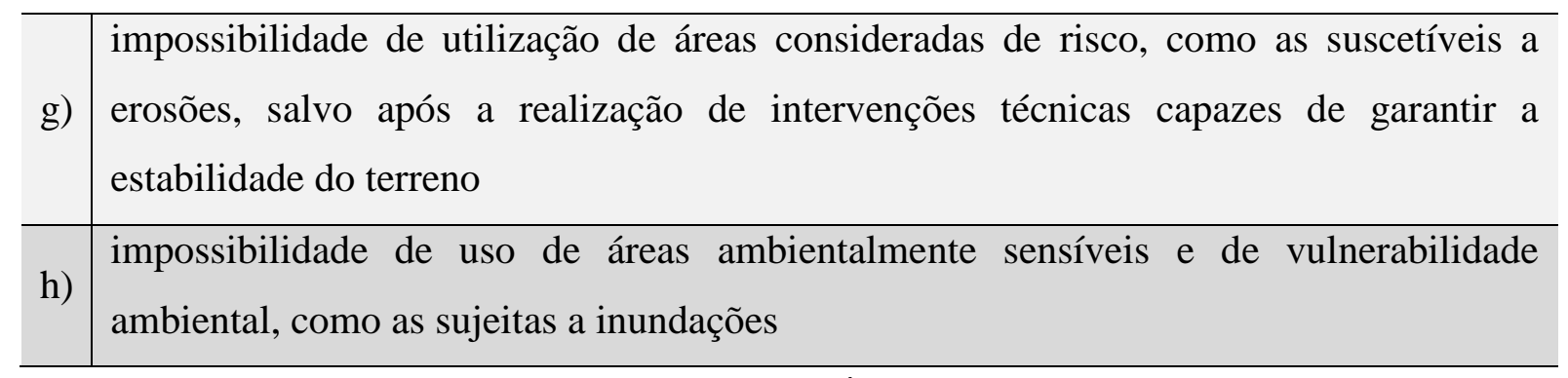

Fonte: Resolução n404/2008 - CONAMA.

\section{MATERIAIS E MÉTODOS}

A seguir são apresentados os pontos metodológicos necessários para a execução deste trabalho.

\subsection{CARACTERIZAÇÃO DA ÁREA DE ESTUDO}

O município de São João do Rio do Peixe está localizado na mesorregião do Sertão Paraibano, nas coordenadas UTM 560.954.75 m E e 9.256.209.09 m S; se estende por 473,75 km², e pertence a Bacia Hidrográfica do Rio Piancó-Piranhas-Açú, possui um clima semiárido, com vegetação do tipo caatinga hiperxerófila herbáceo-arbustiva. A sua população, conforme o último censo do Instituto Brasileiro de Geografia e Estatística (IBGE, 2010), é de 18.201 habitantes, com densidade demográfica de 38,36 $\mathrm{hab} / \mathrm{km}^{2}$.

\subsection{CRITÉRIOS PARA SELEÇÃO DAS ÁREAS DE ATERRO SANITÁRIO}

Diante da NBR 15.849:2010, a Deliberação COPAM n 4050/2019 e a Resolução CONAMA n 404/2008, para esse estudo, foram utilizados os critérios elencados na Tabela 4 para a seleção das áreas adequadas para implantação do aterro sanitário.

Tabela 4 - Critérios utilizados para a seleção das áreas de aterro sanitário

\begin{tabular}{c|c|c}
\hline Critério & Recomendado & Adotado \\
\hline $\begin{array}{c}\text { Distância mínima de corpos d'água superficiais } \\
\text { na área ou em eu entorno imediato }\end{array}$ & $200 \mathrm{~m}$ & $200 \mathrm{~m}$ \\
\hline $\begin{array}{c}\text { Distância mínima do limite da área útil do aterro } \\
\text { a núcleos populacionais vizinhos }\end{array}$ & $500 \mathrm{~m}$ & $2 \mathrm{~km}$ \\
\hline $\begin{array}{c}\text { Distância mínima da localização da área de } \\
\text { rodovias e estradas }\end{array}$ & $100 \mathrm{~m}$ & $100 \mathrm{~m}$ \\
\hline $\begin{array}{c}\text { Distância mínima de aeródromos cadastrados na } \\
\text { ANAC }\end{array}$ & $10 \mathrm{~km}$ & $10 \mathrm{~km}$ \\
\hline Vida útil previsível do aterro de pequeno porte & $>15$ anos & 20 anos \\
\hline Proximidade da zona de coleta & - & $10 \mathrm{~km}$ \\
\hline
\end{tabular}

Fonte: Autoria Própria, 2020. 
Foi admitida uma distância mínima de $2 \mathrm{~km}$ do aterro a núcleos populacionais vizinhos, tendo em vista a disponibilidade de área e a concentração da maior densidade populacional ocorrer na zona urbana da cidade, por outro lado, buscando minimizar a distância às zonas de coleta, foi adotada uma distância máxima desejável de 10 km para a localização do aterro.

\subsection{ESTIMATIVA DA ÁREA TOTAL DE DISPOSIÇÃO DE RESÍDUOS}

Para realizar a estimativa da área para disposição dos resíduos foi necessário definir o horizonte de projeto e estimar a população da área de estudo para o ano horizonte. De acordo com Santos e Girardi (2007), a Equação 1 é utilizada para esse cálculo:

$$
P o p(f)=P(i) *(1+d)^{t}
$$

Onde:

$P(i)$ é a população atual;

$d$ é a taxa de crescimento anual (supondo-se uma projeção aritmética); e

$t$ é o tempo em anos.

A população atual da cidade, de acordo com o IBGE, é de 18.201 habitantes, com uma taxa de crescimento de $3 \%$ desde 2000, e uma estimativa de taxa de crescimento anual de 0,3\%. Foram adotados dados do censo 2010 como base para ao cálculo, valor que difere em apenas 167 habitantes da estimativa do IBGE para o ano de 2019.

De acordo com a ABRELPE (2018), a geração per capita de resíduos sólidos urbanos no Nordeste do Brasil é de 0,951 kg/habitante/dia. Sabendo-se a população estimada para 2040 e a geração per capita, foi calculada a quantidade de lixo a ser produzido em 2040, conforme a Equação 2:

$$
Q(2040)=\operatorname{Pop}(2040) * 0,951
$$

Conforme Haddad (1994 apud RIBEIRO, 2011), o peso específico do lixo compactado varia entre 500 e $700 \mathrm{~kg} / \mathrm{m}^{3}$. Levando em conta a situação mais desfavorável, e sabendo a quantidade de lixo a ser produzida diariamente em 2040, o volume de resíduos produzido diariamente foi estimado pela Equação 3:

$$
V(\text { diário })=Q(2040) / 700
$$

Dessa forma, o volume total produzido até 2040 foi expresso pela Equação 4: 


$$
V(2040)=V(\text { diário }) * 365 * 20
$$

Para os cálculos realizados foram desconsiderados os processos de coleta seletiva, triagem e compostagem dos resíduos, conforme exige a Lei $n^{\circ}$ 12.305/2010, pois seria necessário a realização de um estudo in loco de classificação e quantificação dos resíduos gerados, a fim de considerar os valores reais desses processos.

A área mínima para o aterro sanitário foi definida então conforme a Equação 5, onde h é a altura máxima de empilhamento para o resíduo.

$$
A(\text { mínima })=V(2040) / h
$$

\subsection{ELABORAÇÃO DOS MAPAS TEMÁTICOS}

Na elaboração dos mapas foram utilizadas imagens do satélite LANDSAT-8, obtidas através do Serviço Geológico dos Estados Unidos (USGC), e arquivos shapfiles, de representação dos limites territoriais e sede do município, açudes, hidrografia e malha rodoviária, obtidos através do GeoPortal da Agência Executiva de Gestão das Águas do Estado da Paraíba (AESA) e do IBGE. O sistema de Coordenadas adotado foi o SIRGAS 2000, Zona 24S.

O software utilizado foi o ArcGIS versão 10.5 do Environmental Systems Research Institute (ESRI), por meio de uma análise multicritério, com a atribuição de pesos numéricos as diferentes condições existentes para os critérios aqui considerados, conforme apresentado na Tabela 5. Analisando a contribuição de cada um dos critérios adotados, foram obtidos os mapas base de uso e ocupação do solo e os de distâncias de corpos d'água, rodovias, zona urbana e aeródromos.

O município atualmente possui o Aeródromo Público de Brejo das Freiras; o mesmo é homologado

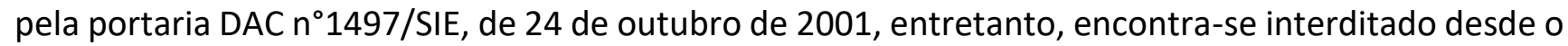
ano de 2013, conforme Ofício no 149/2013/SIA/ANAC. Tendo em vista a possibilidade de retomada do seu funcionamento durante o horizonte de projeto, foram consideradas para elaboração do mapa de áreas propícias ambas as situações, com e sem o aeródromo em funcionamento.

Os pesos atribuídos variam entre 0 a 10, sendo 0 considerado como uma área péssima para implantação do aterro, e 10 como uma área ideal. Os valores intermediários classificam as áreas entre regulares e não recomendadas. 
Tabela 5 - Classificação e pesos atribuídos aos mapas base

\begin{tabular}{c|c|c}
\hline Mapa & Classificação & Peso \\
\hline \multirow{2}{*}{ Uso e ocupação do solo } & Caatinga & 7 \\
& Solo Exposto & 10 \\
& Hidrografia & 0 \\
& Açude Pilões & 0 \\
& Açude Chupadouro & 0 \\
Distâncias de corpos d'água & São João do Rio do Peixe & 0 \\
\hline \multirow{2}{*}{ Distâncias de rodovias } & Propícia & 10 \\
& Regular & 7 \\
& Imprópria & 5 \\
\hline \multirow{2}{*}{ Distâncias de zona urbana } & Propícia & 10 \\
& Regular & 7 \\
& Péssima & 0 \\
\hline \multirow{2}{*}{ Distâncias de zona urbana com aeródromo em } & Propícia & 10 \\
funcionamento & Regular & 7 \\
& Imprópria & 5 \\
& Péssima & 0 \\
\hline & Propícia & 10 \\
& Regular & 7 \\
& Imprópria & 5 \\
& Péssima & 3 \\
\hline
\end{tabular}

Após a elaboração dos mapas base, e determinadas suas classificações com seus respectivos pesos, foi realizada a álgebra de mapas para obtenção dos mapas finais, fruto da sobreposição dos mapas base. Através do cálculo da média geométrica do peso de cada pixel, foram definidas as classes com as variações dos pesos para determinar as áreas adequadas e inadequadas a inserção do aterro sanitário.

As áreas com pesos atribuídos entre 7 a 10 foram classificadas como ideais, de 5 a 7, intermediárias, entre 3 a 5, não recomendadas, e de 0 a 3, como áreas péssimas ou improprias a implantação do aterro. Fonte: Autoria Própria, 2020.

\section{RESULTADOS E DISCUSSÕES}

A população estimada para o ano de 2040, considerando o horizonte de projeto de 20 anos e a taxa de crescimento anual de 0,3\%, foi de 19.325 habitantes (Equação 1). De posse dessa população, a quantidade de resíduos gerados foi calculada em 20.320,71 kg/dia (Equação 2). Resultando em um volume diário de $29,02 \mathrm{~m}^{3}$ (Equação 3), considerando um peso específico de $700 \mathrm{Kg} / \mathrm{m}^{3}$. 
Tendo em vista anos com 365 dias, e uma vida útil de 20 anos, o volume total de resíduos a ser disposto no aterro seria de $211.846 \mathrm{~m}^{3}$ (Equação 4). Considerando-se uma altura máxima (h) de 6 metros, sugerida por Carrilho, Candido e Souza (2018), para o empilhamento do resíduo, a área mínima calculada para o aterro sanitário é de 3,53ha (Equação 5). Tendo em vista a inserção da UGIRSU nas proximidades da área destinada a disposição dos resíduos, assim como a parte administrativa do aterro, será considerada uma área mínima de 4 hectares.

Através de imagens do satélite LANDSAT-8, sensor OLI, do dia 08 de abril de 2020, utilizando a ferramenta de Classificação de Imagens do ArcGIS, foi gerado o mapa de uso e ocupação do solo (Figura 1). De acordo com o governo do estado da Paraíba, não existem Unidades de Conservação (UCE) ou Área de Proteção Permanente (APP) no município de São João do Rio do Peixe, portanto, todas as áreas encontradas nesse mapa, exceto a sede do município e os corpos d'água, foram caracterizadas como áreas ideais a inserção do aterro, sem restrições.

Figura 1 - Mapa de uso e ocupação do solo

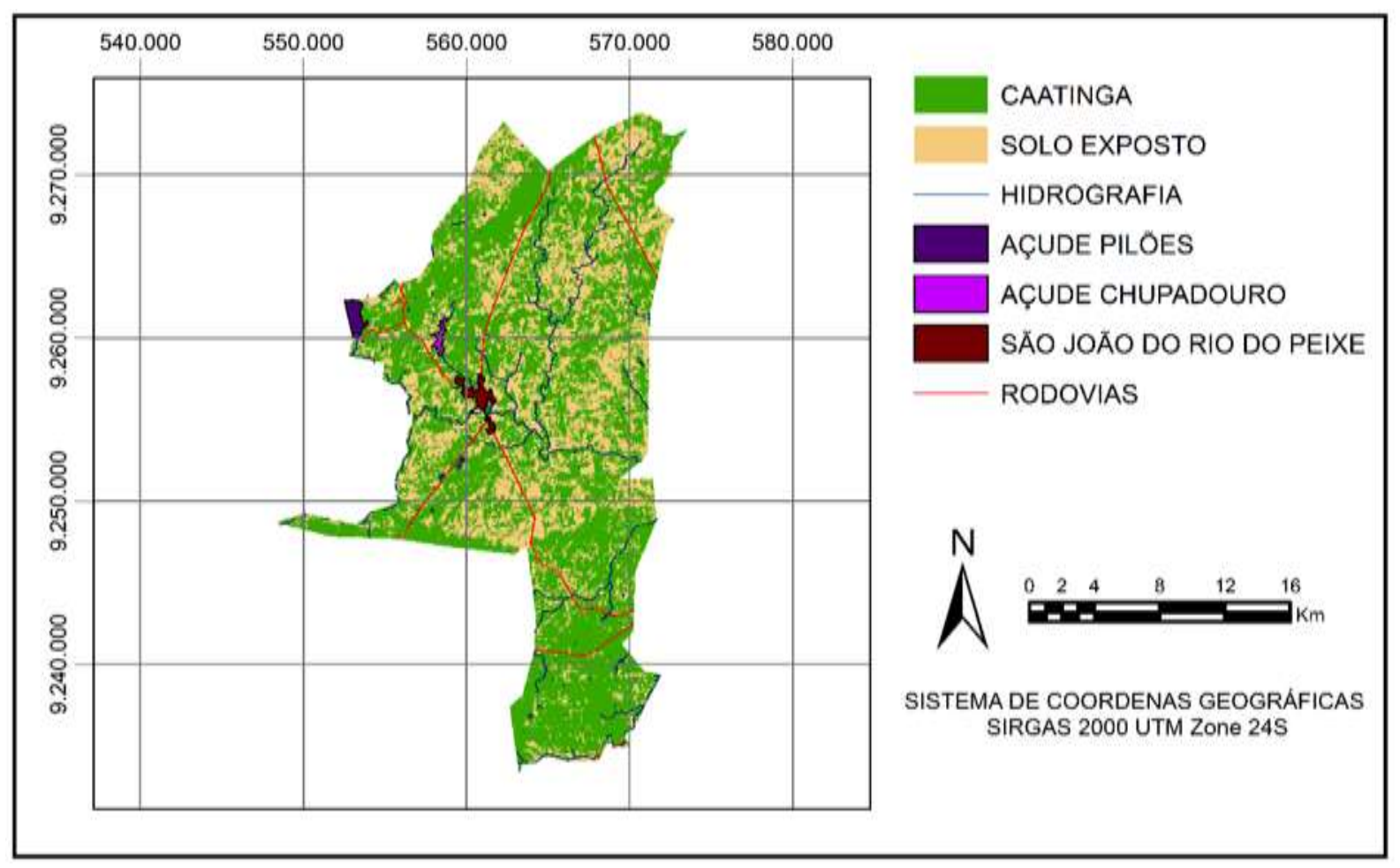

Fonte: Autoria Própria, 2020.

Para a elaboração dos demais mapas bases a seguir, foi utilizado a ferramenta buffer do ArcGIS. No mapa de distâncias de corpos d'água, foram considerados como açudagem principal o Açude de Pilões e o Açude Chupadouro por se tratarem dos dois reservatórios hídricos mais importantes do município. Apesar de serem consideradas áreas propícias aquelas que distem mais de $200 \mathrm{~m}$ dos corpos d'água, 
foi admitida uma área de aceitabilidade intermediária aquelas com distâncias entre 200 e 500m (Figura 2).

Figura 2 - Mapa de distâncias de corpos d'água

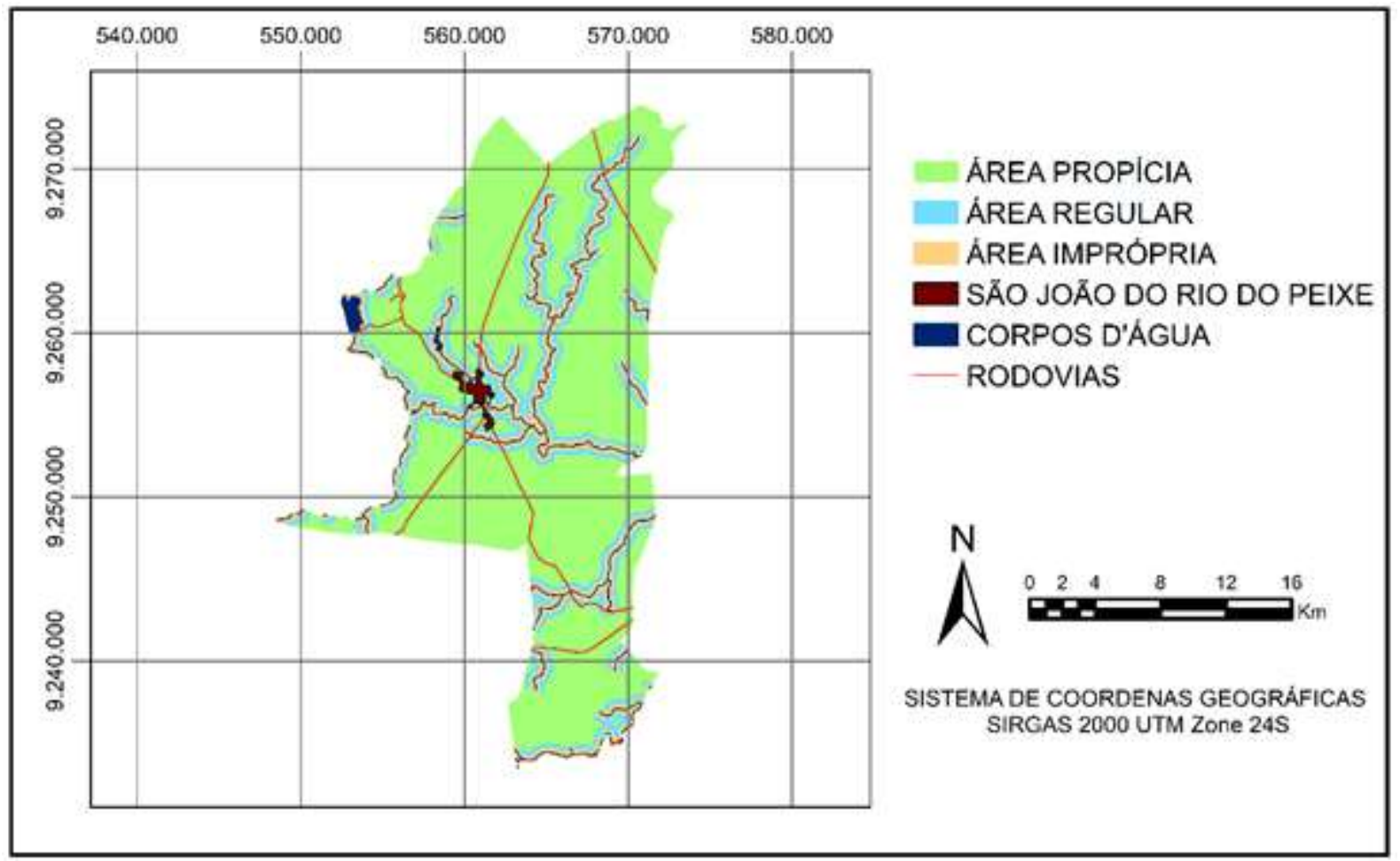

Fonte: Autoria Própria, 2020.

Na concepção do mapa de distâncias de rodovias (Figura 3), foi constatado que no município existem trechos de 5 malhas rodoviárias, que são: PB-391, PB-393, PB-395, BR-230 e BR-405. Diante dessa informação, foi considerada como área propícia, as que distam até $100 \mathrm{~m}$ da margem da rodovia, e admitida como regulares, entre 100 e $500 \mathrm{~m}$, após esse valor, foi considerada uma situação péssima, devido ao crescente distanciamento do acesso ao local da margem da rodovia. 
Figura 3 - Mapa de distâncias de rodovias

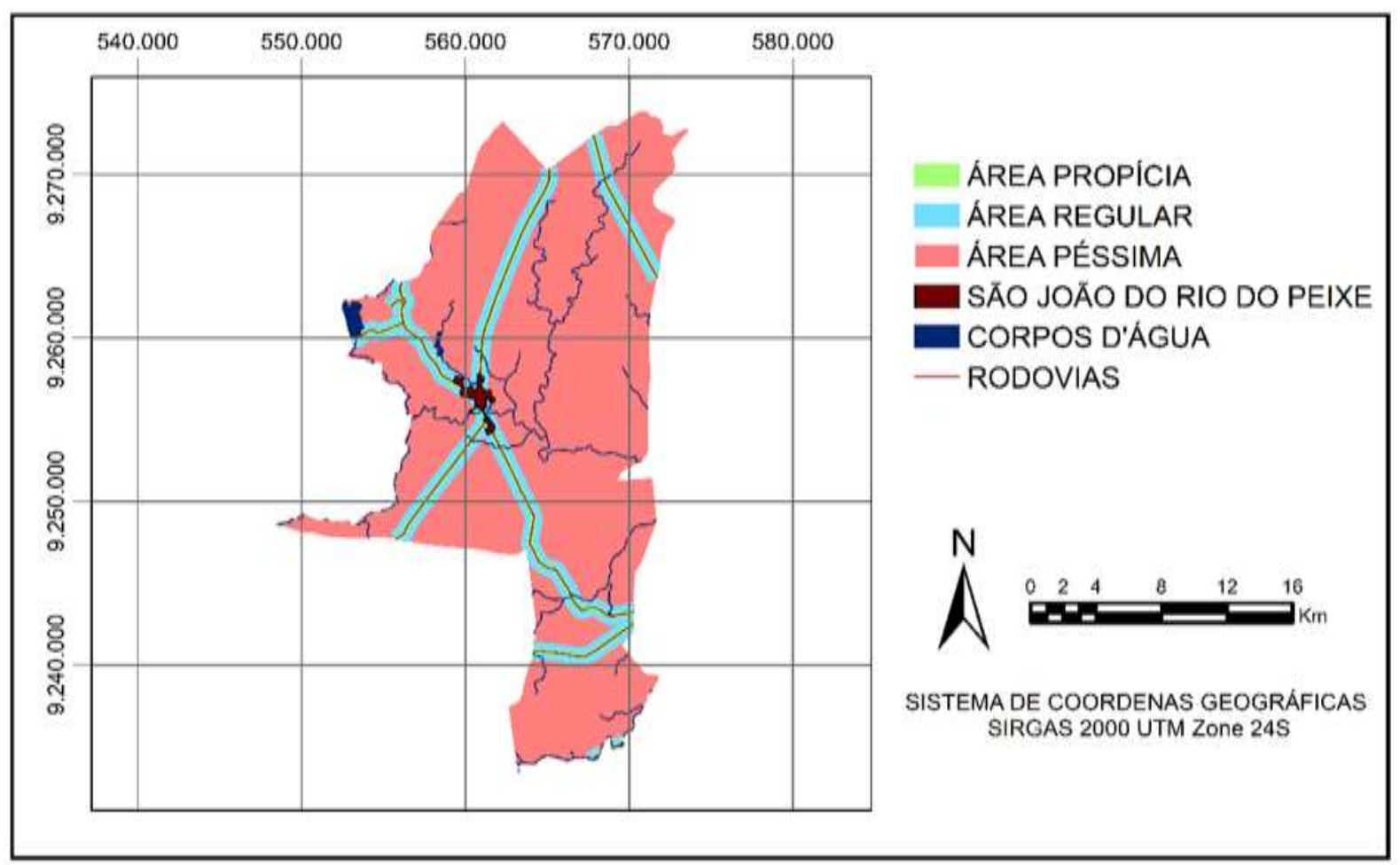

Fonte: Autoria Própria, 2020.

Para a construção do mapa de distâncias de zona urbana (Figura 4), foram adotadas 4 classificações distintas. Em um raio de $2 \mathrm{~km}$ da zona urbana, foi considerado como sendo área imprópria, devido à proximidade dos núcleos populacionais, já para as áreas que distam acima de $10 \mathrm{~km}$ da zona urbana, foi considerado como péssima, devido a distância à zona de coleta, assim áreas propícia e regular são as ideais para o funcionamento do aterro, estando o local propicio entre 5 a $10 \mathrm{~km}$ da zona urbana, e o regular entre 2 a $5 \mathrm{~km}$. 
Figura 1 - Mapa de distâncias de zona urbana

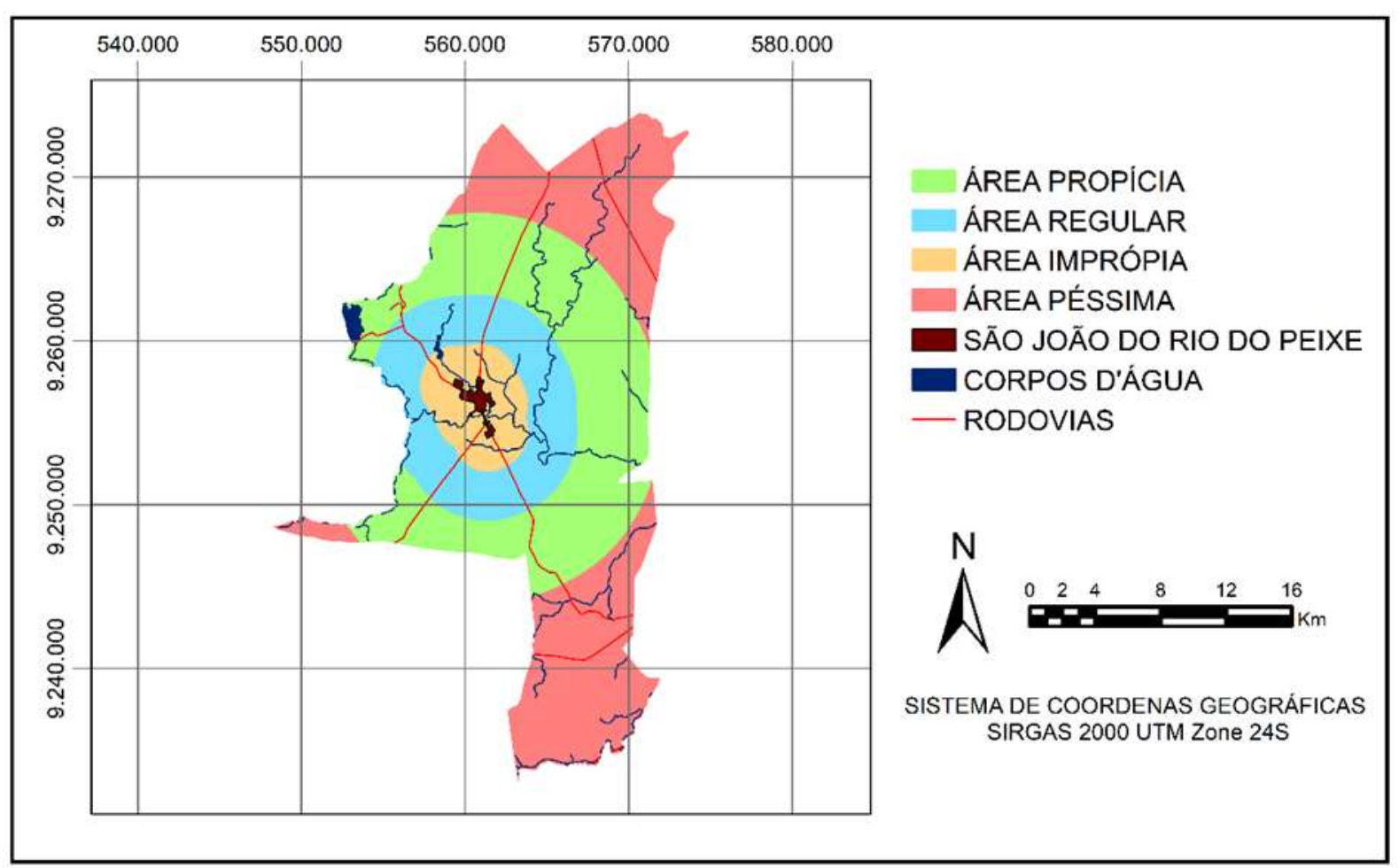

Fonte: Autoria Própria, 2020.

Vista a possibilidade de o aeródromo voltar a funcionar, durante o horizonte de projeto, foi elaborado um mapa levando em conta os mesmos critérios da Figura 4, contudo, foi acrescentada a restrição imposta para funcionamento da UGIRSU, onde é previsto um raio mínimo de $10 \mathrm{~km}$ de distância de aeródromos cadastrados na ANAC. 
Figura 2 - Mapa de distâncias de zona urbana com aeródromo em funcionamento

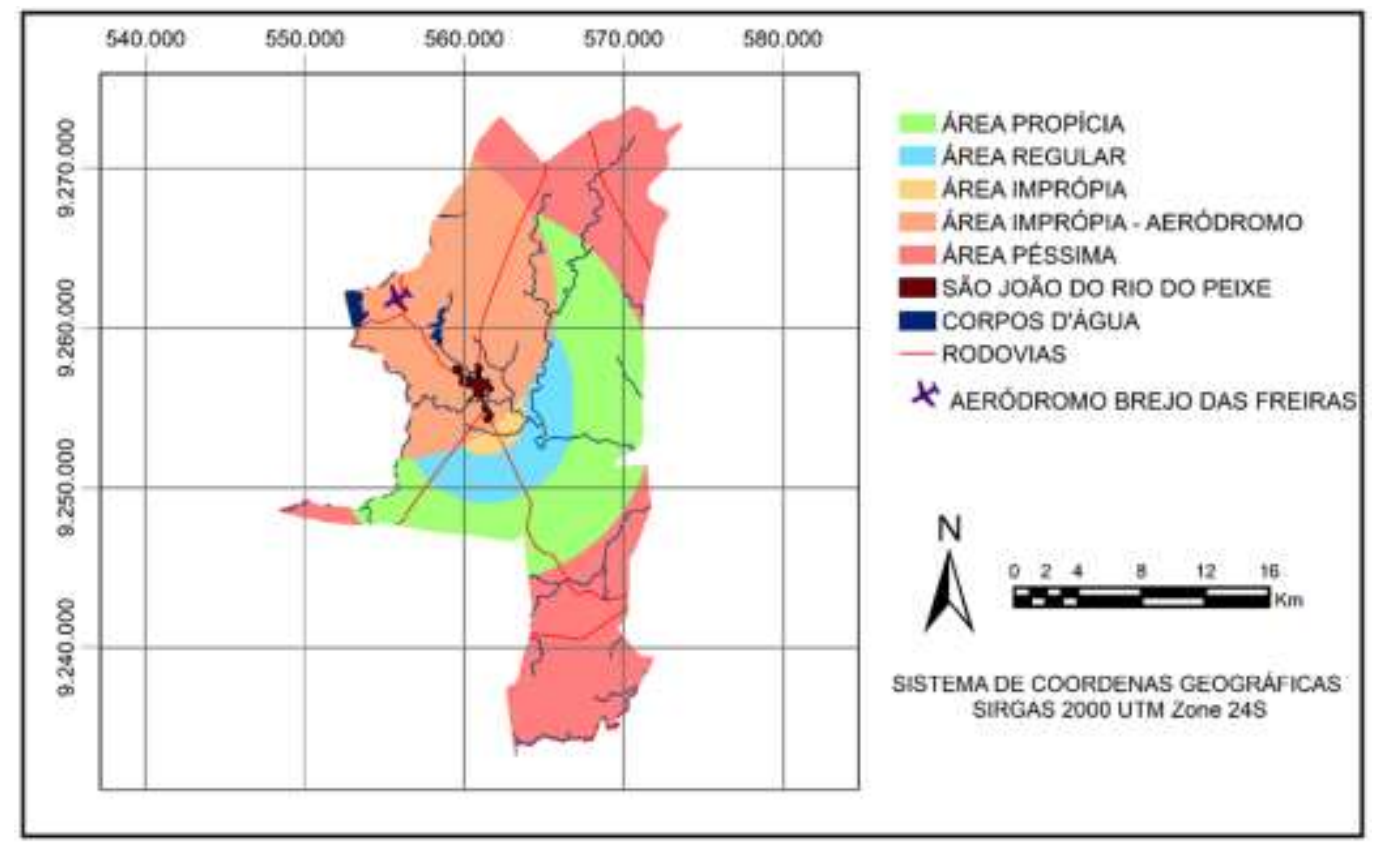

Fonte: Autoria Própria, 2020.

Por fim, após a sobreposição dos mapas temáticos apresentados nas figuras de 1 a 5 , foi gerado o mapa de áreas adequadas e inadequadas para a implantação do aterro sanitário para a situação atual, sem o aeródromo operante (Figura 6), e considerando a hipótese de o mesmo voltar as suas atividades normais, durante o horizonte de projeto (Figura 7).

As áreas propicias foram consideradas como os locais adequados ou ideais a implantação do aterro sanitário de pequeno porte, já as áreas regulares, são espaços aceitáveis a instalação do mesmo; territórios classificados como indesejáveis, são setores não recomendados, e áreas caracterizadas como péssimas, são locais ignoráveis e inadequados a instalação do aterro.

Tabela 4 - Valores representativos dos mapas finais de acordo com sua classificação

\begin{tabular}{c|c|c}
\hline Mapa & Classificação & $\mathbf{( \% )}$ \\
\hline Áreas adequadas e inadequadas para a implantação de & Propícia & 1,39 \\
aterro sanitário de pequeno porte em São João do Rio & Regular & 4,85 \\
do Peixe-PB & Indesejável & 37,89 \\
& Péssima & 55,87 \\
\hline Áreas adequadas e inadequadas para a implantação de & Propícia & 0,63 \\
aterro sanitário de pequeno porte em São João do Rio & Regular & 2,47 \\
do Peixe-PB com aeródromo em funcionamento & Indesejável & 25,34 \\
& Péssima & 71,56 \\
\hline
\end{tabular}

Fonte: Autoria Própria, 2020. 
Figura 6 - Mapa de áreas adequadas e inadequadas para a implantação de aterro sanitário de pequeno porte em São João do Rio do Peixe-PB sem o aeródromo em funcionamento

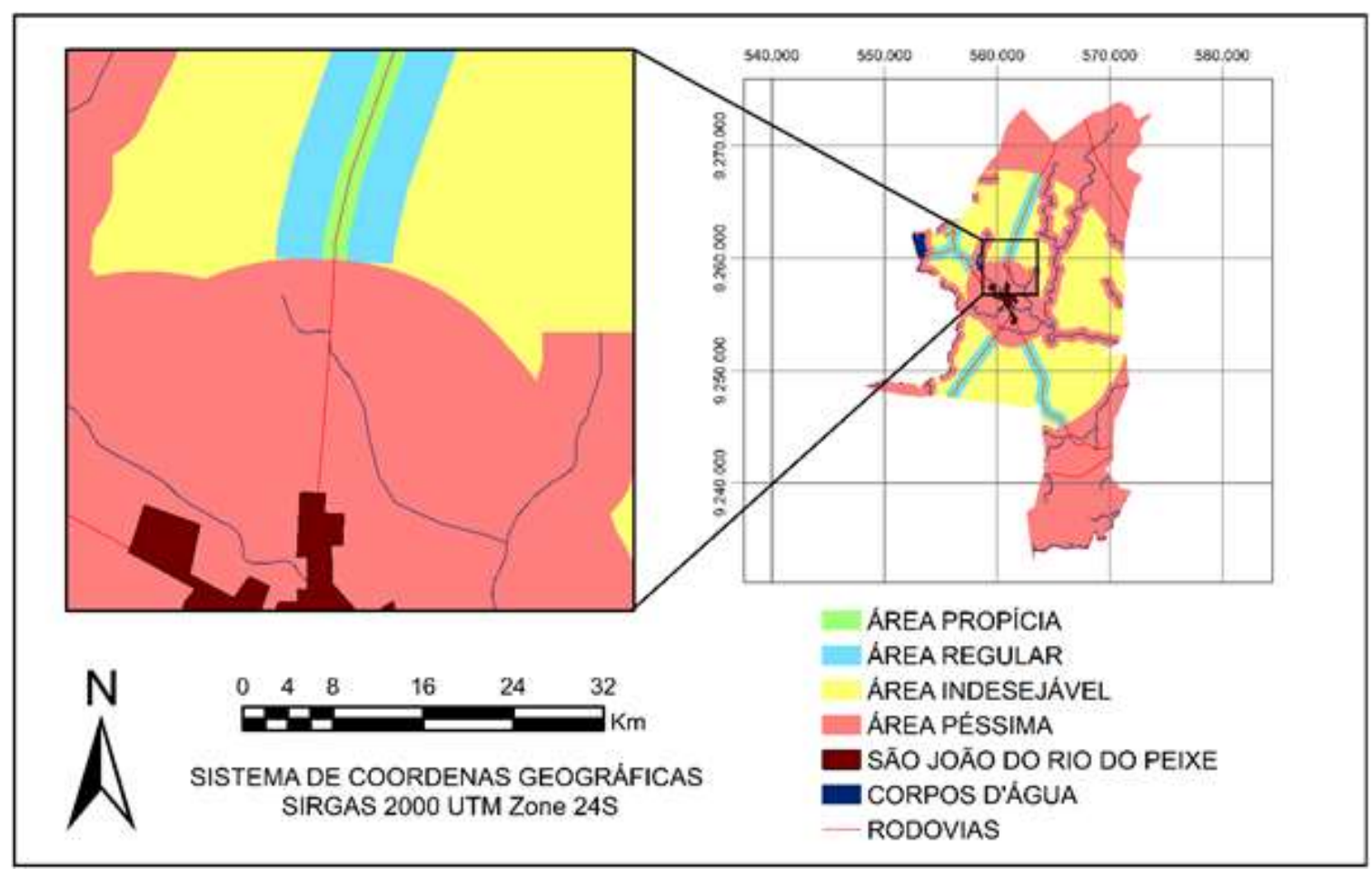

Fonte: Autoria Própria, 2020.

Figura 7 - Mapa de áreas adequadas e inadequadas para a implantação de aterro sanitário de pequeno porte em São João do Rio do Peixe-PB com o aeródromo em funcionamento

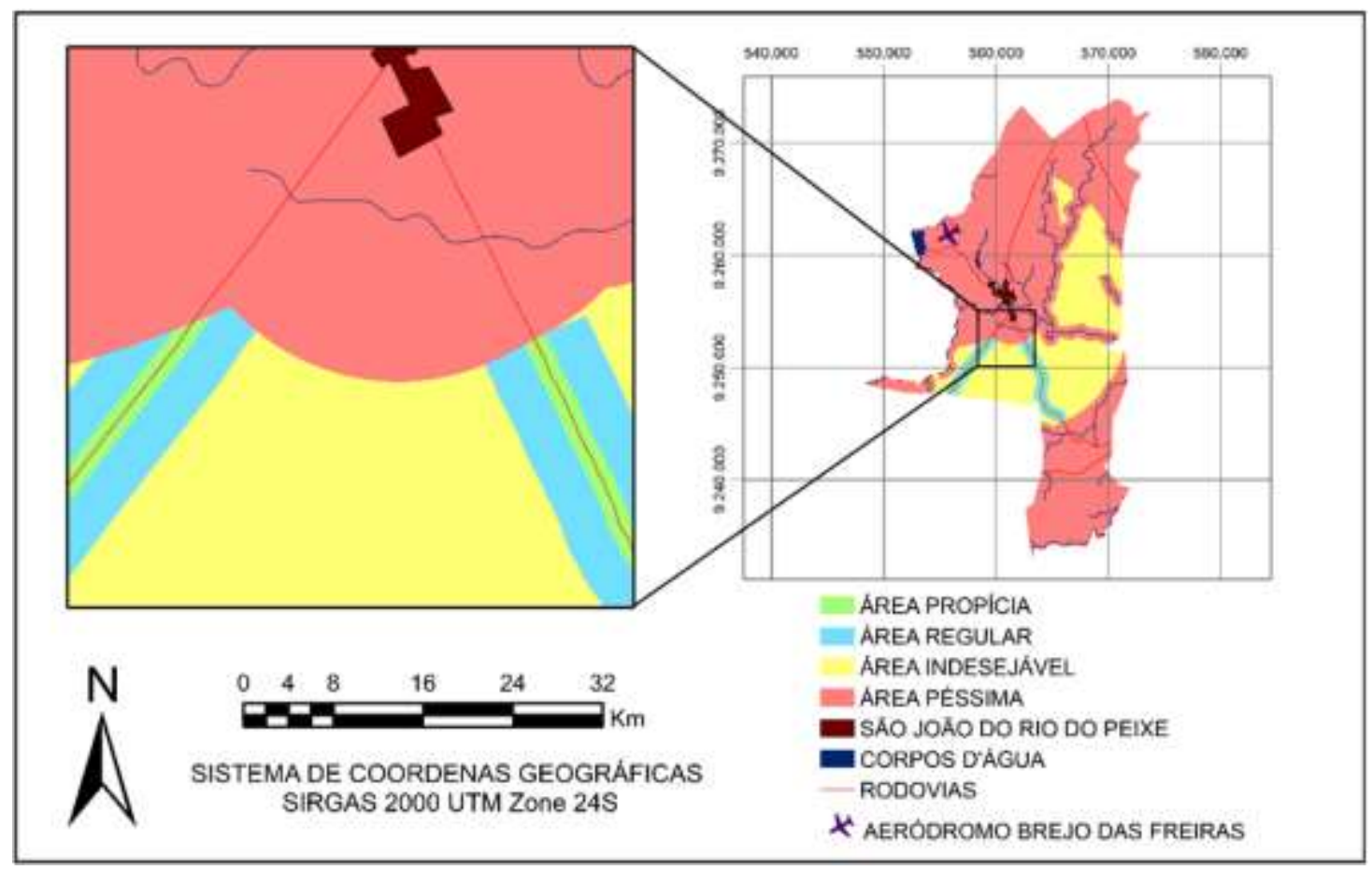

Fonte: Autoria Própria, 2020. 


\section{CONCLUSÃO}

Através do geoprocessamento, em consonância com a análise multicritério, a busca por uma área ambientalmente adequada, para a inserção do aterro sanitário de pequeno porte, foi reduzida de aproximadamente $474 \mathrm{~km}^{2}$ para $29,6 \mathrm{~km}^{2}$, no mapa de áreas adequadas e inadequadas sem o aeródromo em funcionamento; já para o mapa de áreas adequadas e inadequadas com o aeródromo em funcionamento, foi reduzida para $14,6 \mathrm{~km}^{2}$, mostrando a disponibilidade de área para implantação do aterro dentro dos limites territoriais do município de São João do Rio do Peixe, Paraíba, uma vez que a área mínima necessária seria de apenas $0,04 \mathrm{~km}^{2}$. Dessa maneira, as ferramentas de geoprocessamento se mostraram eficazes e cumpridoras do intuito deste trabalho, definindo as melhores áreas de forma técnica, garantindo a preservação do meio ambiente e a proteção à saúde pública.

Tendo em vista que o objetivo deste trabalho se restringe apenas a utilização de ferramentas de geoprocessamento para os critérios elencados na Tabela 4, é necessário que estudos detalhados sobre: geologia, geomorfologia, hidrogeologia, pedologia e topografia sejam realizados nas áreas preliminares escolhidas; para assim, atender as demais exigências normativas e definir qual a área mais adequada para inserção do aterro. 


\section{REFERÊNCIAS}

ASSOCIAÇÃO BRASILEIRA DE EMPRESAS DE LIMPEZA PÚBLICA E RESÍDUOS ESPECIAIS-ABRELPE. Panorama dos resíduos sólidos no Brasil 2018/2019. São Paulo: ABRELPE, 2019.

ASSOCIAÇÃO BRASILEIRA DE NORMAS TÉCNICAS. NBR 15849: Resíduos sólidos urbanos - Aterros sanitários de pequeno porte - Diretrizes para localização, projeto, implantação, operação e encerramento. Rio de Janeiro: ABNT, 2010.

BRASIL. Lei no 12.305, de 2 de agosto de 2010. Institui a Política Nacional de Resíduos Sólidos. Diário Oficial da União, Brasília, DF, 2010. Disponível em: http://www.planalto.gov.br/ccivil_03/_Ato20072010/2010/Lei/L12305.htm. Acesso em: 17 nov. 2020.

BRASIL. Lei no 14.026, de 15 de julho de 2020. Atualiza o marco legal do saneamento básico. Diário Oficial da União, Brasília, DF, 2020. Disponível em: http://www.planalto.gov.br/ccivil_03/_ato20192022/2020/lei/L14026.htm. Acesso em: 17 nov. 2020.

BRASIL. CONSELHO NACIONAL DO MEIO AMBIENTE-CONAMA. Resolução CONAMA no 404, de 11 de novembro de 2008. Brasília, DF, 2008. Disponível em:

http://www2.mma.gov.br/port/conama/legiabre.cfm?codlegi=592. Acesso em: 27 mar. 2020.

CONSELHO DE PROTEÇÃO AMBIENTAL-COPAM. Deliberação $n^{\circ}$ 4050, 11 de novembro de 2019. João Pessoa, PB, 2019. Disponível em:

file:///C:/Users/usuario/Downloads/Deliberacao_4050_ALTERACO_DA_NA_101_UTC_1_ULTIMA_VE RSO..pdf. Acesso em: 27 mar. 2020.

CARRILHO, A. N.; CANDIDO, H. G.; SOUZA, A. D. Geoprocessamento aplicado na seleção de áreas para a implantação de aterro sanitário no município de Conceição das Alagoas (MG). Associação Brasileira de Engenharia Sanitária e Ambiental, v. 23, n. 1, jan/fev 2018, 201-206.

INSTITUTO BRASILEIRO DE GEOGRAFIA E ESTATÍSTICA-IBGE. Cidades. Disponível em: https://cidades.ibge.gov.br/brasil/pb/sao-joao-do-rio-do-peixe/panorama. Acesso em: 27 mar. 2020.

MINISTÉRIO PÚBLICO DA PARAÍBA-MPPB. 146 prefeitos assinaram acordo com o MPPB para fechar lixões em municípios paraibanos., 17 janeiro 2020. Disponível em: http://www.mppb.mp.br/index.php/home/pgjb/38-noticias/procuradoria-geral/21940-em-um ano146-prefeitos-assinam-acordo-com-mppb-para-fechar-lixoes. Acesso em: 27 mar. 2020.

POAGUE, K. I. H. M.; SILVA, W. R.; REZENDE, V. M.; PEREIRA, A. P. M. P.; ÁRABE, M. P. SIG na seleção de áreas para implantação de aterros sanitários: estudo de caso em Jundiaí - SP. Revista DAE, núm. 213, vol. 66, outubro a dezembro de 2018.

RIBEIRO, V. V. P. Aplicação de sistema de informação geográfica na identificação de área para aterro sanitário. 2011. Dissertação (Mestrado em Ciência e Sistema de Informação Geográfica) - Centro de Informação Geográfico, Universidade Católica de Moçambique, Beira, Moçambique, 2011. 
SANTOS, J. S.; GIRARDI, A. G. Utilização de geoprocessamento para localização de áreas para aterro sanitário no município de Alegrete-RS. In: SIMPÓSIO BRASILEIRO DE SENSORIAMENTO REMOTO, Florianópolis, p. 5491-5498, 2007.

SOUZA, Sônia. Geoprocessamento aplicado à identificação de áreas potenciais à degradação da qualidade da água. 2008. Monografia (Especialização em Geoprocessamento), Departamento de Cartografia - Instituto de Geociências, Universidade Federal de Minas Gerais (UFMG), Belo Horizonte, 2008. 


\section{Capítulo 5}

doi) $10.37423 / 210704415$

\section{AVALIAÇÃO DE IMPACTOS AMBIENTAIS CAUSADOS PELA LAGOA DE ESTABILIZAÇÃO NO BAIRRO VILA NOVA II, NA CIDADE DE CAJAZEIRAS/PB}

Álisson Alberto Pinto Tôrres

Nayanne Maria Gonçalves Leite

Guilherme Rodrigues Gomes

Millena Dayse Barbosa da Silva

Luan Alves Furtado

Cinthya Santos da Silva
Instituto Federal de Educação, Ciência e

Tecnologia da Paraíba - Campus Cajazeiras

Universidade Federal de Campina Grande Campus Sumé

Universidade Federal de Campina Grande Campus Sumé

Instituto Federal de Educação, Ciência e

Techologia da Paraíba - Campus Cajazeiras

Instituto Federal de Educaçâo, Ciência e

Tecnologia da Paraíba - Campus Cajazeiras

Instituto Federal de Educação, Ciência e

Tecnologia da Paraíba - Campus Cajazeiras 
Resumo: O sistema de lagoa estabilização constitui uma forma simples para o tratamento dos esgotos, devido sua fácil implantação e baixo custo de operação, em comparação com outros sistemas de tratamento. No entanto, é necessária a avaliação dos impactos ambientais originados devido a existência da mesma, para que medidas mitigadoras, ou compensatórias, possam ser previstas para minimização de possíveis impactos negativos. Portanto, escolheu-se para realização desse estudo, a lagoa de estabilização no bairro Vila Nova II da cidade de Cajazeiras/PB. Para isso foi aplicado um checklist, onde foram elencadas algumas atividades geradoras de impacto sobre o meio antrópico e físico, e sua categorização por meio de atributos selecionados. Verificou-se uma série de problemas decorrentes da operação da lagoa facultativa, como maus odores, possível contaminação de corpos aquáticos superficiais e subterrâneos, além de contaminação do ar e do solo e a proliferação de mosquitos, bem como manutenção e operação com falhas. Dos impactos gerados, $73 \%$ foram classificados como negativos e $27 \%$ como positivos, logo, se mostra necessária a adoção de medidas de mitigação de emergência para redução dos impactos causados pela operação da lagoa no bairro.

Palavras-Chave: Impactos ambientais; Lagoa de estabilização; Checklist. 


\section{INTRODUÇÃO}

O saneamento é entendido como direito humano fundamental e, portanto, como serviço público que deve ter alcance universal (BRASIL, 2009). O Brasil, por meio dos governos atuantes, elaborou o Plano Nacional de Saneamento Básico (PLANSAB), fundamentado com base na Lei Federal no 11.445 (BRASIL, 2007). O objetivo do PLANSAB é universalizar os serviços de saneamento e abastecimento de água, tendo como previsão, em um dos cenários levantados pelo plano, um investimento da ordem de $\mathrm{R} \$ 357$ bilhões no período entre 2019- 2033 (PLANSAB, 2019). Entretanto, todo e qualquer investimento na execução de obras de saneamento, ainda que benéficas, podem causar impactos em diferentes âmbitos da sociedade, a exemplo de ambientais, sociais e econômicos (SILVA FILHO; COSTA; SILVA, 2019).

Uma das metas do PLANSAB trata da cobertura do sistema de tratamento dos esgotos coletados, onde é previsto um alcance de 93\% para o Brasil no ano de 2033 (PLANSAB, 2019). Para tanto, a implantação e adequação de Estações de Tratamento de Esgoto (ETE) são atividades necessárias, e que não devem ser dissociadas da análise dos impactos positivos e negativos oriundos da tecnologia de tratamento adotada.

Na região Nordeste as lagoas de estabilização são frequentemente utilizadas para tratamento de esgoto doméstico e industrial, tendo como principal objetivo a remoção de matéria orgânica (SABESP, 2009). Muitas vezes, porém, a lagoa está localizada em área urbanizada, e a análise da sua influência no entorno, durante sua operação, é superficial e/ou inexistente.

Apesar das inúmeras vantagens apresentadas pelos sistemas de lagoas de estabilização, como baixo custo, consumo energético nulo, simples de ser construída e operada, não necessitando de componentes importados, tendo elevada estabilização da matéria orgânica, ainda sim, existem impactos negativos oriundos das suas fases de implantação, manutenção e operação (MENDONÇA; MENDONÇA, 2018). O odor, a desvalorização econômica de imóveis e o lançamento de efluentes nos corpos d'água, são alguns dos exemplos de impactos negativos que as ETEs podem provocar no ambiente físico e socioeconômico (SILVA, 2007). Quando construídas próximas das áreas urbanizadas, podem ser observadas, ainda, repercussões da sua operação nas comunidades vizinhas, tanto de forma positiva, quanto negativa; a exemplo da propagação de maus odores, um dos principais motivos das reclamações das ETEs, e que está diretamente relacionado com a qualidade de vida dos moradores próximos, uma vez que os gases odorantes - oriundos de misturas complexas de moléculas com 
enxofre,nitrogenadas, fenóis, aldeídos, álcoois e ácidos orgânicos (BELLI FILHO et al., 2001) - podem levar a estresses psicológicos, perda de apetite, insônias, entre outros fatores (BRENNAN, 1993).

Na cidade de Cajazeiras, interior do Estado da Paraíba, a Companhia de Água e Esgotos da Paraíba (CAGEPA), usa um sistema de tratamento composto por uma lagoa facultativa, precedida de tratamento preliminar. Esta, porém, está localizada em área próxima da zona urbana da cidade.

Portanto, diante do exposto, o bairro Vila Nova Il da cidade de Cajazeiras/PB foi escolhido como objeto de estudo para realização desse trabalho, com o objetivo de identificar os impactos na ênfase ambiental causados pela existência da lagoa facultativa.

\section{REFERENCIAL TEÓRICO}

Em uma estação de tratamento de esgoto, quanto mais anaeróbio for o processo de tratamento, mais compostos odorantes serão formados (SILVA, 2007). E apesar da suma importância de um sistema de tratamento de esgotos, por meio de lagoa de estabilização ou, por lodo ativados ou tratamento anaeróbios, com o objetivo de melhorar as condições sanitárias da população, problemas associados à existência dos sistemas são comuns (SILVA, 2007). Não devendo ser negligenciados a significância dos impactos gerados, como ambientais, socioeconômicos e de saúde pública, devido à presença da ETE, na região onde ela está inserida. Para as lagoas de estabilização a necessidade de grandes terrenos, é uma das maiores desvantagens existentes, quando da sua implantação, não apenas pelo valor financeiro, mas pela

disponibilidade do mesmo (MENDONÇA; MENDONÇA, 2018).

Por outro lado, o sistema de tratamento de esgotos com lodos ativados ou lagoas aeradas, baseado numa sequência de processos bioquímicos para a separação dos sólidos suspensos e eliminação de elementos patógenos, tem entre suas desvantagens o alto custo de implantação e operação, com alta taxa de consumo energético, além da necessidade de operadores especializados e de componentes importados (MENDONÇA, MENDONÇA, 2018).

Demonstra-se na tabela 1 o consumo de energia anual para vários tipos de tratamento: 
Tabela 1 - Consumo de energia em processos distintos de tratamento

\begin{tabular}{cc}
\hline Processo de tratamento & Consumo de energia $(\mathbf{k W h} / \mathbf{a n o})$ \\
\hline Lodos ativados & 1.000 .000 \\
Lagoas aeradas & 800.000 \\
Lagoas de estabilização & zero \\
\hline
\end{tabular}

Fonte: Adaptada de Mendonça (2018)

Caracteriza-se o consumo energético nulo em lagoas de estabilização, sendo uma vantagem em relação ao tipo aeradas e lodos ativados, além do baixo custo e a simplicidade de serem construídas e operadas.

Entre os tipos de lagoas de estabilização utilizadas no tratamento de efluentes, encontra-se a alternativa da lagoa facultativa, esta funciona, em seu maior tempo, por meio da ação de algas e bactérias com influência da luz solar e da fotossíntese, como demonstra a Figura 1. As lagoas facultativas se caracterizam por possuir uma zona aeróbia superior e uma zona anaeróbia no fundo. A camada intermediária entre essas duas zonas é a facultativa, na qual predominam os processos de oxidação aeróbia e fotossintética. Estas lagoas são de dois tipos: lagoas facultativas primárias, que recebem esgoto bruto (após gradeamento e remoção de areia), e lagoas facultativas secundárias, que recebem os efluentes da fase primária (geralmente os efluentes das lagoas anaeróbias) (JORDÃO e PESSOA, 2014).

Figura 1 - Processos Biológicos

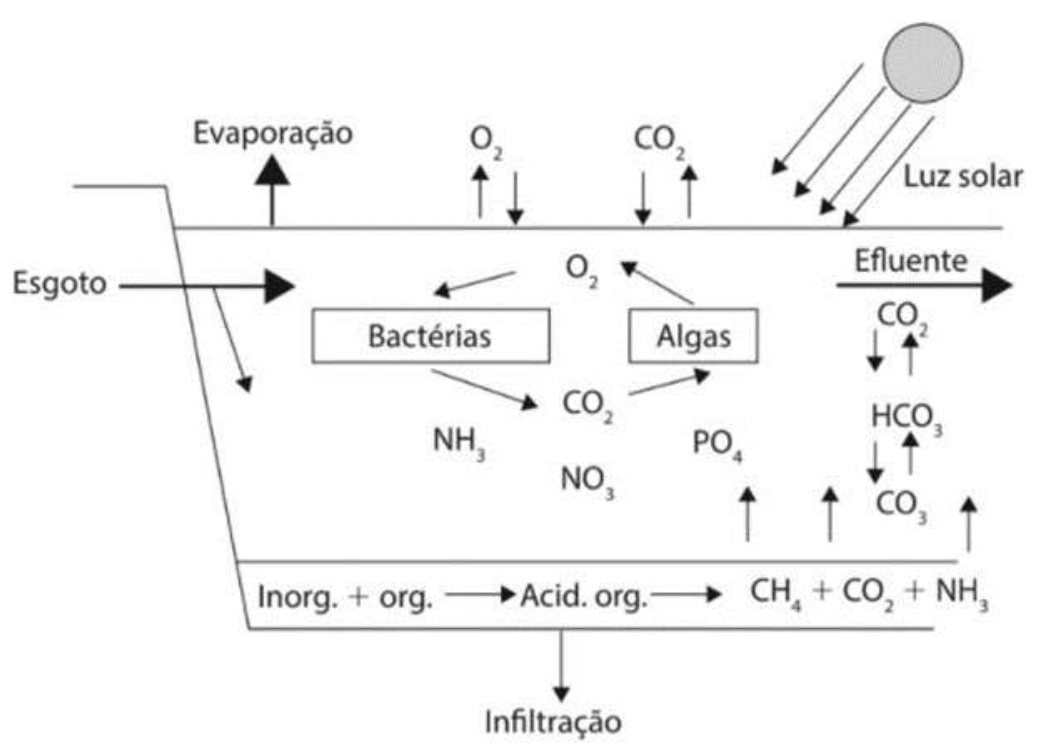

Fonte: Mendonça (2018) 
Segundo Lins (2010), para a implantação de uma lagoa de estabilização devem ser levadas em consideração as características do terreno, localização do lençol freático, taxa de percolação, e características do solo para se evitar a contaminação. Um dos principais aspectos ambientais a ser considerado é a questão da proliferação de insetos, principalmente de mosquitos em áreas de doenças endêmicas como dengue, febre amarela e malária. Para que isso não ocorra, é importante que não haja vegetação muito perto da lagoa (LA ROVERE, 2002).

\section{MÉTODO DA PESQUISA}

Neste trabalho a área de estudo compreende a ETE (Figura 2), tipo lagoa facultativa, que possui 5,4 hectares de área superficial e 1,5 metros de profundidade, localizada a leste no bairro Vila Nova II, na cidade de Cajazeiras, interior do estado da Paraíba. A cidade de Cajazeiras-PB possui aproximadamente $566 \mathrm{~km}^{2}$ e população de 61993 habitantes, sendo o sétimo município mais populoso do estado (IBGE, 2010).

Figura 2 - Localização da cidade de Cajazeiras na Paraíba

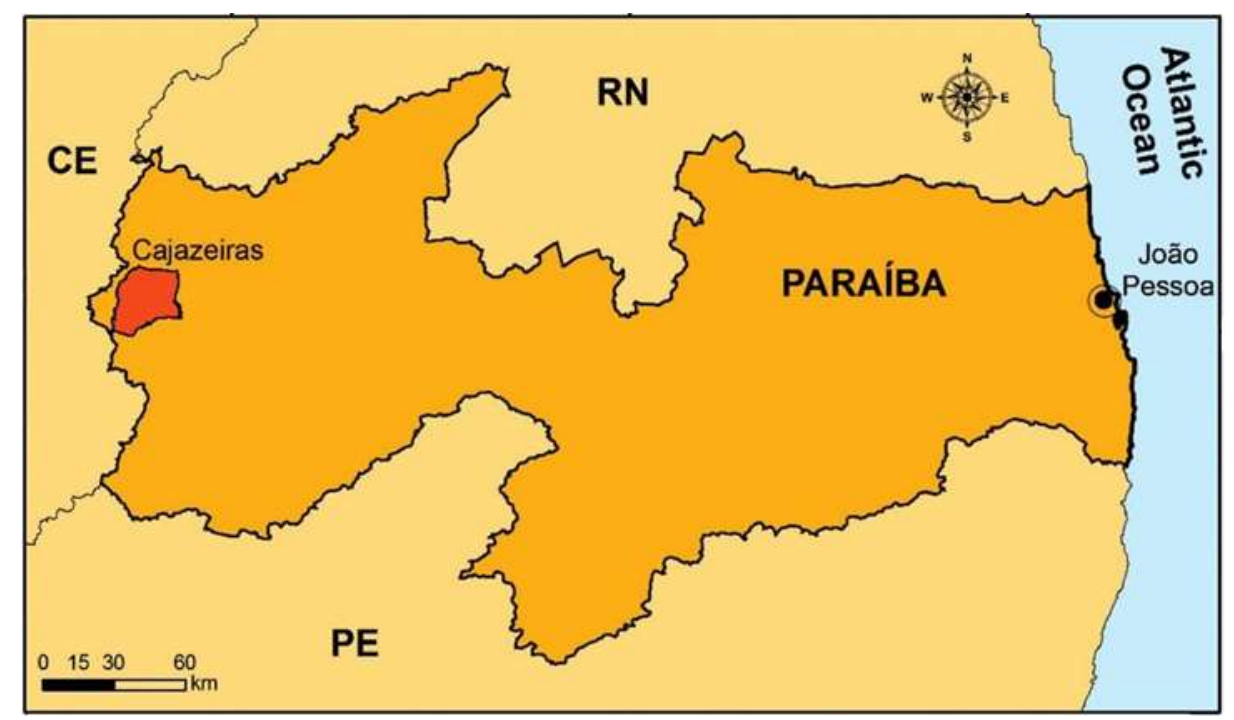

Fonte: Adaptada do Laboratório de Geomorfologia da UFRN, Campus Caicó (2019) 
Figura 3 - Lagoa de Estabilização

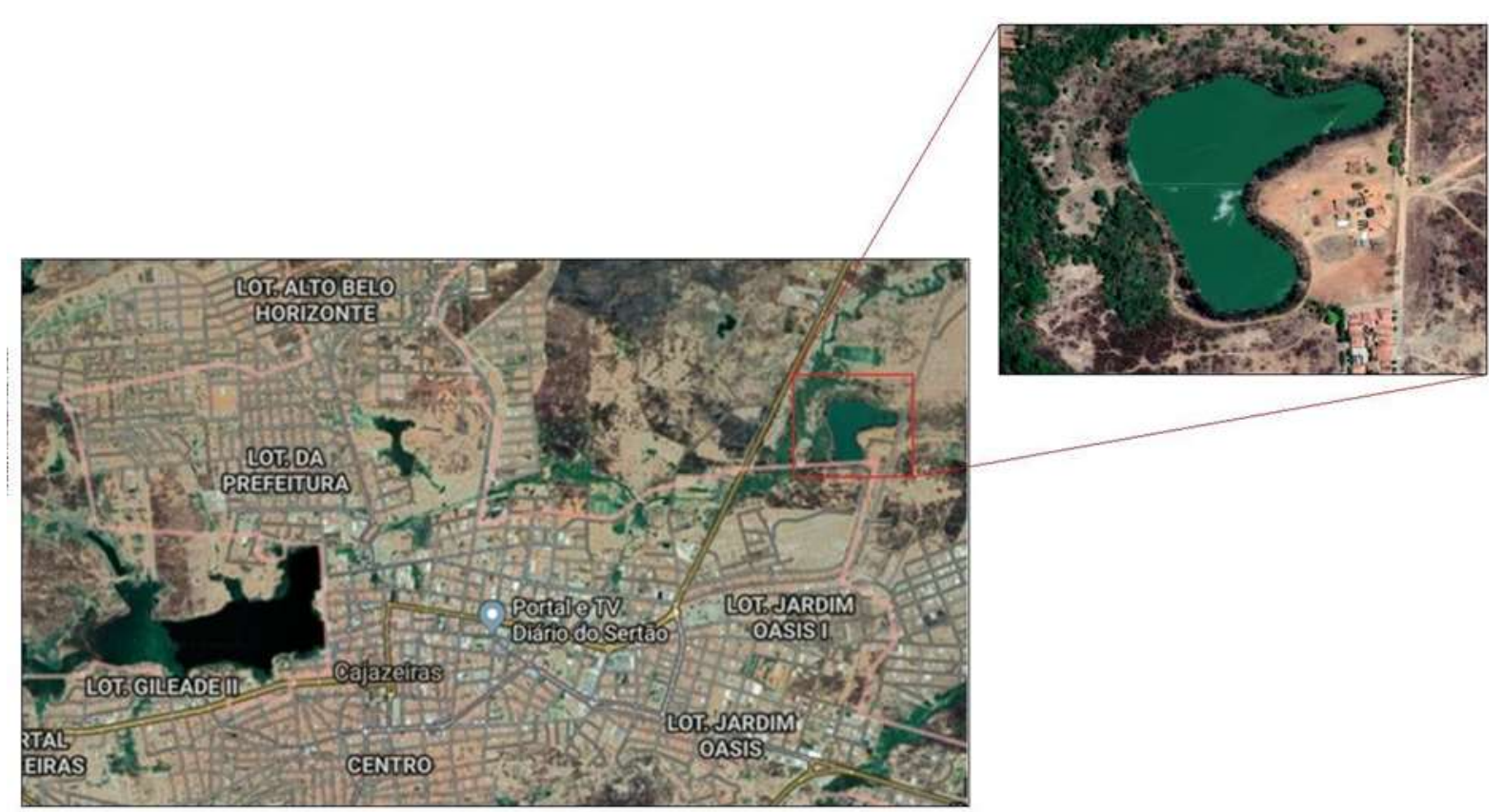

Fonte: Adaptada do Google Earth (2020)

Diante da problemática em foco, a pesquisa se deu mediante visita a localidade (ETE - Cajazeiras), onde através de registros fotográficos e observações in loco, pôde-se analisar alguns dos impactos causados pela operação da lagoa no Bairro Vila Nova - Cajazeiras/PB.

Foram analisados os impactos sobre a paisagem, o preço do $\mathrm{m}^{2}$ do bairro, a qualidade do ar, a oferta de serviços de saneamento e a geração de empregos, devido funcionamento da ETE.

Após análise das informações coletadas, pretendeu-se apontar a existência, ou não, de fatores que contribuam para a depreciação do meio físico, espaço que acomoda todos os outros meios, sustentando e dando condições para desenvolvimento de outros meios (solo, água, ar), e antrópico, tudo aquilo que resulta de ação humana, modificado pelo ser humano e, as possíveis ações mitigadoras para os impactos gerados pela Lagoa de Estabilização de Cajazeiras no Bairro Vila Nova II. Esta análise se deu por meio de Avaliação de Impacto Ambiental (AIA), sendo utilizado o método checklist, uma forma simples e de fácil interpretação. Esse método consiste na identificação, predição e avaliação dos impactos através de uma relação qualitativa de fatores e parâmetros ambientais que servem como referência.

A avaliação dos impactos ambientais foi feita apenas para a fase de operação, por meio dos atributos apresentados no quadro 1, tendo como adaptação da AIA do PROEMA para a Prefeitura de São Luís MA. 
Quadro 1 - Atributos utilizados no checklist

\begin{tabular}{|c|c|c|}
\hline ATRIBUTOS & PARÂMETROS DE AVALIAÇÃO & SÍMBOLO \\
\hline $\begin{array}{l}\text { CÁRATER } \\
\text { Expressa a alteração ou } \\
\text { modificação gerada por } \\
\text { uma ação do } \\
\text { empreendimento sobre } \\
\text { um dado componente ou } \\
\text { fator ambiental porela } \\
\text { afetado. }\end{array}$ & $\begin{array}{l}\text { BENÉFICO } \\
\text { Quando o efeito gerado for positivo } \\
\text { para o fator ambiental considerado. } \\
\text { ADVERSO } \\
\text { Quando o efeito gerado for negativo } \\
\text { para o fator ambiental considerado. }\end{array}$ & + \\
\hline $\begin{array}{l}\text { MAGNITUDE } \\
\text { Expressa a extensão do } \\
\text { impacto, na medida em } \\
\text { que se atribui uma } \\
\text { valoração gradual às } \\
\text { modificações que as } \\
\text { intervenções poderão } \\
\text { produzir num dado }\end{array}$ & $\begin{array}{l}\text { PEQUENA } \\
\text { Quando a variação no valor dos } \\
\text { indicadores for inexpressiva e não altere } \\
\text { o fator ambiental considerado. } \\
\text { MÉDIA } \\
\text { Quando a variação no valor dos } \\
\text { indicadores for expressiva, porém sem } \\
\text { alcance para descaracterizar o fator } \\
\text { ambiental considerado. }\end{array}$ & MM \\
\hline
\end{tabular}

\begin{tabular}{|l|l|l|}
\hline $\begin{array}{l}\text { componente ou fator } \\
\text { ambiental por ela } \\
\text { afetado. }\end{array}$ & $\begin{array}{l}\text { GRANDE } \\
\text { Quando a variações no valor dos } \\
\text { indicadores for de tal ordem que possa } \\
\text { levar à descaracterização do fator } \\
\text { ambiental considerado. }\end{array}$ & MG \\
\hline $\begin{array}{l}\text { REVERSIBILIDADE } \\
\text { relimita a } \\
\text { impacto ambilidade do } \\
\text { consequência da ação } \\
\text { que o gerou. }\end{array}$ & $\begin{array}{l}\text { REVERSÍVEL } \\
\text { Quando cessada a ação que o gerou a } \\
\text { alteração, o meio afetado retornará ao } \\
\text { seu estado primitivo. }\end{array}$ & $\begin{array}{l}\text { IRREVERSíVEL } \\
\text { Quando cessada a ação que o gerou a } \\
\text { alteração, o meio afetado não retornará } \\
\text { ao seu estado primitivo. }\end{array}$ \\
\hline
\end{tabular}




\begin{tabular}{|c|c|c|}
\hline $\begin{array}{l}\text { ORDEM } \\
\text { Estabelece o grau de } \\
\text { relação entre a ação } \\
\text { impactante e o impacto } \\
\text { gerado ao meio } \\
\text { ambiente. }\end{array}$ & $\begin{array}{l}\text { DIRETA } \\
\text { Resulta de uma simples relação de causa } \\
\text { e efeito, também denominado impacto } \\
\text { primário ou de primeira ordem. } \\
\text { INDIRETA } \\
\text { Quando gera uma reação secundária em } \\
\text { relação à ação ou, quando é parte de uma } \\
\text { cadeia de reações também denominada } \\
\text { de impacto secundário ou de enésima } \\
\text { ordem, de acordo com a situação na } \\
\text { cadeia de reações. }\end{array}$ & OD \\
\hline $\begin{array}{l}\text { IMPORTÂNCIA } \\
\text { Estabelece a } \\
\text { significância ou oquanto } \\
\text { cada impacto é } \\
\text { importante na sua } \\
\text { relação de interferência } \\
\text { com o meio ambiente, e } \\
\text { quando comparado a } \\
\text { outros impactos. }\end{array}$ & $\begin{array}{l}\text { NÃO SIGNIFICATIVA } \\
\text { A intensidade da interferência do } \\
\text { impacto sobre o meio ambiente e em } \\
\text { relação aos demais impactos não implica } \\
\text { em alteração da qualidade de vida. } \\
\text { MODERADA } \\
\text { A intensidade do impacto sobre o meio } \\
\text { ambiente em relação aos outros } \\
\text { impactos, assume dimensões } \\
\text { recuperáveis, } \\
\text { adverso, para a queda da qualidade de } \\
\text { vida, ou assume melhoria da qualidade } \\
\text { de vida. } \\
\text { SIGNIFICATIVA } \\
\text { A intensidade da interferência do } \\
\text { impacto sobre o meio ambiente e junto } \\
\text { aos demais impactos acarreta, como } \\
\text { resposta, } \\
\text { qualidade de vida, quando adverso, ou } \\
\text { ganho, quando benéfico. }\end{array}$ & IM \\
\hline
\end{tabular}

Fonte: Adaptada de Proema Prefeitura de São Luís -MA (2013)

\section{RESULTADOS DA PESQUISA}

\section{a. Análise de atributos}

No Quadro 2 pode-se verificar os efeitos prognosticados devido a operação da lagoa de estabilização, a caracterização dos impactos nos sistemas ambientais, bem como a avaliação dos mesmos de acordo com os atributos do Quadro 1. 
Quadro 2 - Checklist dos Impactos Ambientais

\begin{tabular}{|c|c|c|c|c|c|c|c|c|c|c|c|c|}
\hline \multirow{2}{*}{ Efeitos Prognosticados } & \multicolumn{2}{|c|}{$\begin{array}{l}\text { Sistema Ambiental } \\
\text { Impactado }\end{array}$} & \multicolumn{5}{|c|}{$\begin{array}{c}\text { Caracterização do Impacto } \\
\text { Meio Físico }\end{array}$} & \multicolumn{5}{|c|}{$\begin{array}{c}\text { Caracterização do Impacto } \\
\text { Meio Antrópico }\end{array}$} \\
\hline & Físico & Antrópico & $\mathbf{C}$ & $\mathbf{M}$ & $\mathbf{R}$ & $\mathbf{O}$ & $\mathbf{I}$ & $\mathbf{C}$ & $\mathbf{M}$ & $\mathbf{R}$ & $\mathbf{O}$ & I \\
\hline Contaminação do $\mathrm{Ar}$ & $\mathrm{X}$ & $\mathrm{X}$ & _ & MP & RR & OD & IS & - & MP & $\mathrm{RR}$ & OI & IS \\
\hline Contaminação do Solo & $\mathrm{X}$ & $\mathrm{X}$ & - & MM & RI & OD & IS & - & MM & RR & OI & IS \\
\hline Proliferação de Mosquitos & $\mathrm{X}$ & $\mathrm{X}$ & - & MP & RR & OD & IM & - & MP & RR & OI & IM \\
\hline Maus odores & & $\mathrm{X}$ & & & & & & - & MM & RR & OI & IS \\
\hline Geração de empregos & & $\mathrm{X}$ & & & & & & + & MG & $\mathrm{RR}$ & OD & IS \\
\hline $\begin{array}{l}\text { Riscos de acidentes com os } \\
\text { moradores }\end{array}$ & & $\mathrm{X}$ & & & & & & - & MP & RR & OD & IS \\
\hline $\begin{array}{l}\text { Riscos de quedas de } \\
\text { animais }\end{array}$ & $\mathrm{X}$ & & - & MM & RR & OD & IS & & & & & \\
\hline Qualificação Profissional & & $\mathrm{X}$ & & & & & & + & MG & RI & OD & IS \\
\hline $\begin{array}{l}\text { Riscos de contaminação de } \\
\text { lençol freáticos }\end{array}$ & $\mathrm{X}$ & $\mathrm{X}$ & - & MM & RR & OD & IS & - & MM & RR & OI & IS \\
\hline $\begin{array}{l}\text { Riscos de contaminação de } \\
\text { corpos aquáticos } \\
\text { superficiais }\end{array}$ & $\mathrm{X}$ & $\mathrm{X}$ & - & MM & $\mathrm{RR}$ & OD & IS & - & MM & $\mathrm{RR}$ & OI & IS \\
\hline $\begin{array}{l}\text { Melhoria da qualidade de } \\
\text { vida }\end{array}$ & & $\mathrm{X}$ & & & & & & + & MM & RR & OD & IM \\
\hline $\begin{array}{l}\text { Valorização dos imóveis de } \\
\text { região do entorno }\end{array}$ & & $\mathrm{X}$ & & & & & & - & MM & $\mathrm{RR}$ & OI & IM \\
\hline $\begin{array}{l}\text { Geração de efluentes } \\
\text { líquidos }\end{array}$ & $\mathrm{X}$ & & - & MG & RR & OD & IS & & & & & \\
\hline Modificação da paisagem & & $\mathrm{X}$ & & & & & & - & MM & RR & OI & IS \\
\hline $\begin{array}{l}\text { Geração de } \\
\text { resíduos sólidos }\end{array}$ & $\mathrm{X}$ & & + & MG & RI & OD & IS & & & & & \\
\hline $\begin{array}{l}\text { Danos à saúde dos } \\
\text { operadores }\end{array}$ & & $\mathrm{X}$ & & & & & & - & MG & $\mathrm{RI}$ & OD & IS \\
\hline
\end{tabular}

Fonte: Adaptada de Proema Prefeitura São Luís - MA (2013)

Foram identificados 8 impactos exclusivamente sobre o meio físico, 13 sobre o meio antrópico e 5 que impactam de forma direta sobre o meio físico, mas geram impactos secundários no meio antrópico (Figura 3), a exemplo da contaminação do lençol freático que atinge o solo e a água, além da saúde humana, que pode utilizar a água para consumo próprio. 
Figura 4 - Quantificação dos impactos por sistema

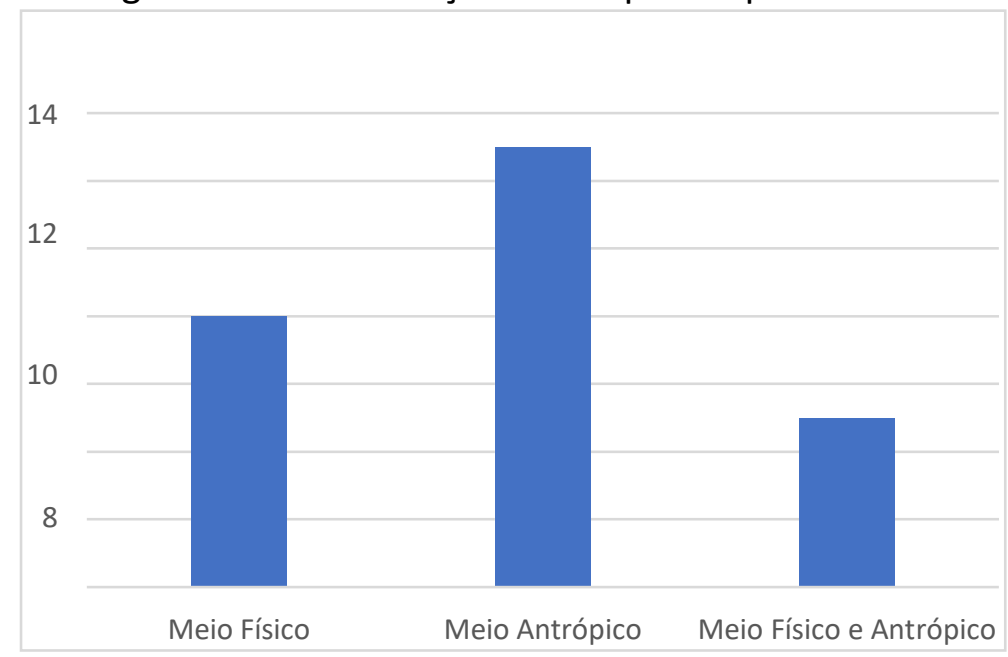

Fonte: Autoria Própria (2020)

Sabe-se ainda, que com relação ao atributo caráter, $73 \%$ dos impactos gerados são negativos, destacando-se a contaminação de corpos aquáticos superficiais e subterrâneos, além de maus odores, contaminação do ar e do solo, proliferação de mosquitos. O meio físico foi impactado de forma direta e o meio antrópico de forma indireta, principalmente através dos surgimentos de riscos à saúde humana. Por outro lado, $27 \%$ são positivos, como a geração de empregos, a destinação adequada dos resíduos sólidos e a melhoria da qualidade de vida da população (Figura 4).

Figura 5 - Percentual dos impactos em relação ao atributo caráter

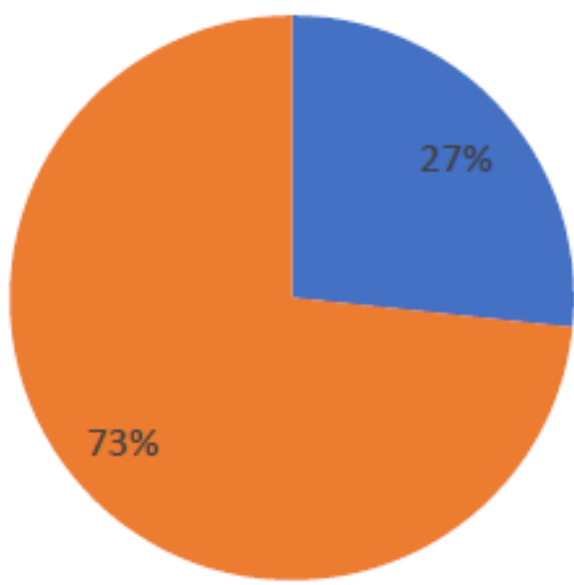

— POSITIVO nEGATIVO

Fonte: Autoria Própria (2020) 
Dentre os impactos negativos do tratamento de esgotos, a propagação de maus odores, é um dos principais motivos das reclamações das ETEs, que geralmente está relacionada com pH elevados, principalmente quando existe a presença de lagoas anaeróbias e/ou a falta de manutenção adequada do sistema, sendo que estes fatores na maioria das vezes seriam de simples correção (SILVA FILHO; COSTA; SILVA, 2019).

Na ETE Cajazeiras/PB, há apenas presença de lagoa facultativa com formato pouco usual, onde podem ser identificados possíveis pontos de ocorrência de odores na formação de zonas mortas localizadas próxima a margem, destacados na Figura 5.

Figura 6 - Entrada e saída de efluente e acúmulo de algas

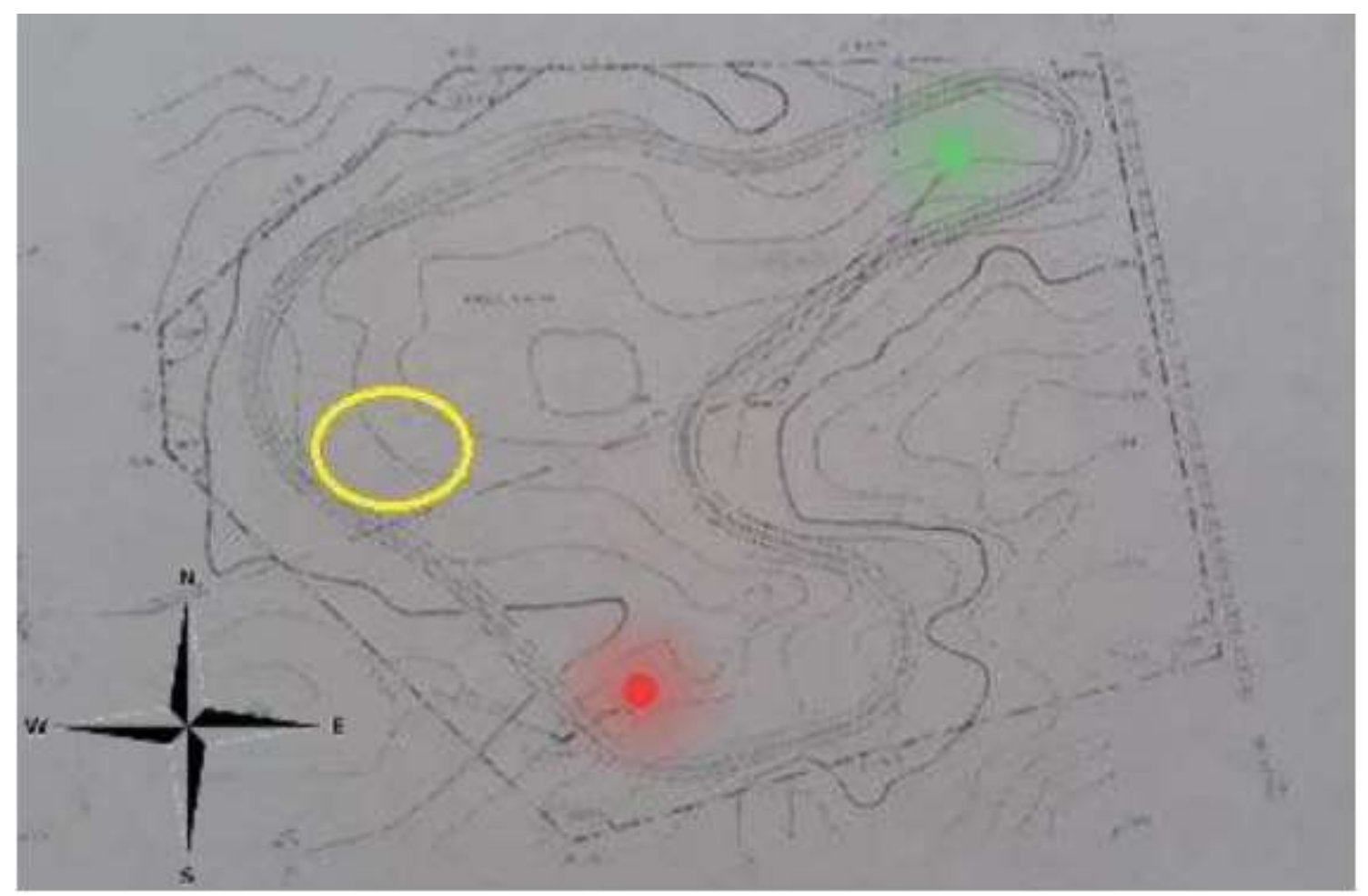

Fonte: Adaptada da CAGEPA (2018)

Como a direção dos ventos predominante em Cajazeiras é no sentido sudeste e o formato da lagoa é irregular, é favorecido o acúmulo de algas em uma pequena extensão como é demostrado na marcação em amarelo na Figura 6. Com o tempo essa concentração de algas aumenta até atingir a saturação, como não há remoção de imediato, as algas mais velhas morrem e uma crosta de lodo vai se formar na superfície (Figura 7), impedindo a troca de oxigênio entre o ar e o meio líquido, instalando-se assim o processo anaeróbio com geração de mau odor. 
Figura 7 - Acúmulo de alga

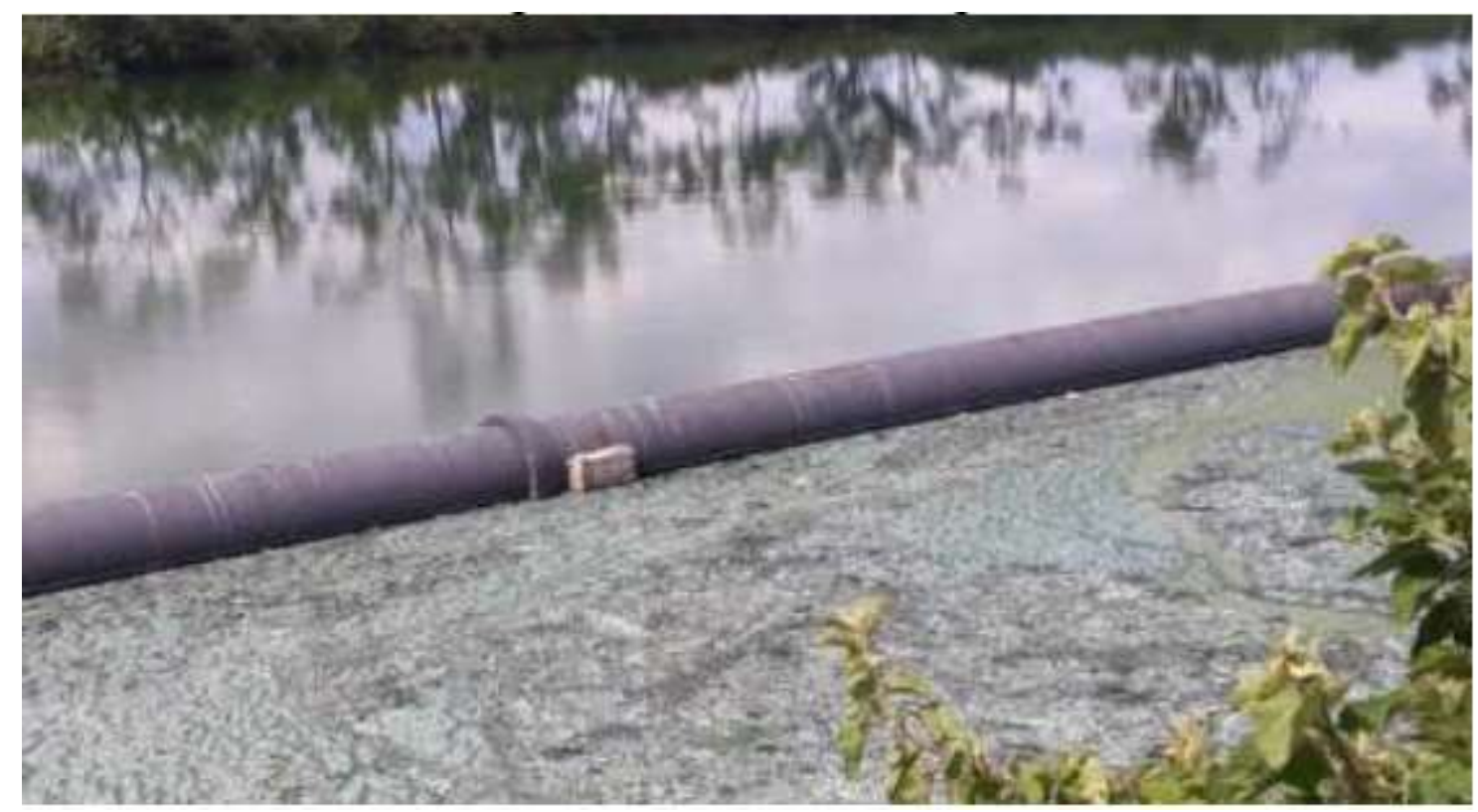

Fonte: Autoria Própria (2020)

Foi observada também a presença de plantas no talude interno da lagoa (Figura 7), prática não recomendada, por favorecer o crescimento de mosquitos e outros insetos causadores de doenças como febre amarela, dengue e malária, conforme referenciado neste trabalho.

Figura 8 - Presença de vegetação no talude

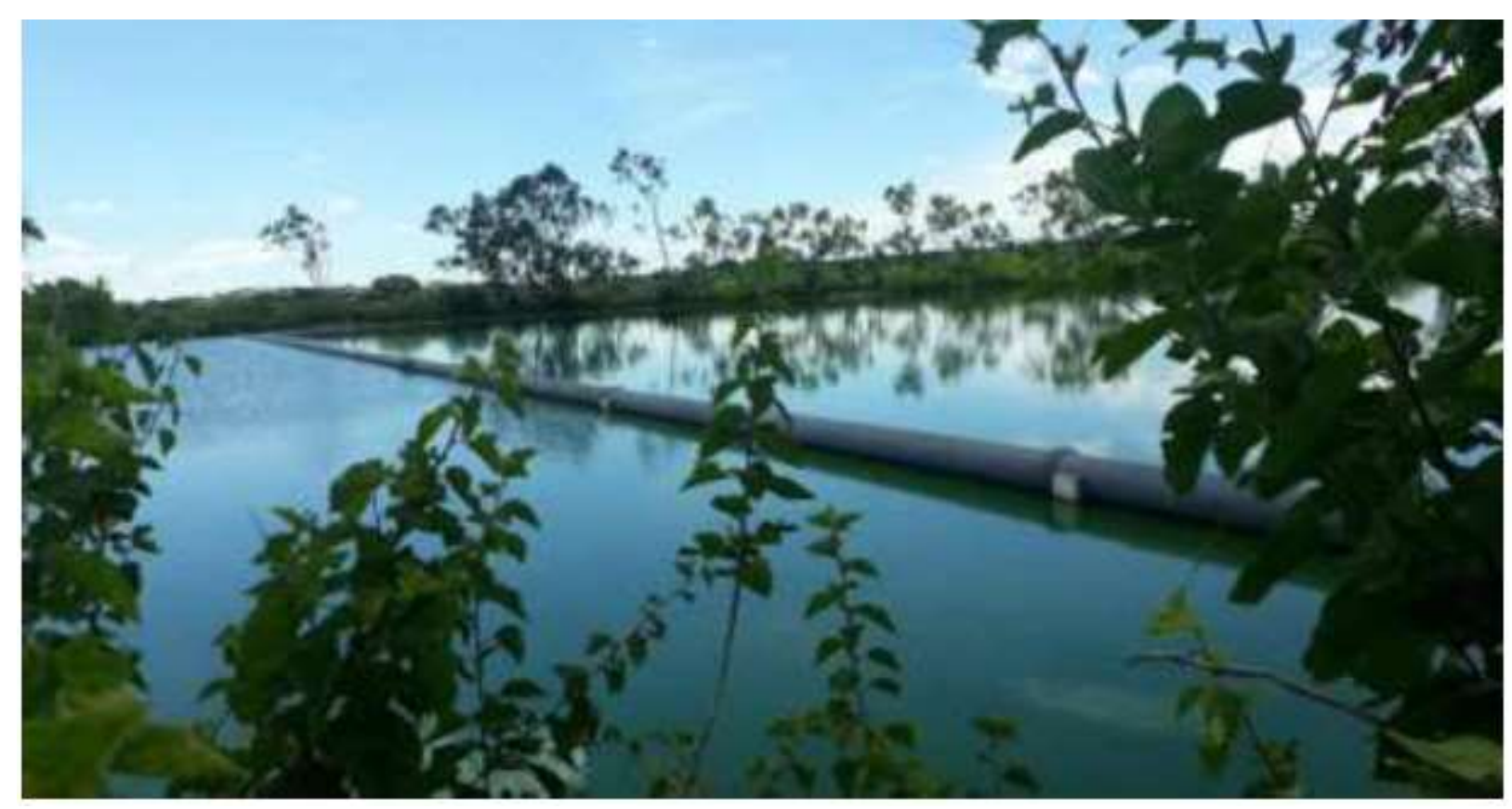

Fonte: Autoria Própria (2020) 
Com relação ao tubo instalado no meio da Lagoa de Estabilização (Figuras 6 e 7), sua existência também favorece a formação de uma extensa zona morta ou de estagnação, pois a parte inferior do tubo fica submersa impedindo a passagem do sobrenadante em direção ao vertedouro de saída.

Outra problemática observada é a proximidade das residências em relação a Lagoa, ficando a uma distância aproximada de 90m, além do acesso à mesma ser bastante fácil, pois está apenas cercada por estacas de concreto com arame farpado, ainda sim, deteriorado em parte, ficando uma abertura que possibilita a entrada de qualquer pessoa ou animal.

Quanto a desvalorização dos imóveis de região do entorno, não verificou-se depreciação, exceto as residências já existentes ao lado da lagoa, segundo informações fornecidas por imobiliárias da cidade, pois o Loteamento Jardim América, situado à $250 \mathrm{~m}$ da lagoa de estabilização tem terrenos com faixas de preço entre $\mathrm{R} \$ 200,00$ a $\mathrm{R} \$ 250,00$ por metro quadrado, valor equivalente ao Loteamento Luar Campos Universitário (bairro popular), localizado na zona norte de Cajazeiras-PB, que tem terrenos com faixas de preço de $\mathrm{R} \$ 150,00$ a $\mathrm{R} \$ 250,00$ o metro quadrado.

b. Medidas corretivas e mitigadoras

Segundo a NTS 230 da SABESP (2009), as lagoas de estabilização devem ser construídas afastadas das áreas urbanizadas e urbanizáveis conforme planos diretores locais e, distanciadas das residências em pelo menos $400 \mathrm{~m}$, tomando-se o cuidado de o vento não soprar no sentido lagoa-comunidade na maior parte do tempo, e que seja transversal ao sentindo do escoamento do efluente. O formato deve ser de preferência retangular com o lado maior coincidindo com a direção do fluxo do esgoto e evitar a formação de áreas sem circulação (áreas mortas).

Logo, atenta-se que existiu um planejamento inadequado por parte da Prefeitura Municipal de Cajazeiras na liberação de residências nas redondezas da lagoa, nos anos posteriores a sua implantação e que, mesmo que o vento não flua a maior parte do tempo no sentido das residências, o acúmulo de algas e consequentemente uma zona morta, devido a forma irregular da lagoa, causa a propagação de mau odor.

Desconsiderando a hipótese de retirada da lagoa do local onde hoje se encontra, esta problemática poderia ser minimizada através de rotinas de manutenção mais eficientes. Uma manutenção com maior acuidade poderia resultar no melhoramento de todo o processo, evitando inclusive o mau odor caso haja uma rápida remoção do sobrenadante. 
É sugerido assim, um melhor acompanhamento, inclusive com a capacitação necessária dos operadores. A utilização de uma lista de itens é um instrumento importante para o operador programar suas atividades, inclusive a maior parte dos itens são de observações visuais ou de pequena manutenção. Todos os funcionários devem, ainda, ser instruídos a resolver quaisquer acidentes imediatamente, especialmente com relação ao processo do tratamento de esgoto.

Uma outra solução corretiva de maior impacto e mais onerosa seria correção do formato da Lagoa de Estabilização e realocação do tubo que atravessa a mesma.

Apesar dos problemas citados, segundo informações da concessionária responsável pela sua operação, a lagoa de estabilização de Cajazeiras-PB possui um funcionamento eficiente, buscando garantir atender parte da população. Com uma vazão diária média de 25 L/s, provenientes de aproximadamente 2.760 ligações de esgoto existentes, o efluente tratado é despejado no Rio Catolé. Embora seja uma proporção muito menor que a de abastecimento de água com 23 mil ligações, representando apenas $12 \%$ deste total, não se pode negar a importância da sua existência, mesmo diante dos possíveis impactos negativos a ela associados.

\section{CONCLUSÃO}

As lagoas de estabilização, embora sejam de grande importância para a melhoria do estado sanitário da população, geram um grande número de impactos negativos no meio ambiente, o que torna necessária a tomada de medidas mitigatórias adequadas de forma a minimizá-los posteriormente. Alguns dos sistemas afetados negativamente pela sua operação são os meios físico e antrópico, além do biológico, sendo o último não abordado neste trabalho devido à ausência de dados fornecidos pela CAGEPA em virtude da pandemia do COVID-19. Todos os impactos foram observados durante a fase de operação, e mostraram a necessidade do departamento técnico de gestão, de realizar pesquisas de rotina sobre a aplicação das medidas mitigadoras.

Apesar dos reflexos negativos, é nítida a oportunidade de melhoria social com geração de emprego e renda devido a existência da lagoa, além da oferta do serviço de saneamento, essencial para a manutenção da qualidade de vida.

Embora subjetivo, os principais efeitos positivos e negativos, oriundos de algumas das suas atividades, puderam ser identificados de forma rápida e econômica por meio do checklist. Por fim, conclui-se que a ferramenta checklist pode ser aplicada de forma concisa, organizada e compreensiva, adequando 
como prioridade os impactos mais relevantes, além de instigar a avaliação das consequências, mesmo que de forma limitada. 


\section{REFERÊNCIAS}

BELLI FILHO, Paulo, CASTILHOS JUNIOR, Armando Borges de. COSTA, Rejane. SOARES, Sebastião Roberto. PERDOMO, Carlos. Tecnologias para o tratamento de dejetos de suínos. Revista Brasileira de Engenharia Agrícola e Ambiental, [s.I.], v. 5, n. 1, p.166- 170, abr. 2001. FapUNIFESP. DOI: http://dx.doi.org/10.1590/s1415-43662001000100032.

BRASIL. Lei no. 11.445, de 05 de janeiro de 2007. Estabelece diretrizes nacionais para o saneamento básico; altera as Leis nos 6.766, de 19 de dezembro de 1979, 8.036, de 11 de maio de 1990, 8.666, de 21 de junho de 1993, 8.987, de 13 de fevereiro de 1995; revoga a Lei no 6.528, de 11 de maio de 1978; e dá outras providências. Disponível em: http://www.planalto.gov.br/ccivil_03/_ato20072010/2007/lei/l11445.htm. Acesso em: 05 fev. 2020.

BRASIL. MINISTÉRIO DAS CIDADES. Secretaria Nacional de Saneamento Ambiental. Plano Nacional de Saneamento Básico - PLANSAB - Subsídios para a definição do Projeto Estratégico de elaboração do PLANSAB, 2019. Disponível em:

http://www.agersa.ba.gov.br/wpcontent/uploads/2019/03/Versaoatualizada07mar2019_consultapu blica.pdf. Acesso em: 06 de nov. 2020.

BRASIL. MINISTÉRIO DAS CIDADES. Secretaria Nacional de Saneamento Ambiental. Programa de Modernização do Setor Saneamento (PMSS) Instrumentos das políticas e da gestão dos serviços públicos de saneamento básico / coord. Berenice de Souza Cordeiro.

- Brasília: Editora, 2009. 239p. (Lei Nacional de Saneamento Básico: perspectivas para as políticas e gestão dos serviços públicos.; v.1)

BRENNAN, B. Odour nuisance. Water and Wast Treatment, 36, 30-33. COMPANHIA DE SANEAMENTO BÁSICO DO ESTADO DE SÃO PAULO-

SABESP. NTS230: Lagos de estabilização e seu tratamento complementar para esgoto sanitário - Procedimento. Sabesp, 2009. 30 p. Disponível em:

https://www3.sabesp.com.br/normastecnicas/nts/nts230.pdf. Acesso em: 17 fev. 2020.

INSTITUTO BRASILEIRO DE GEOGRAFIA E ESTATÍ́STICA (IBGE). Censo Brasileiro de 2010 Disponível em: https://cidades.ibge.gov.br/brasil/pb/cajazeiras/panorama. Acesso em: 05 fev. 2020. 
JORDAO, Eduardo Pacheco; PESSOA, Constantino Arruda. Tratamento de Esgotos Domésticos. 7a edição. Rio de Janeiro: ABES, 2014. v. 1. 1113p.

LA ROVERE, Emilio Lebre; D'AVIGOGNON, Alexandre; Carla Valdetaro; KLIGERMAN, Débora Cynamon; SILVA, Heliana Vilela de Oliveira; BARATA, Martha Macedo de Lima; MALHEIROS, Telma Maria Marques. Manual de Auditoria Ambiental para Estações de Tratamento de Esgotos Domésticos. Rio de Janeiro. Qualitymark. 145p. 2002.

LINS, Gustavo Aveiro. Avaliação de impactos ambientais em estações de tratamento de esgotos (ETE). Rio de Janeiro, 2010. Dissertação (Mestrato em Engenharia Ambiental) - Escola Politécnica, Universidade Federal do Rio de Janeiro, Rio de Janeiro, 2010.

MENDONÇA, Sérgio Rolim; MENDONÇA, Luciana Coelho. Lagoa de

Estabilização; Sistemas sustentáveis de esgotos. 2. ed. [s. L.]: Blucher, 2018. Cap. 7. p. 221-

268. Disponível em:

https://books.google.com.br/books?id=GS1dDwAAQBAJ\&printsec=frontcover\&dq=inauthor :\%22Mendon\%C3\%A7a,+S\%C3\%A9rgio+Rolim\%22\&hl=pt-

BR\&sa=X\&ved=0ahUKEwjR7Mbq08LoAhU0IbkGHXr7DH4Q6AEIKDAA\#v=onepage\&q \&f=false. Acesso em: 17 de fev. 2020.

SILVA FILHO, Pedro Alves; COSTA, Márcia Severino; SILVA, Fabrício Leocádio; Caracterização qualitativa de impacto social, ambiental e de saúde pública da lagoa de estabilização em Boa Vista RR. In: 30 CONGRESSO BRASILEIRO DE ENGENHARIA

AMBIENTAL E SANITÁRIA, Natal - RN. p.1-7. Disponível em: http://abes.locaweb.com.br/XP/XPEasyArtigos/Site/Uploads/Evento45/TrabalhosCompletosPDF/I-041.pdf. Acesso em: 06 de nov. 2020. SILVA, Alcione Batista. Avaliação da produção de odor na estação de tratamento de esgoto Paranoá e seus problemas associados. 2007. Dissertação (Mestrado em Tecnologia Ambiental e Recursos Hídricos) - Departamento de Engenharia Civil e Ambiental , Universidade de Brasília, Brasília, DF, 111p. Disponível em: https://repositorio.unb.br/bitstream/10482/2290/1/2007_AlcioneBatistadaSilva.pdf. Acesso em: 30 de mar. 2020. 
